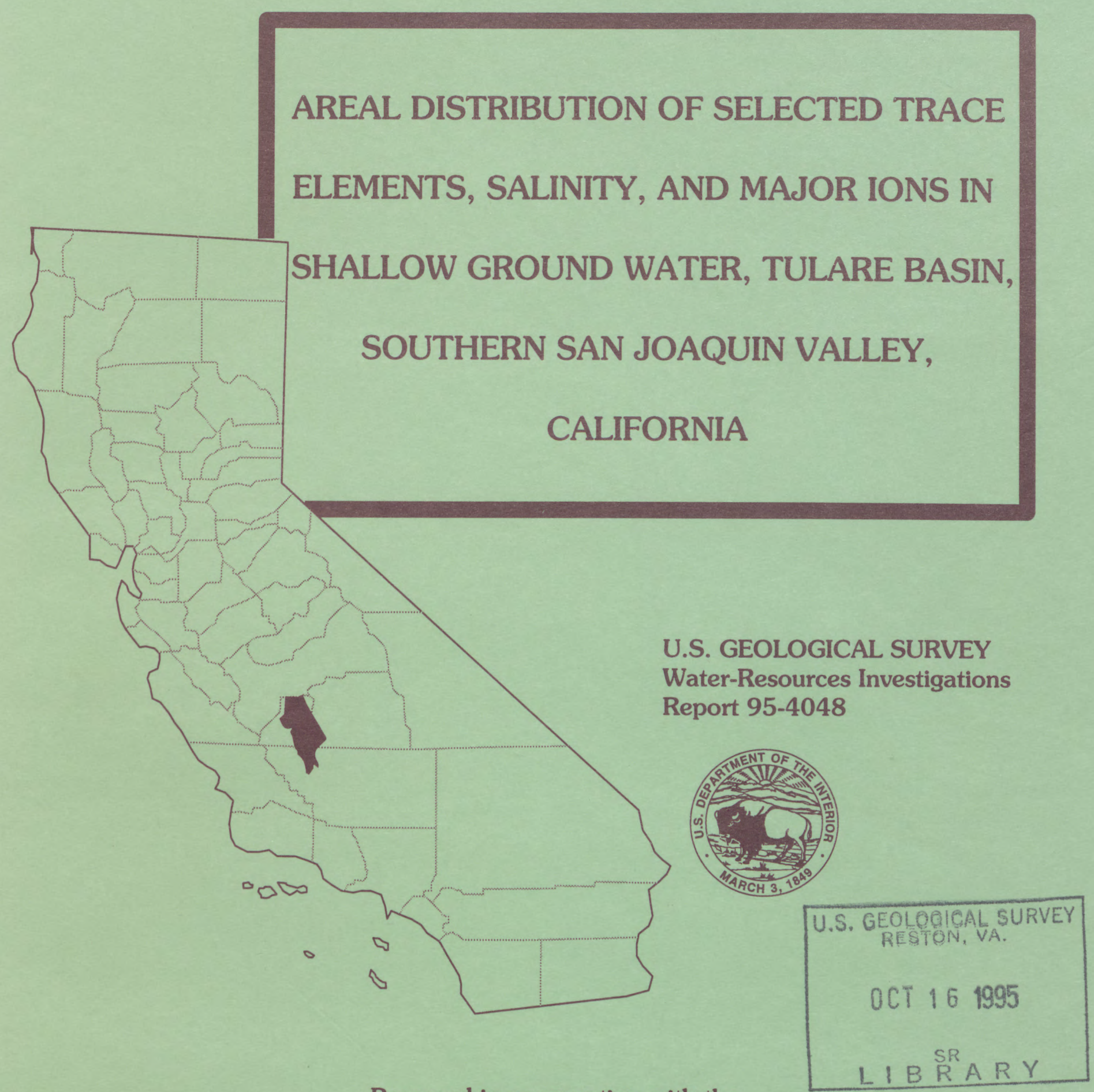

Prepared in cooperation with the CALIFORNIA DEPARTMENT OF WATER RESOURCES and the SAN JOAQUIN VALLEY DRAINAGE PROGRAM 
The San Joaquin Valley Drainage Program was established in mid-1984 and was a cooperative effort of the U.S. Bureau of Reclamation, U.S. Fish and Wildlife Service, U.S. Geological Survey, California Department of Fish and Game, and California Department of Water Resources. The purpose of the program was to investigate the problems associated with the drainage of agricultural lands in the San Joaquin Valley and to develop solutions to those problems. Consistent with these purposes, program objectives addressed the following key concerns: (1) public health, (2) surface- and ground-water resources, (3) agricultural productivity, and (4) fish and wildlife resources. These studies were completed in fiscal year 1991. 


\section{AREAL DISTRIBUTION OF SELECTED TRACE ELEMENTS, SALINITY, AND MAJOR IONS IN SHALLOW GROUND WATER, TULARE BASIN, SOUTHERN SAN JOAQUIN VALLEY, CALIFORNIA}

By Roger Fujii and Walter C. Swain

U.S. GEOLOGICAL SURVEY

Water-Resources Investigations Report 95-4048

Prepared in cooperation with the

CALIFORNIA DEPARTMENT OF WATER RESOURCES and the SAN JOAQUIN VALLEY DRAINAGE PROGRAM 


\section{U.S. DEPARTMENT OF THE INTERIOR \\ BRUCE BABBITT, Secretary}

\section{U.S. GEOLOGICAL SURVEY \\ Gordon P. Eaton, Director}

Any use of trade, product, or firm names in this publication is for descriptive purposes only and does not imply endorsement by the U.S. Government.

For sale by the

U.S. Geological Survey

Earth Science Information Center

Open-File Reports Section

Box 25286, MS 517

Denver Federal Center

Denver, CO 80225

For additional information write to:

District Chief

U.S. Geological Survey

Federal Building, Room W-2233

2800 Cottage Way

Sacramento, CA 95825 


\section{CONTENTS}

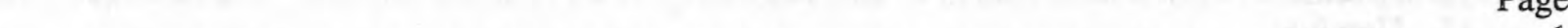

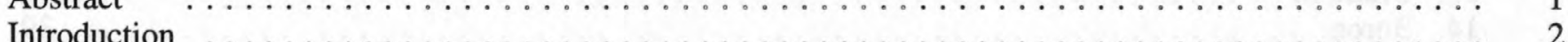

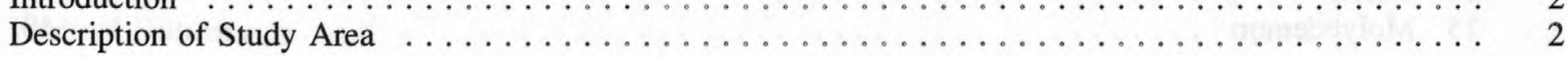

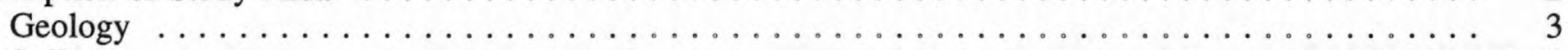

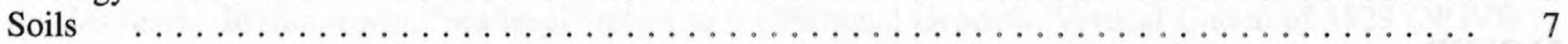

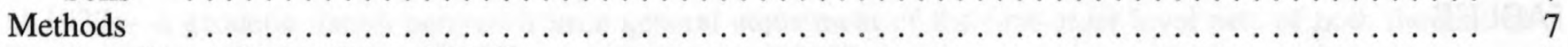

Selection and Locations of Wells $\ldots \ldots \ldots \ldots \ldots \ldots \ldots \ldots \ldots \ldots \ldots \ldots \ldots \ldots \ldots \ldots \ldots$

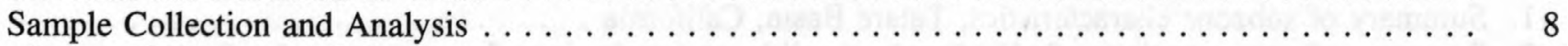

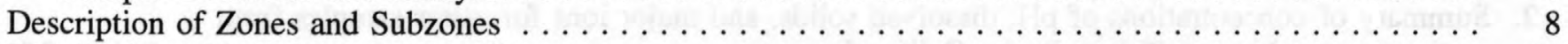

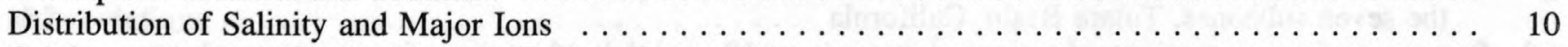

Origin and Isotope Composition of Shallow Ground Water $\ldots \ldots \ldots \ldots \ldots \ldots \ldots$

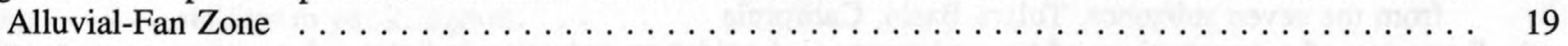

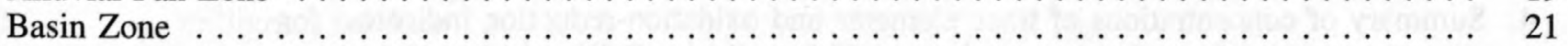

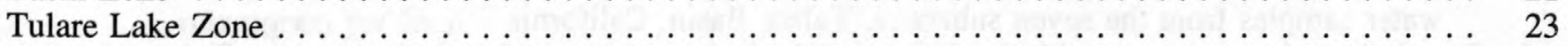

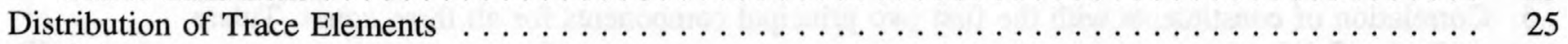

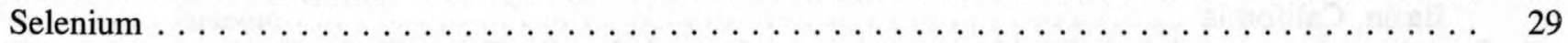

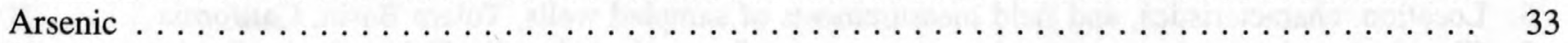

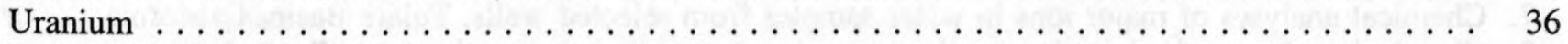

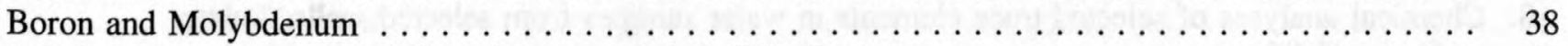

Interrelations among Dissolved Constituents and their Distributions $\ldots \ldots \ldots \ldots \ldots \ldots \ldots$

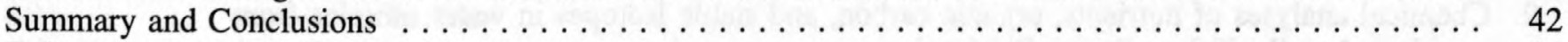

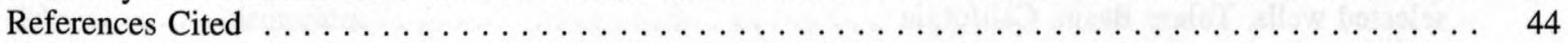

\section{PLATE}

[Plate is in pocket at back of report]

1. Geologic map of the Tulare Basin, California

\section{FIGURES}

1,2. Maps showing:

1. Location of study area and sampling sites $\ldots \ldots \ldots \ldots \ldots \ldots \ldots \ldots \ldots \ldots$

2. Distribution of salinity for all subzones in the Tulare Basin, California $\ldots \ldots \ldots \ldots 13$

3-5. Diagrams showing:

3. Major ion composition in water samples from the alluvial-fan zone: west-side alluvium (CR) and east-side alluvium $(\mathrm{SN})$ subzones, Tulare Basin, California $\ldots \ldots \ldots \ldots \ldots \ldots$

4. Major ion composition in water samples from the basin zone: west-side basin (BW) and

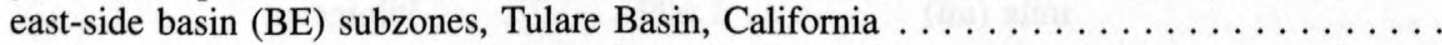

5. Major ion composition in water samples from the Tulare Lake zone: northeastern margin (NEM), southern/western margin (SWM), and Tulare Lake bed (TLB) subzones,

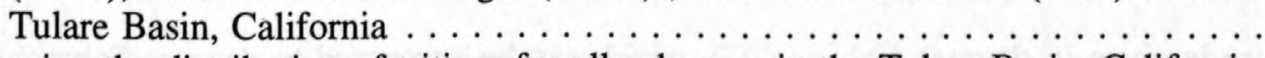

6. Map showing the distribution of tritium for all subzones in the Tulare Basin, California . . . . . . 22

7-9. Graphs showing:

7. Relation between delta oxygen-18 and delta deuterium for water samples from the alluvial-fan zone, Tulare Basin, California $\ldots \ldots \ldots \ldots \ldots \ldots \ldots \ldots \ldots \ldots \ldots \ldots \ldots \ldots \ldots$

8. Relation between delta oxygen-18 and delta deuterium for water samples from the

9. Relation zone, Tulare Basin, California $\ldots \ldots \ldots \ldots \ldots \ldots \ldots \ldots \ldots \ldots \ldots \ldots$ feen delta oxygen- 18 and delta deuterium for water samples from Tulare Lake zone, Tulare Basin, California 
10. Diagram showing critical redox potential at $\mathrm{pH} 5$ and 7.5 for redox couples pertinent to this

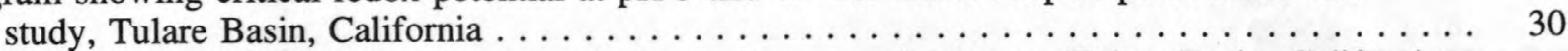

11-15. Maps showing distribution of trace elements for each zone and subzone, Tulare Basin, California:

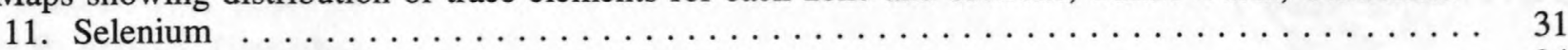

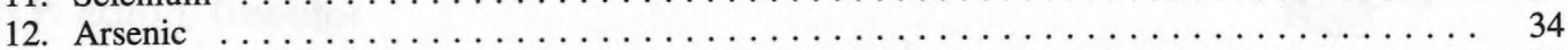

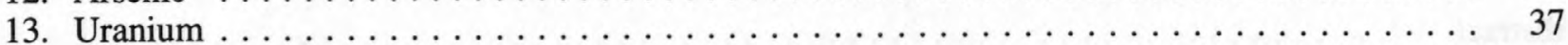

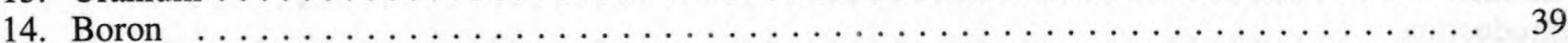

15. Molybdenum . . . . . . . . . . . . . . . . . . . . . . . 40

\section{TABLES}

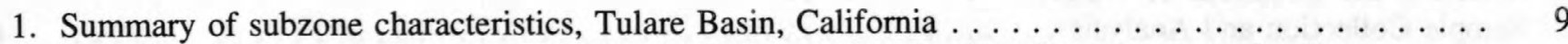

2. Summary of concentrations of $\mathrm{pH}$, dissolved solids, and major ions for water samples from

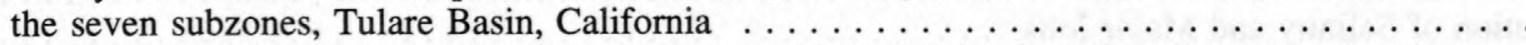

3. Summary of concentrations of tritium, delta oxygen-18, and delta deuterium for water samples from the seven subzones, Tulare Basin, California $\ldots \ldots \ldots \ldots \ldots \ldots \ldots \ldots \ldots \ldots \ldots \ldots$

4. Summary of concentrations of trace elements and oxidation-reduction indicators for water samples from the seven subzones, Tulare Basin, California $\ldots \ldots \ldots \ldots \ldots \ldots$

5. Correlation of constituents with the first two principal components for all three zones, Tulare

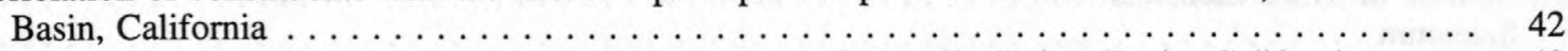

6. Location, characteristics, and field measurements of sampled wells, Tulare Basin, California . . . . 49

7. Chemical analyses of major ions in water samples from selected wells, Tulare Basin, California $\ldots 52$

8. Chemical analyses of selected trace elements in water samples from selected wells, Tulare

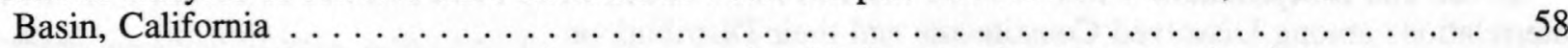

9. Chemical analyses of nutrients, organic carbon, and stable isotopes in water samples from selected wells, Tulare Basin, California

\section{CONVERSION FACTORS, WATER-QUALITY INFORMATION, VERTICAL DATUM, ABBREVIATIONS, ACRONYMS, AND WELL-NUMBERING SYSTEM}

\section{Conversion Factors}

\begin{tabular}{rcl}
\hline Multiply & By & To obtain \\
\hline acre & 0.4047 & hectare \\
acre & 4,047 & square meter \\
acre-foot (acre-ft) & 1,233 & cubic meter \\
acre-foot (acre-ft) & 0.001233 & cubic hectometer \\
foot (ft) & 0.3048 & meter \\
inch (in.) & 25.4 & millimeter \\
mile (mi) & 1.609 & kilometer \\
& & \\
\hline
\end{tabular}

Temperature is given in degrees Celsius $\left({ }^{\circ} \mathrm{C}\right)$, which can be converted to degrees Fahrenheit $\left({ }^{\circ} \mathrm{F}\right)$ by the following equation:

$$
{ }^{\circ} \mathrm{F}=1.8\left({ }^{\circ} \mathrm{C}\right)+32
$$




\section{Water-Quality Information}

Chemical concentrations are given iin milligrams per liter $(\mathrm{mg} / \mathrm{L})$ or micrograms per liter $(\mu \mathrm{g} / \mathrm{L})$. Milligrams and micrograms per liter are units expressing the weight of the solute per unit volume (liter) of water. One thousand micrograms per liter is equivalent to 1 milligram per liter. Milligrams per liter is approximately equivalent to parts per million. Micrograms per liter is approximately equivalent to parts per billion.

\section{Vertical Datum}

Sea level: In this report, "sea level" refers to the National Geodetic Vertical Datum of 1929 (NGVD of 1929) - a geodetic datum derived from a general adjustment of the first-order level nets of both the United States and Canada, formerly called Sea Level Datum of 1929.

$\begin{array}{ll}\text { Abbreviations } & \\ \mathrm{mg} / \mathrm{kg} & \begin{array}{l}\text { milligram per kilogram } \\ \mathrm{mg} / \mathrm{L}\end{array} \\ \mu \mathrm{g} / \mathrm{L} & \text { milligram per liter } \\ & \\ \mathrm{As} & \text { arsenic } \\ \mathrm{As}(\mathrm{III}) & \text { arsenite } \\ \mathrm{As}(\mathrm{V}) & \text { arsenate } \\ \mathrm{BE} & \text { east-side basin } \\ \mathrm{BW} & \text { west-side basin } \\ \mathrm{CR} & \text { west-side alluvium } \\ \mathrm{D} & \text { deuterium } \\ \mathrm{NEM} & \text { northeastern margin } \\ { }^{18} \mathrm{O} & \text { oxygen-18 } \\ \text { permil } & \text { parts per thousand } \\ \text { redox } & \text { oxidation/reduction } \\ \mathrm{Se} & \text { selenium } \\ \mathrm{Se}(0) & \text { elemental selenium } \\ \mathrm{Se}(\mathrm{IV}) & \text { selenite } \\ \mathrm{Se}(\mathrm{VI}) & \text { selenate } \\ \mathrm{SN} & \text { east-side alluvium } \\ \mathrm{SWM} & \text { southern/western margin } \\ \text { TLB } & \text { Tulare Lake bed } \\ \text { TU } & \text { tritium units } \\ \mathrm{U} & \text { uranium } \\ \mathrm{U}(\mathrm{IV}) & \text { uranous } \\ \mathrm{U}(\mathrm{VI}) & \text { uranyl } \\ & \end{array}$

\section{Acronyms}

USEPA U.S. Environmental Protection Agency

USGS U.S. Geological Survey 
Wells are identified and numbered according to their location in the rectangular system for the subdivision of public lands. The identification consists of the township number, north $(\mathrm{N})$ or south (S); the range number, east $(\mathrm{E})$ or west $(\mathrm{W})$; and the section number. Each section is further divided into sixteen 40-acre tracts lettered consecutively (except I and O), beginning with 'A' in the northeast corner of the section and progressing in a sinusoidal manner to ' $R$ ' in the southeast corner. Within the 40 -acre tract, wells are sequentially numbered in the order they are inventoried. The final letter refers to the base line and meridian. In California, there are three base lines and meridians; Humboldt $(\mathrm{H})$, Mount Diablo $(\mathrm{M})$, and San Bernardino (S). All wells in the study area are referenced to the Mount Diablo base line and Meridian (M), except two wells in the San Bernardino base line and meridian (S). Well numbers (State well no.) in tables 5 to 8 are abbreviated and are written, for example, 20S/20E-9N1M. Identification of sampling sites (fig. 2) are referred to only by their section designation; for example, $9 \mathrm{~N} 1$.

RANGE
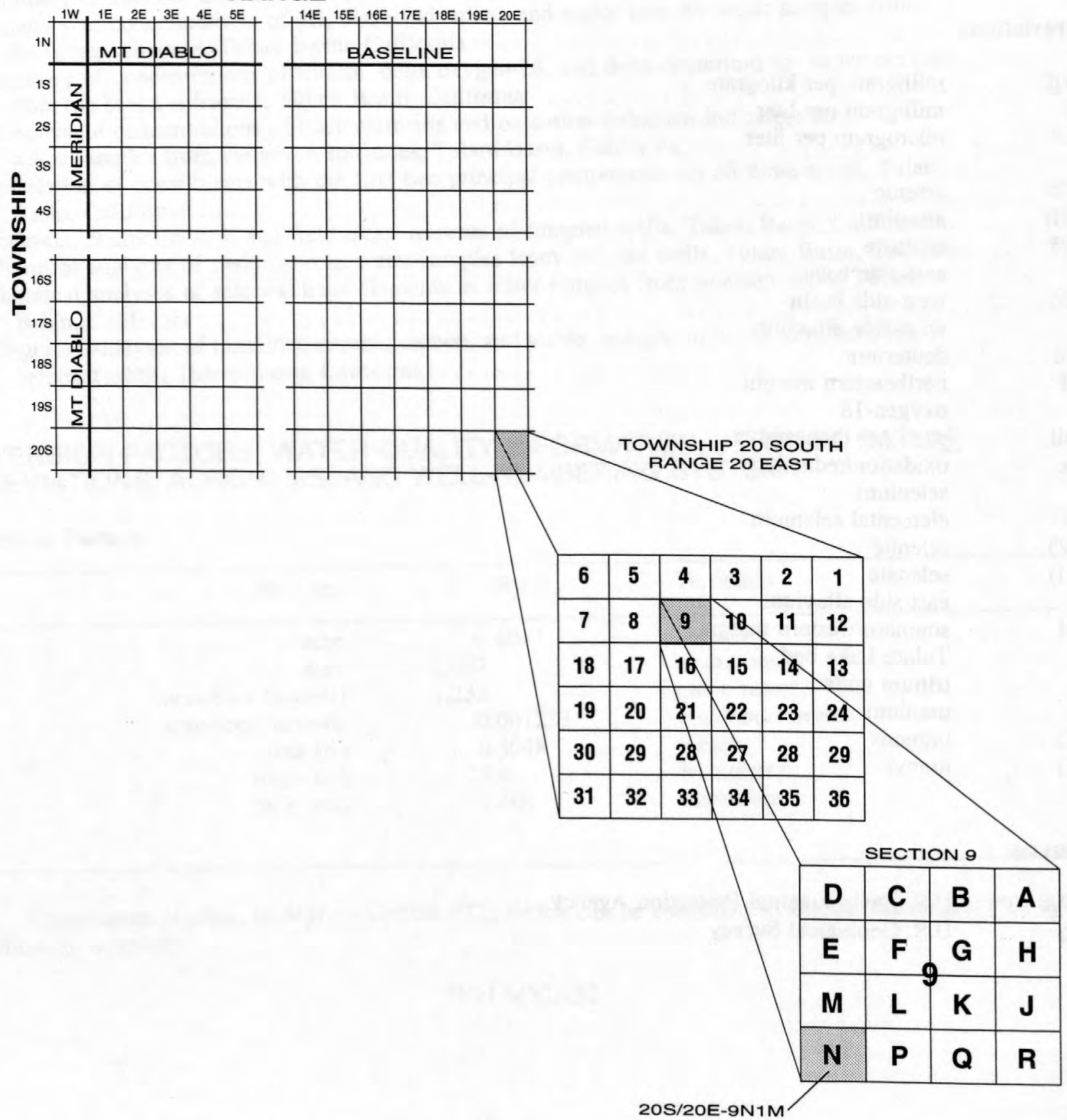


\title{
AREAL DISTRIBUTION OF SELECTED TRACE ELEMENTS, SALINITY, AND MAJOR IONS IN SHALLOW GROUND WATER, TULARE BASIN, SOUTHERN SAN JOAQUIN VALLEY,
}

CALIFORNIA

\author{
By Roger Fujii and Walter C. Swain
}

\begin{abstract}
The distribution of salinity and selected trace elements in shallow ground water in the Tulare Basin, California, was assessed to evaluate potential problems related to disposal in evaporation ponds of irrigation drain water containing elevated concentrations of selenium and other trace elements. The constituents of primary concern were selenium, arsenic, and salinity; uranium, boron, and molybdenum also were evaluated. Samples from 117 shallow wells were analyzed, and the results for samples from 110 of the wells were interpreted in relation to surficial geology, sediment depositional environment, soil characteristics, and hydrologic processes to determine the geochemical and hydrologic factors affecting the distribution of these constituents in ground water.
\end{abstract}

In general, shallow ground water in areas where concentrations of salinity and most trace elements are elevated is influenced primarily by sediments derived from marine sedimentary rocks originating in the Coast Range, San Emigdio Mountains, and Tehachapi Mountains, and probably by unusual exposures of similar marine formations in the Sierra Nevada. Ground water in areas where concentrations of salinity and trace elements are significantly lower generally is influenced by igneous and metamorphic rocks exposed in the Sierra Nevada.

In addition to sources of sediments, evaporation of shallow ground water, as indicated by isotopic enrichment of oxygen-18 and deuterium, increases salinity and concentrations of conservative trace elements such as selenium (under oxidizing conditions) and boron. Redox conditions affect the oxidation state of all trace elements of concern, except boron, and were found to be a major influence on trace-element solubility. Under oxidized conditions, selenate predominates and behaves conservatively, and arsenate predominates and is affected by sorption reactions that can limit arsenic solubility. Under reduced conditions, selenium is reduced to insoluble elemental selenium and arsenite predominates and generally is more soluble than arsenate.

Elevated concentrations of uranium in shallow ground water probably are associated with uranium deposits in Kern County and other parts of the basin where oxidized conditions cause the more soluble uranyl species to predominate. Boron was correlated with salinity and behaved conservatively, whereas adsorption and precipitation of molybdenum minerals probably limited molybdenum solubility.

Interrelations among constituents were examined with principal component analysis. The first two principal components explained 50.7 percent of the variance in the data. The first principal component was related to salinity, and the second principal component was related to redox conditions, reflecting two of the major influences on shallow groundwater quality found in this study. 


\section{INTRODUCTION}

Elevated concentrations of selenium (Se) in shallow ground water and in agricultural drain water in the western San Joaquin Valley, California (Deverel and others, 1984; Presser and Barnes, 1984), were identified as the principal cause of high mortality and deformity rates of waterbirds at Kesterson National Wildlife Refuge (Ohlendorf and others, 1986). Irrigated agricultural areas throughout the San Joaquin Valley affected by saline shallow ground water typically are drained using subsurface drainage systems to prevent accumulation of water and salts in the crop-root zone. Drain water that contains high concentrations of selenium and other trace elements and is disposed of in agricultural evaporation ponds exposes waterbirds to potentially toxic levels of trace elements. These problems have led to concern that selenium and other trace elements may be present in potentially toxic concentrations in shallow ground water in the affected areas of the Tulare Basin in the southern San Joaquin Valley (fig.1).

Previous studies of shallow ground-water quality in the Tulare Basin involved sampling of agricultural drain sumps (California Department of Water Resources, 1985, 1986) and drain-water evaporation pond inlets and ponds (California Regional Water Quality Control Board, Central Valley Region, 1988). Fujii (1988) reported the quality of drain water entering evaporation ponds and the pond water, and Schroeder and others (1988) evaluated related effects of drain water on water quality and waterbirds near Tulare Lake bed. These reports identified drain water and evaporation ponds with dissolved selenium concentrations as high as 919 $\mu \mathrm{g} / \mathrm{L}$, confirming that selenium is present at concentrations associated with high rates of mortality and deformity of waterbirds. Skorupa and Ohlendorf (1989) reported levels of drain-water contaminants, including selenium, in eggs collected at evaporation-pond habitats. These contaminants were related to deformities in waterbirds that inhabit the evaporation ponds in the Tulare Basin. All of these studies, however, covered only a small part of the Tulare Basin where ground water is within $20 \mathrm{ft}$ of land surface (California Department of Water Resources, 1987).

The overall objective of the study described here is to evaluate the distribution of salinity and trace elements in shallow ground water in areas where the water table is within $20 \mathrm{ft}$ of the land surface in the Tulare Basin, which includes parts of Kings, Tulare, and Kern Counties (fig. 1). This study was done by the U.S. Geological Survey in cooperation with the California Department of Water Resources and the San Joaquin Valley Drainage Program.

This report focuses on the distribution of selenium (Se) and arsenic (As) and secondarily on the distribution of uranium (U), boron (B), and molybdenum (Mo). This evaluation, combined with existing data, allows a preliminary assessment of shallow ground-water quality and provides a guide for future studies. This report describes the distribution of salinity, major ions, and selected trace elements in shallow ground water and assesses shallow ground-water quality in relation to surficial geology, sediment depositional environment, soil characteristics, and hydrologic processes.

\section{DESCRIPTION OF STUDY AREA}

The study area is defined as the areas where the water table is within $20 \mathrm{ft}$ of land surface in the hydrologically closed Tulare Basin in the southern one-third of the San Joaquin Valley (fig. 1). Areas where ground water is within $20 \mathrm{ft}$ of the land surface, 886,000 acres, were mapped in 1987 (California Department of Water Resources, 1987). These areas were reduced by about 88,000 acres because the water table in the sparsely irrigated parts of Kern County and in adjacent Tulare County was found to be more than $20 \mathrm{ft}$ below land surface at the time of sampling. In addition, access to private lands in Kings County immediately north of Kern County and on the Buena Vista Lake bed in Kern County could not be obtained, further reducing the study area by about 102,000 acres to an effective total of about 696,000 acres.

The climate in the Tulare Basin is characterized by hot, dry summers with maximum temperatures in excess of $43{ }^{\circ} \mathrm{C}$, and cool, moist, foggy winters with temperatures seldom below $\mathrm{O}^{\circ} \mathrm{C}$. Total precipitation averages 4 to $8 \mathrm{in}$./yr, most falling between October and April (Preston, 1981).

Vegetation in the study area prior to agricultural development reflected the availability of runoff, primarily from the Sierra Nevada. The basin trough, which includes most of the study area, 
was dominated characteristically by tule marshes, except in areas of perennial lakes. The adjacent uplands were typically saltbush with the exception of the upper South Fork Kings River alluvial fan, which was oak savannah (Preston, 1981).

Present day land use is dominated by irrigated agriculture; cotton is the principal crop. The earliest irrigation in the study area probably was on the Kings River alluvial fan prior to 1890 . By 1894 , the middle and upper parts of the fan were dominated by diversified farms, and the lower part of the fan was devoted to grains and grazing (Preston, 1981). Irrigated agriculture continued to expand throughout the study area using ground water on the eastern margins that was available initially as artesian flows and later pumped. Diversion of streams from the Sierra Nevada contributed to the shrinkage and ultimate extinction of Tulare Lake, except in extremely wet years. Flood-control dams on the principal streams (the Kings, Kaweah, Tule, and Kern Rivers) have effectively controlled most floodflows in the basin and have allowed for the conversion of virtually the entire lake bed to irrigated agriculture, destroying almost all wetland habitat. The stored stream water is used for irrigation through the summer months. Construction of the California Aqueduct and deliveries of Sacramento River and Sacramento-San Joaquin River Delta waters to the west side of the Tulare Basin in the early 1970's provided the basis for the last major increases in irrigated lands, most of which are in western and southern Kern County.

\section{Geology}

The Tulare Basin is a subsidence basin characterized by a broad structural trough on its west and south sides. This internally drained basin is surrounded by highly contrasting geologic source materials (California Division of Mines and Geology, 1969). The eastern side of the basin is defined by the Sierra Nevada, only the margin of which is shown in plate 1. The Sierra Nevada is composed predominantly of Pre-Tertiary granitic rocks with common occurrences of metamorphic and extrusive volcanic rocks. Marine sedimentary rocks of Miocene age crop out at the valley floor margin, starting near the Kern and Tulare Counties boundary and extending south of Bakersfield. The western boundary of the Tulare Basin is formed by the predominantly marine sedimentary Temblor and Diablo Ranges of the Coast Range. The southeastern boundary is defined by the Tehachapi Mountains, transitional from the Sierra Nevada to the north and east and the San Emigdio Mountains to the west. Nonmarine sediments of Pliocene and Pleistocene age also are common in the western part of the Tulare Basin (California Division of Mines and Geology, 1969). The San Emigdio Mountains form the southwestern boundary, adjacent to the Temblor Range to the north and the Tehachapi Mountains to the east. Much of the San Emigdio Mountains are composed of marine sedimentary rocks of Jurassic to Pliocene age that are highly faulted and deformed. The northern boundary of the basin is formed by coalescing alluvial fans formed by Los Gatos Creek from the Coast Range and the Kings River from the Sierra Nevada (California Division of Mines and Geology, 1969).

Materials underlying the valley floor consist of nonmarine and marine sediments ranging in age from Holocene to Cretaceous. These sediments overlie basement rocks of the Sierra Nevada and the Coast Range at depths of 0 to $35,000 \mathrm{ft}$ (Page, 1986). Depths to bedrock are greatest in the vicinity of Buena Vista Lake bed (Norris and Webb, 1990).

Structural deformation associated with the Sierra Fault Block tilting to the west and the periodic uplift of the Coast Range through the Pleistocene age has produced a series of anticlinal exposures of the Tulare Formation of Pliocene and Pleistocene age in northwestern Kern County. These structural features, the Semitropic and Buttonwillow Ridges and the Lost Hills Anticline (pl. 1), trend northwest to southeast parallel to the Coast Range and the basin trough. Channels parallel to the ridges historically carried floodflow from the Kern River northward to the Tulare Lake bed but currently convey irrigation water and irrigation return flow. The ridges appear to impede the movement of ground water and are partially affected by shallow ground water.

The Kern and Tulare ground-water basins lie generally east and north of the basin trough in areas dominated by relatively coarse alluvium from the Sierra Nevada (Davis and others, 1959). The Kern 


\section{EXPLANATION}

\section{SUBZONES}

\section{TIDI BOUNDARY OF VALLEY DEPOSITS}

STUDY AREA BOUNDARY $-<20$ feet to ground water

WELL AND ABBREVIATED NUMBER - Number ending in "S" indicates well is referenced to the San Bernardino base line and meridian. All other wells are referenced to the Mount Diablo base line and meridian. See "Well-Numbering System" for complete description of well identification $\triangle$ West-side alluvium

- East-side alluvium

口 West-side basin

- East-side basin

- Northeastern margin

- Southern/Western margin

- Tulare Lake bed

- Miscellaneous sites

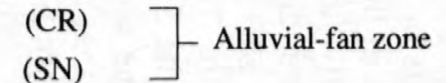

(BW) - Basin zone

(BE)

(NEM)

(SWM) - Tulare Lake zone

(TLB)

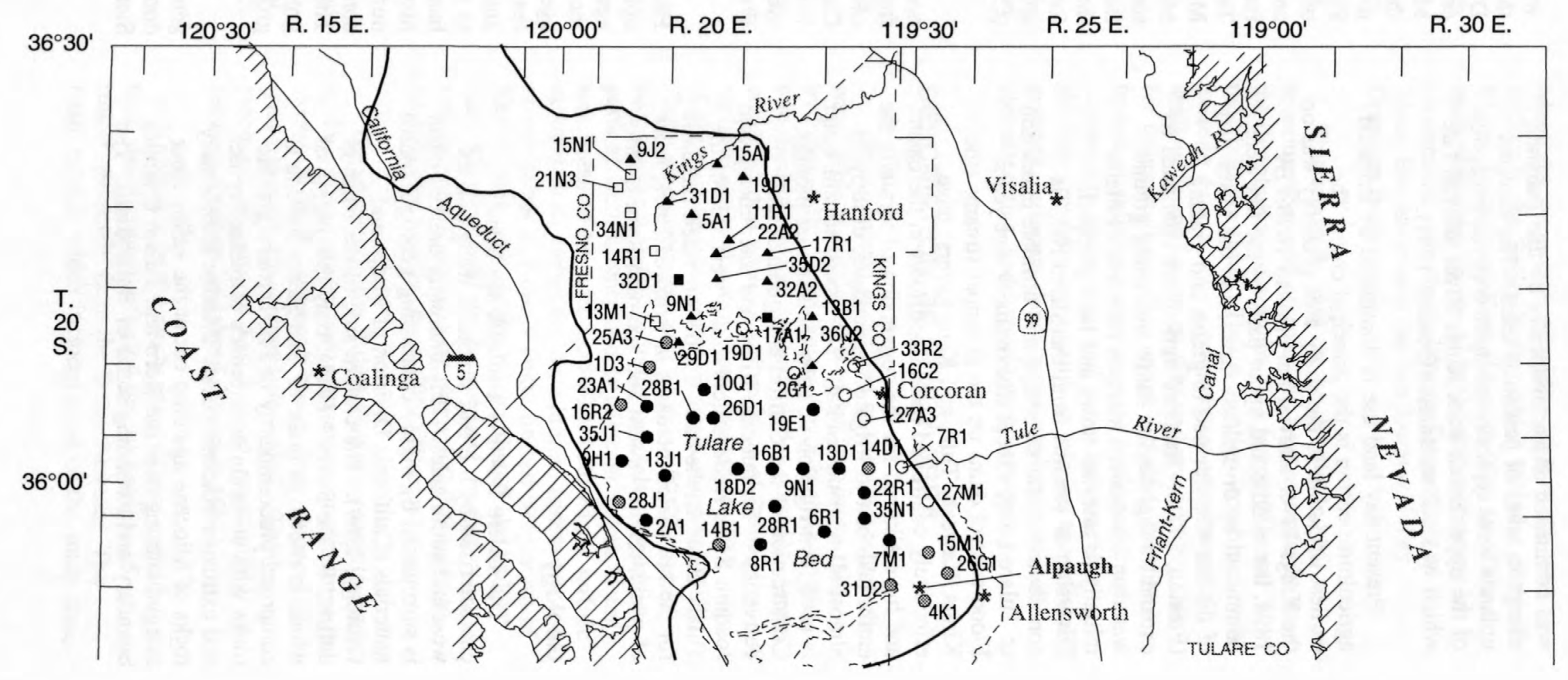




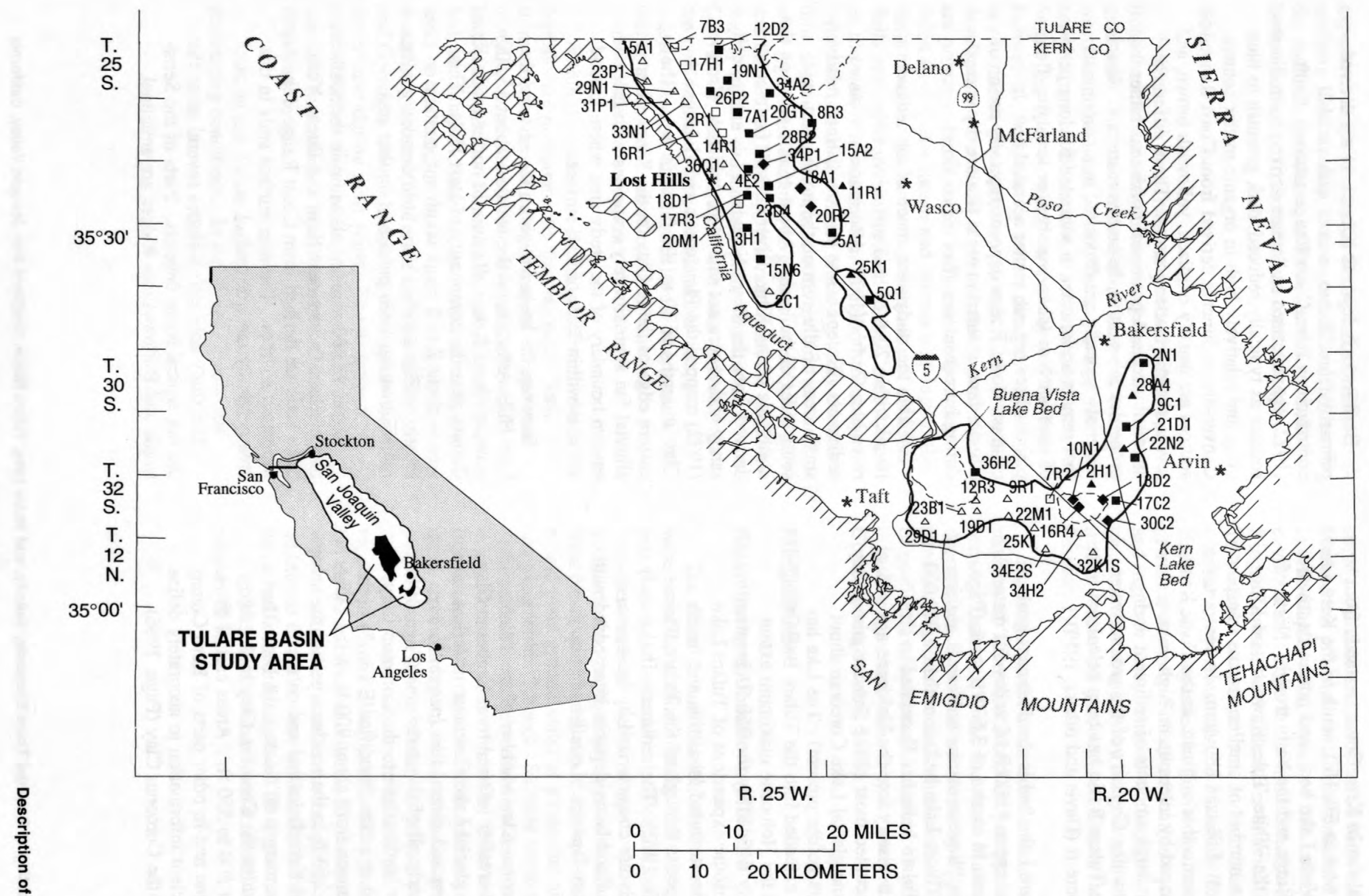

Figure 1. Location of study area and sampling sites. 
River alluvial fan in Kern County extends from Bakersfield west to Elk Hill, south to the Kern Lake and Buena Vista Lake beds, and northwest toward Semitropic Ridge and the basin trough. North of Bakersfield, the White, Tule, Kaweah, and Kings Rivers and a number of smaller streams transport large volumes of Sierran alluvium. In contrast, the west-side streams that originate in the Coast Range are characterized by intermittent, high-volume flows that transport large amounts of sediment during infrequent storms. Capacity of the ground-water basins in the Tulare Basin has been calculated to be 93 million acre-ft (Davis and others, 1959).

The Tulare Lake bed is the dominant geologic feature in the upper $4,000 \mathrm{ft}$ of valley-fill materials. Lake sediments in excess of 3,600 ft thick (Page, 1986) rest on Pliocene marine sediments, making the historic Tulare Lake bed more than 2,000,000 years old. Tulare Lake has fluctuated in size throughout its history into the Holocene age and, at one time, occupied most of the San Joaquin Valley (as Pleistocene glacial Lake Corcoran about 600,000 years before present). The lake has periodically extended into the Tulare Basin trough well beyond the Holocene maximum extent approximately defined by the $220-\mathrm{ft}$ elevation contour. Periodic expansions of Tulare Lake resulted in fine-textured lacustrine and marsh (paludal) deposits throughout the Tulare Basin trough (Croft, 1972). The sediments in the study area generally are characterized by lacustrine, paludal, and flood-basin deposits interbedded with coarser stream deposits. Locally, sand may dominate.

The Corcoran Clay Member of the Tulare Formation (hereafter referred to as Corcoran Clay), deposited in glacial Lake Corcoran, underlies most of the western and central San Joaquin Valley, including nearly all of the study area (Page, 1986). Depth below land surface to the Corcoran Clay (also referred to as the "modified E Clay") in the study area ranges from about $900 \mathrm{ft}$ on the Tulare Lake bed to $250 \mathrm{ft}$ in the southern part of the study area south of Kern Lake bed and on the southwestern margin of Tulare Lake bed. The average depth to the Corcoran Clay in the study area is about 500 to $550 \mathrm{ft}$. Areas east of the Lost Hills Anticline and in other parts of Kern County have insufficient information to accurately define the depth to the Corcoran Clay (Page, 1986).
Basin-trough deposits (Qb, pl. 1) are derived primarily from Sierran sources with variable contributions from Coast Range sources. Croft (1972) characterized sediments derived from Sierran sources as typically reduced, dark greenish to blue gray, and relatively high in organic matter content. Conversely, sediments derived from Coast Range sources are usually oxidized, yellowish brown, and low in organic matter content. These differences are attributed to depositional conditions rather than properties inherent to the source materials. Sierran materials typically are deposited in environments that remain underwater or saturated for long periods of time, such as lakes, marshes, or low-lying flood plains where organic matter accumulates. In contrast, Coast Range deposits typically are on alluvial fans or interfan areas that are dry except during infrequent runoff or debris flows.

Within the study area, much of the sediment found within $20 \mathrm{ft}$ of land surface visually resembles Croft's (1972) description of reduced sediments. Exceptions to this are distinct, relatively small areas of alluvium on the north, west, and south sides of the basin. About 46,000 acres on the north side of the Kings River alluvial fan are derived from the Sierra Nevada. Soils are typically sandy and, where not saturated, oxidized. Croft (1972) mapped the Pleistocene and Holocene A Clay at depths of 60 to $100 \mathrm{ft}$ in this area. The eastern edge of the A Clay on the Kings River alluvial fan approximately coincides with the eastern boundary of the study area where ground water is within $20 \mathrm{ft}$ of land surface.

Between the basin trough on the east and the Lost Hills Anticline on the west are about 15,000 acres of Coast Range alluvium in northwestern Kern County near the community of Lost Hills. This area is about 2 to $3 \mathrm{mi}$ in width and contains mostly oxidized soils. Very little detailed geologic information has been published on this area.

About 16,000 acres of alluvium in the southern part of Kern County near Kern and Buena Vista Lake beds are derived from Coast Range-Tehachapi Mountain sources. The near-surface soils in this area generally are oxidized.

The study area also includes several areas that are not typical basin deposits. Parts of the Semitropic and Buttonwillow Ridges are anticlinal 
exposures in the vicinity of Goose Lake bed in northern Kern County. Relict sand dune deposits on the southern boundaries of Tulare and Kern Lake beds constitute $<5$ percent of the total area (pl. 1).

\section{Soils}

Soils in the study area are primarily developed from materials recently transported from the mountains that enclose the Tulare Basin on the west, south, and east sides. The exceptions are soils formed on the anticlinal Buttonwillow and Semitropic Ridges, which are outcrops of the Tulare Formation. Soils closely reflect the depositional environments discussed above, with minimal profile development. Aridisols, the most developed soils, are primarily found on the basin rim at the transition from Coast Range and Sierran alluvium to the basin trough, reflecting relative stability of aridisols. Soils developed in the alluvium of the Coast Range on the west side and the San Emigdio Mountains on the south side of the Tulare Basin typically contain little organic matter. These soils are fine textured with significant amounts of gypsum $\left(\mathrm{CaSO}_{4} \cdot 2 \mathrm{H}_{2} \mathrm{O}\right)$ and thenardite $\left(\mathrm{Na}_{2} \mathrm{SO}_{4}\right)$, inherited from the predominantly marine sedimentary parent materials. Conversely, soils formed in alluvium derived from the predominantly igneous Sierra Nevada are coarser textured, have higher levels of organic matter and lower concentrations of salts, and contain little or no gypsum.

Within the basin trough, soils formed in basin deposits are predominantly fine textured. Sand from channel deposits also is present. The basin trough is dominated by four dry lakebeds, the largest of which is Tulare Lake bed. Tulare Lake bed, including the lakebed area and the wetland areas on the margins on the lake, is mapped as lacustrine deposits (California Division of Mines and Geology, 1969). Historically the lakebed was underwater during most years. The wetland areas received inflows and also were submerged on a seasonal basis, with a high degree of variability from year to year.

Soils on the Tulare Lake bed reflect these contrasting conditions. In the Kings County soil survey (Arrouse and Anderson, 1986), soils on the lakebed are predominantly fine-textured Mollisols (Vertic Haplaquolls) deposited in a subaqueous environment. Soils in the transitional zone from the Kings, Kaweah, and Tule River alluvial fans to Tulare Lake on the northern and northeastern margins are coarser-textured Mollisols (Fluvaquentic Haploxerolls) deposited in fluvial environments by perennial streams. Soil classification is complex and involves many criteria, but Mollisols are characterized primarily by mineral soil with organic matter content $>3$ percent (Soil Conservation Service, 1975).

In contrast, soils in the southern and western margins of Tulare Lake bed are predominantly finetextured Entisols (Vertic and Aeric Fluvaquents) deposited in fluvial environments by ephemeral streams. Entisols are soils characterized by a lack of profile development and contain $<3$ percent organic matter and commonly $<1$ percent (Soil Conservation Service, 1975).

\section{METHODS}

\section{Selection and Locations of Wells}

The selection and location of observation wells were based on several criteria. An existing well was considered suitable if its location was consistent with the well coverage and density design desired in the study area, was constructed with plastic pipe and a cap at the bottom, and would yield ground water at a rate that allowed sampling within 3 hours. Suitable locations for additional observation wells were restricted because extensive areas were affected by flood irrigation, the presence of irrigation canals and reservoirs, drain-water ditches and drain-water evaporation ponds, and by inaccessibility to private property. As a result, most wells were located on, or adjacent to, a right-of-way along public and private roads. On the basis of these criteria, 55 existing wells were identified as suitable for sampling, and an additional 62 wells were drilled for the study. The wells had a median depth of $19 \mathrm{ft}$ and ranged from 12.1 to $24.9 \mathrm{ft}$, and most were screened over the bottom $10 \mathrm{ft}$. 


\section{Sample Collection and Analysis}

Water samples were collected from 117 shallow observation wells in the Tulare Basin (fig. 1) from May to August 1989. The samples were collected using a peristaltic pump after a minimum of three well-casing volumes were withdrawn and the general chemical character of the water had stabilized, as indicated by relatively constant specific conductance and $\mathrm{pH}$. Standard field methods (U.S. Geological Survey, 1980) were used to collect samples for laboratory analyses.

Chemical analyses were done by or through the U.S. Geological Survey (USGS) National Water Quality Laboratory in Arvada, Colorado, using USGS methods (Fishman and Friedman, 1989). Hydrogen $(\mathrm{H})$, oxygen $\left(\mathrm{O}_{2}\right)$, and tritium isotopic composition were determined by the USGS Isotopic Fractionation Laboratory in Reston, Va.

In addition to the internal quality assurance practices of the USGS laboratories (Jones, 1987), 10 duplicate samples were collected and analyzed (see tables 6 through 9 at back of report). Differences between duplicate analyses generally were $<20$ percent relative difference. In addition, several wells containing water with high concentrations of selenium were resampled in January 1990, and initial results for selenium were confirmed.

\section{DESCRIPTION OF ZONES AND SUBZONES}

Shallow ground-water quality in the study area is extremely variable with concentrations of most dissolved constituents ranging 2 to 3 orders of magnitude. Figure 1 shows the location of each sampling site and its subzone designation.

Concentrations of constituents in water samples from all 117 wells are presented in tables 6 through 9 (at back of report).

The surficial geology of the study area is complex, dominated by alluvial-fan, flood-basin, and lacustrine deposits. Sediments are derived from the Coast Range, San Emigdio and Tehachapi Mountains, and the Sierra Nevada. To further assess the distribution of dissolved constituents in shallow ground water, each of the three dominant surficial geologic map units (alluvial-fan, floodbasin, and lacustrine deposits) (pl. 1) is considered in the context of its depositional environment and its relation to sediment sources. This breakdown results in three zones (alluvial-fan zone, basin zone, and Tulare Lake zone) and seven distinct subzones (pl. 1) that provide a framework for interpreting shallow ground-water quality. A summary of subzone characteristics is provided in table 1 .

The alluvial-fan zone is divided into west-side alluvium (CR) subzone, derived from the Coast Range and San Emigdio Mountains, and east-side alluvium (SN) subzone, derived from the Sierra Nevada and Tehachapi Mountains. Outcrops of the deformed Tulare Formation at Semitripic Ridge and Buttonwillow Ridge were excluded from the data analysis because of their greater age. Sample sites on Semitropic Ridge are grouped under miscellaneous sites in tables $6,7,8$, and 9 . The change from the CR subzone to the SN subzone is defined south of Kern Lake bed in plate 1. The natural transition is not abrupt and is approximated by the I-5 Highway corridor. Natural drainage features in that area have been highly modified by land-use practices. Three wells in northwestern Kern County, 34P1, 18A1, and 20R2 (fig. 1), are not included in the alluvial-fan subzone because Semitropic Ridge is an anticlinal outcrop of the older Tulare Formation rather than more recent alluvium.

The basin zone consists of mixed sources of flood-basin deposits dominated by Sierran sediments (Davis and others, 1959; Croft, 1972; Page, 1986) with an increasing proportion of Coast Range sediments contributing to the west side of the zone. East-side (BE) subzone and west-side (BW) subzone flood-basin deposits generally are defined in relation to present-day river, creek, and slough-channel locations.

Lacustrine deposits generally are dominated by Sierran sediments, but contain considerable interbedding of coarse- and fine-grained sediments of mixed origins. Most of the shallow ground-water samples from lacustrine depositional environments 
Table 1. Summary of subzone characteristics, Tulare Basin, California

\begin{tabular}{|c|c|c|c|}
\hline Subzone & $\begin{array}{l}\text { Depositional } \\
\text { envionment }\end{array}$ & Sediment sources & $\begin{array}{c}\text { Soil types } \\
\text { (Tulare Lake zone only) }\end{array}$ \\
\hline \multicolumn{4}{|l|}{ Alluvial-fan zone } \\
\hline West-side alluvium (CR) & alluvial fan & Coast Range and San Emigdio Mountains & \\
\hline East-side alluvium (SN) & alluvial fan & Sierra Nevada and Tehachapi Mountains & \\
\hline \multicolumn{4}{|l|}{ Basin zone } \\
\hline West-side basin (BW) & flood basin & Sierra Nevada with significant Coast Range influence & \\
\hline East-side basin (BE) & flood basin & Sierra Nevada & \\
\hline \multicolumn{4}{|l|}{ Tulare-Lake zone } \\
\hline Northeastern margin (NEM) & lake margin/wetland & Sierra Nevada & $\begin{array}{l}\text { Coarse-textured Mollisols } \\
\text { (Fluvaquentic Haploxerolls, } \\
\text { and Haplaquolls) }\end{array}$ \\
\hline Southern/Western margin (SWM) & $\begin{array}{l}\text { lake margin/ } \\
\text { ephemeral wetland }\end{array}$ & Coast Range with infrequent Sierra Nevada influence & $\begin{array}{l}\text { Entisols (Vertic and Aeric } \\
\text { Fluvaquents) and minor Aridisols } \\
\text { formed in sediment from } \\
\text { predominantly marine sources }\end{array}$ \\
\hline Tulare Lake bed (TLB) & lacustrine & Sierra Nevada and Coast Range & $\begin{array}{l}\text { Fine-textured Mollisols } \\
\text { (Vertic Haplaquolls) }\end{array}$ \\
\hline
\end{tabular}


were taken from the Tulare Lake zone, which is on the Tulare Lake bed. The Kern and Buena Vista Lake beds also are present at the southern end of the Tulare Basin, but only three sites were sampled on the Kern Lake bed, and no samples were collected from Buena Vista Lake bed because of lack of access permission.

Three principal contrasting depositional subzone environments within the Tulare Lake zone, mapped as lacustrine surficial deposits (California Division of Mines and Geology, 1969), have been delineated based on soil types (Arrouse and Anderson, 1986). The largest lacustrine deposit is the Tulare Lake bed that was under water most years prior to the dryingup of the lake. This deposit extends from the low point on the lakebed (about $178 \mathrm{ft}$ elevation) to an uneven boundary between 190 and $200 \mathrm{ft}$. This area is designated the Tulare Lake bed (TLB) subzone and is delineated by soils classified as finetextured Mollisols (Vertic Haplaquolls) in Kings County and by extrapolation, site evaluation, and communication with personnel from the Soil Conservation Service, U.S. Department of Agriculture (Kerry Arrouse, oral commun., 1992), in Tulare County (pl. 1).

The margins of Tulare Lake have two distinct depositional environments. The margins on the north and east sides of the lakebed received flows from the Kings, Kaweah, and Tule Rivers originating in the Sierra Nevada. Discharge from these streams probably provided enough water to support substantial marsh vegetation, even in dry years. This area is designated the northeasternmargin (NEM) subzone and is delineated by soils classified as relatively coarse-textured Mollisols formed in sediment deposited by the rivers (Fluvaquentic Haploxerolls and Haplaquolls) (Arrouse and Anderson, 1986).

The southern and western margins of the lakebed received streamflows on a much less regular and reliable basis from ephemeral streams in the Coast Range and from small ephemeral streams in the foothills of the Sierra Nevada, primarily Poso Creek (fig. 1). Floodflows from the Kern River reached Tulare Lake only in extremely wet years, and flow into the lake was restricted by sand ridges on the southern margins of the lake bed. This area is designated the southern/western-margin (SWM) subzone and contains soils classified primarily as poorly developed Entisols (Vertic and Aeric Fluvaquents), although some Aridisols also are present (Arrouse and Anderson, 1986).
Mollisols are characterized primarily as mineral soils with organic matter content $>3$ percent. Entisols are characterized by a lack of profile development and soil organic matter content $<3$ percent. Aridisols, minimally represented in the SWM subzone, exhibit profile development, including soil structure, clay translocation, and in situ accumulations of gypsum and calcium carbonate, consistent with older surfaces subject to infrequent surficial deposition of sediment (Soil Conservation Service, 1975).

Coincident with the flow regimes and depositional environments differentiating the NEM and SWM subzones is the difference in geologic sources of sediments and salts to these subzones. The sources of sediments to the NEM are primarily of igneous and metamorphic origin. In contrast, the SWM subzone is primarily affected by marine sediments from the Coast Range and by a combination of igneous and marine sediments from lower altitude foothills in the Sierra Nevada.

\section{DISTRIBUTION OF SALINITY AND MAJOR IONS}

The distribution of salinity and major ions in shallow ground water in the Tulare Basin is affected by many factors, including sources and quality of stream-water recharging and contributing salts to the shallow ground water; sources of sediments and soil-parent material; agricultural practices, such as irrigation and drainage; origin of irrigation water; hydrologic processes, such as evaporation and evapotranspiration; geochemical processes, such as ion exchange, mineral dissolution and precipitation; and biological reactions that especially affect oxidation/reduction (redox) sensitive elements, such as selenium. Salts and sediments transported by streams originating in the surrounding mountains have a major influence on shallow ground-water quality. The quality of the stream water and composition of sediments is largely dependent on the lithologic character of the rocks that are exposed in the respective stream-drainage areas.

The streams and rivers originating in the Sierra Nevada on the east side of the basin historically have provided most of the natural recharge to the basin prior to the damming of the large tributaries and the importation of irrigation water from the north. The general quality of the Kings and Kern Rivers, the largest rivers in the basin, is characterized by relatively low salinity, calcium 
bicarbonate and sodium bicarbonate type waters. For example, Davis and Coplen (1989) reported that a Kings River surface-water sample collected in 1984 had a dissolved-solids concentration of $25 \mathrm{mg} / \mathrm{L}$ and was composed of 50 percent calcium, 35 percent sodium, and 84 percent bicarbonate on an equivalent basis. Mendenhall and others (1916) report a mean composition for Kern River water sampled over a 1-year period around 1907 as having a dissolved-solids concentration of $127 \mathrm{mg} / \mathrm{L}$ composed of 43 percent sodium, 41 percent calcium, and 62 percent bicarbonate. These compositions reflect the influence of predominantly granitic rocks and smaller amounts of metamorphic and extrusive volcanic rocks exposed in the Sierra Nevada (Davis and others, 1959; Wood and Davis, 1959) that interact with precipitation recharging the streams. Smaller streams originating in the Sierra Nevada generally have similar water qualities. An exception to this is infrequent flushing of calcium sulfate type water from Poso Creek following drought periods such as the one that ended in 1978 (James Cooper, California Department of Water Resources, written commun., 1990). This anomaly probably reflects the effect of the Miocene marinesedimentary formations exposed in the Poso Creek drainage (California Division of Mines and Geology, 1969).

In contrast, the ephemeral streams originating in the Coast Range contribute considerably less water to the basin and have a mixed cation composition with sulfate and bicarbonate as predominant anions. Under low-flow conditions, the west-side streams are mainly calcium/sodium sulfate type waters. Davis (1961) reported that Bitterwater Creek had calcium sulfate type water with a dissolved-solids concentration of $3,200 \mathrm{mg} / \mathrm{L}$, Media Agua Creek had a calcium/sodium sulfate type water with a dissolved-solids concentration of $1,600 \mathrm{mg} / \mathrm{L}$, and Carneros Creek had a sodium/calcium sulfate type water with a dissolved-solids concentration of 1,900 $\mathrm{mg} / \mathrm{L}$. Davis (1961) contends that, under low-flow conditions, ground water contributes a greater proportion of the streamflow and better reflects the influence of lithology on water quality. Thus, higher salinity, calcium/sodium sulfate type waters generally reflect greater contribution from weathering of the Cretaceous and Tertiary marine sediments. Sources of calcium probably are related to gypsiferous sediments (also a source of sulfate) in continental deposits and calcium carbonate, which acts as a cementing agent in marine deposits. Another source of sodium and the major source of chloride is most likely connate water trapped in marine sediments (Davis, 1961) and dissolution of sodium chloride salts in marine sediments. Davis (1961) also hypothesizes that sulfate originates primarily from the oxidation of organic marine shales containing reduced iron sulfide minerals. Similarly, oxidation of iron sulfide minerals also has been reported for west-side streams in the central part of the western San Joaquin Valley (Presser and others, 1990; Presser and Swain, 1990).

Infrequent discharges from the basin have resulted in the accumulation of salts, which contributes to the saline, shallow ground water and soils in the study area. The difference between the low point of the Tulare Lake bed (about $178 \mathrm{ft}$ ) and the basin outlet at the northern boundary formed by the coalescing fans of Los Gatos Creek and Kings River is about $40 \mathrm{ft}$ (Mendenhall and others, 1916; Davis and Coplen, 1989). Discharges from the arid basin occurred only in extremely wet years; Tulare Lake has not discharged since 1878 (Davis and Coplen, 1989). Damming and diversion of east-side streams for irrigation purposes over the last century caused the extinction of Tulare Lake and account for the current hydrologically closed nature of the basin.

The evaporation and drying of the lakes (Tulare, Buena Vista, and Kern) in the basin have contributed salts to these areas. For example, Mendenhall and others (1916) reported changes in the water quality of Tulare Lake at different lake levels. Estimates of dissolved solids were calculated by summing the masses of reported inorganic soluble constituents. When the lake level was declining in 1880 , dissolved-solids concentrations ranged from 1,126 to $1,220 \mathrm{mg} / \mathrm{L}$ for samples collected at various points and depths in the lake. A dissolved-solids concentration of $4,792 \mathrm{mg} / \mathrm{L}$ was reported in 1889 when the lake level declined. Although many factors can affect lake salinity, evaporation of lake water probably contributed significantly to the increase in salinity. Mendenhall and others (1916) observed that the saline conditions found on the lakebed reflect either successive events of salt deposition resulting from evaporation of lake water followed by partial redissolution of salts or from precipitated salts left in place and mixed with subsequently deposited silts. These events probably occurred for many centuries as shown by the history of the lake and the highly mineralized conditions of the top few hundred feet of deposition (Mendenhall and others, 1916). 
Where the shallow ground water is or has been close enough to land surface to allow evaporation and evapotranspiration of shallow ground water, salts have accumulated at the soil surface and throughout the soil profile. Similar conditions have been reported for the central part of the western San Joaquin Valley (Deverel and Fujii, 1988; Fujii and others, 1988).

The highly saline soil conditions resulting from the evaporative concentration of lake water or shallow ground water required application of large quantities of irrigation water to reclaim the soil before agricultural development. Under these conditions, dissolution of evaporite salts by irrigation water and by weathering and ionexchange reactions occurring during the transport of water through the soil and sediments are significant processes that affect shallow ground-water quality in these areas.

Natural recharge of the shallow ground water under present-day conditions is minor relative to recharge from irrigation water in the study area, and both of these water sources contribute relatively small amounts of salts to the shallow ground water. Almost all irrigation water used in the Tulare Basin is either imported from the Sacramento/San Joaquin River Delta via the California Aqueduct or it originates from Sierra Nevada streams on the east side of the basin. Ground water is not widely used for irrigation throughout the study area, although certain areas in the basin (for example, the southern margin of Tulare Lake bed) use significant amounts for irrigation. The quality of water in the California Aqueduct generally is good, averaging approximately $300 \mathrm{mg} / \mathrm{L}$ of dissolved solids (California Department of Water Resources, 1992). Irrigation water originating from east-side streams also is of good quality, similar to the composition of water in the Kings and Kern Rivers. The salt load associated with applied irrigation water probably contributed less to the historically developed natural soil salinity than the saline, shallow ground-water conditions in the study area, particularly for those areas that have been irrigated for only a short time. However, the contribution of salts from irrigation water will be cumulative over time and must be considered in relation to the long-term salt-balance problems common in arid and semiarid regions where irrigated agriculture is practiced for a long time.

Shallow ground-water salinity, indicated by dissolved-solids concentrations, and concentrations of major ions for the three zones and their subzones are summarized in table 2. Statistical comparisons of salinities and constituent concentrations were made using the nonparametric Mann-Whitney test (Conover, 1980) at $\alpha=0.05$.

Shallow ground-water samples from the CR subzone of the alluvial-fan zone were significantly more saline (table 2 and fig. 2) and had higher concentrations of all major ions, except bicarbonate (table 2), compared to samples from the SN subzone. The CR subzone samples were dominated by sodium and sulfate, whereas sodium and bicarbonate and waters of mixed composition constituted the SN samples (fig. 3).

Similar results were found for shallow ground water from the basin zone. Samples from the BW subzone had significantly higher salinities (table 2 and fig. 2), calcium, magnesium, and sulfate (table 2) than samples from the BE subzone. Samples from the BW subzone were mainly sodium sulfate waters, and BE subzone samples had sodium as the dominant cation and no single dominant anion for most samples (fig. 4).

The shallow ground-water salinity and major-ion composition for the subzones associated with the alluvial-fan and basin deposits generally reflect the Coast Range (CR and BW) and Sierra Nevada (SN and $\mathrm{BE}$ ) origins of stream water and sediments, as well as origins of applied irrigation water. Stream water and sediments originating in the Coast Range generally are more saline and contain relatively higher concentrations of sulfate than those originating in the Sierra Nevada, reflecting the predominance of sediments derived from marine sedimentary rocks in the Coast Range and the predominance of igneous and metamorphic formations in the Sierra Nevada (Mendenhall and others, 1916; Davis and others, 1959; Wood and Davis, 1959; Davis, 1961; Davis and Coplen, 1989).

The predominance of sodium in shallow ground water relative to calcium in the recharging stream waters is caused in part by precipitation of slightly soluble calcium minerals such as calcite, aragonite, and gypsum. Preferential exchange of calcium in recharge and ground water for exchangeable sodium in soils and sediments also contributes to the relative increase in sodium in the shallow ground water.

Shallow ground-water salinities in the three subzones in the Tulare Lake zone differ 


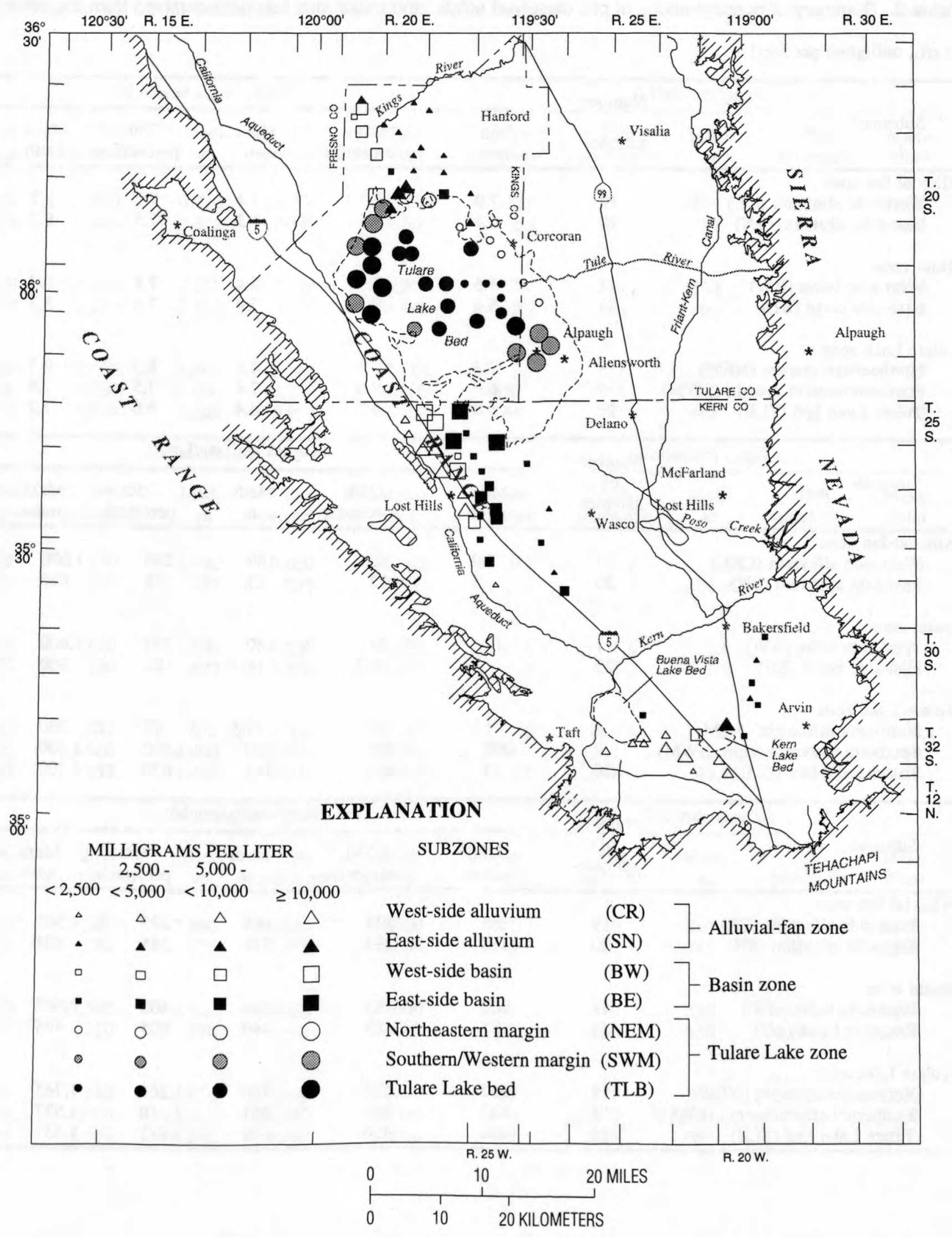

Figure 2. Distribution of salinity for all subzones in the Tulare Basin, California. 
Table 2. Summary of concentrations of $\mathrm{pH}$, dissolved solids, and major ions for water samples from the seven [mg/L, milligram per liter]

\begin{tabular}{|c|c|c|c|c|c|c|}
\hline \multirow[b]{2}{*}{ Subzone } & \multirow{2}{*}{$\begin{array}{c}\text { Number } \\
\text { of } \\
\text { samples }\end{array}$} & \multicolumn{5}{|c|}{$\mathrm{pH}$} \\
\hline & & $\begin{array}{l}\text { Mini- } \\
\text { mum }\end{array}$ & $\begin{array}{c}25 \text { th } \\
\text { percentile }\end{array}$ & $\begin{array}{l}\text { Medi- } \\
\text { an }\end{array}$ & $\begin{array}{c}75 \text { th } \\
\text { percentile }\end{array}$ & $\begin{array}{c}\text { Maxi- } \\
\text { mum }\end{array}$ \\
\hline \multicolumn{7}{|l|}{ Alluvial-fan zone } \\
\hline West-side alluvium (CR) & 19 & 7.0 & 7.3 & 7.4 & 7.7 & 8.2 \\
\hline East-side alluvium (SN) & 20 & 6.4 & 6.8 & 7.2 & 7.5 & 8.2 \\
\hline \multicolumn{7}{|l|}{ Basin zone } \\
\hline West-side basin (BW) & 11 & 5.6 & 6.9 & 7.4 & 7.8 & 8.0 \\
\hline East-side basin (BE) & 23 & 6.0 & 7.1 & 7.4 & 7.6 & 8.3 \\
\hline \multicolumn{7}{|l|}{ Tulare Lake zone } \\
\hline Northeastern margin (NEM) & 8 & 7.3 & 7.6 & 7.8 & 8.3 & 9.2 \\
\hline Southern/western margin (SWM) & 9 & 6.6 & 7.0 & 7.4 & 7.5 & 7.6 \\
\hline Tulare Lake bed (TLB) & 20 & 5.8 & 6.2 & 6.4 & 6.6 & 7.2 \\
\hline
\end{tabular}

\begin{tabular}{|c|c|c|c|c|c|c|}
\hline \multirow{2}{*}{ Subzone } & \multirow{2}{*}{$\begin{array}{l}\text { Number } \\
\text { of } \\
\text { samples }\end{array}$} & \multicolumn{5}{|c|}{ Magnesium (mg/L) } \\
\hline & & $\begin{array}{l}\text { Mini- } \\
\text { mum }\end{array}$ & $\begin{array}{c}25 \text { th } \\
\text { percentile }\end{array}$ & $\begin{array}{l}\text { Medi- } \\
\text { an }\end{array}$ & $\begin{array}{c}75 \text { th } \\
\text { percentile }\end{array}$ & $\begin{array}{c}\text { Maxi- } \\
\text { mum }\end{array}$ \\
\hline \multicolumn{7}{|l|}{ Alluvial-fan zone } \\
\hline West-side alluvium (CR) & 19 & 8.9 & 80 & 160 & 290 & 1,000 \\
\hline East-side alluvium (SN) & 20 & .5 & 12 & 25 & 93 & 630 \\
\hline \multicolumn{7}{|l|}{ Basin zone } \\
\hline West-side basin (BW) & 11 & 17 & 51 & 180 & 770 & 1,400 \\
\hline East-side basin (BE) & 23 & .4 & 7.2 & 18 & 82 & 300 \\
\hline \multicolumn{7}{|l|}{ Tulare Lake zone } \\
\hline Northeastern margin (NEM) & 8 & 1.1 & 10 & 17.5 & 47 & 280 \\
\hline Southern/western margin (SWM) & 9 & 260 & 505 & 940 & 1,500 & 1,800 \\
\hline Tulare Lake bed (TLB) & 20 & 13 & 123 & 315 & 670 & 1,700 \\
\hline
\end{tabular}

\begin{tabular}{|c|c|c|c|c|c|c|}
\hline \multirow{2}{*}{ Subzone } & \multirow{2}{*}{$\begin{array}{l}\text { Number } \\
\text { of } \\
\text { samples }\end{array}$} & \multicolumn{5}{|c|}{ Bicarbonate $(\mathrm{mg} / \mathrm{L})$} \\
\hline & & $\begin{array}{c}\text { Mini- } \\
\text { mum }\end{array}$ & $\begin{array}{c}25 \text { th } \\
\text { percentile }\end{array}$ & $\begin{array}{l}\text { Medi- } \\
\text { an }\end{array}$ & $\begin{array}{c}75 \text { th } \\
\text { percentile }\end{array}$ & $\begin{array}{c}\text { Maxi- } \\
\text { mum }\end{array}$ \\
\hline \multicolumn{7}{|l|}{ Alluvial-fan zone } \\
\hline West-side alluvium (CR) & 19 & 88 & 129 & 164 & 295 & 505 \\
\hline East-side alluvium (SN) & 20 & 110 & 213 & 379 & 585 & 804 \\
\hline \multicolumn{7}{|l|}{ Basin zone } \\
\hline West-side basin (BW) & 11 & 68 & 185 & 338 & 400 & 2,367 \\
\hline East-side basin (BE) & 23 & 81 & 189 & 449 & 805 & 495 \\
\hline \multicolumn{7}{|l|}{ Tulare Lake zone } \\
\hline Northeastern margin (NEM) & 8 & 437 & 575 & 780 & 1,260 & 1,745 \\
\hline Southern/western margin (SWM) & 9 & 423 & 583 & 861 & 1,210 & 1,537 \\
\hline Tulare Lake bed (TLB) & 20 & 234 & 450 & 612 & 882 & 1,537 \\
\hline
\end{tabular}




\begin{tabular}{|c|c|c|c|c|c|c|c|c|c|}
\hline \multicolumn{5}{|c|}{ Dissolved solids $(\mathrm{mg} / \mathrm{L})$} & \multicolumn{5}{|c|}{ Calcium $(\mathrm{mg} / \mathrm{L})$} \\
\hline $\begin{array}{l}\text { Mini- } \\
\text { mum }\end{array}$ & $\begin{array}{c}25 \text { th } \\
\text { percentile }\end{array}$ & $\begin{array}{c}\text { Medi- } \\
\text { an }\end{array}$ & $\begin{array}{c}75 \text { th } \\
\text { percentile }\end{array}$ & $\begin{array}{l}\text { Maxi- } \\
\text { mum }\end{array}$ & $\begin{array}{l}\text { Mini- } \\
\text { mum }\end{array}$ & $\begin{array}{c}25 \text { th } \\
\text { percentile }\end{array}$ & $\begin{array}{c}\text { Medi- } \\
\text { an }\end{array}$ & $\begin{array}{c}75 \text { th } \\
\text { percentile }\end{array}$ & $\begin{array}{l}\text { Maxi- } \\
\text { mum }\end{array}$ \\
\hline $\begin{array}{l}972 \\
176\end{array}$ & $\begin{array}{r}3,370 \\
609\end{array}$ & $\begin{array}{r}6,210 \\
961\end{array}$ & $\begin{array}{r}14,700 \\
3,330\end{array}$ & $\begin{array}{l}43,200 \\
14,200\end{array}$ & $\begin{array}{r}22.0 \\
6.4\end{array}$ & $\begin{array}{r}390 \\
31\end{array}$ & $\begin{array}{r}460 \\
67\end{array}$ & $\begin{array}{l}520 \\
158\end{array}$ & $\begin{array}{r}1,000 \\
450\end{array}$ \\
\hline $\begin{array}{r}1,520 \\
440\end{array}$ & $\begin{array}{l}5,080 \\
1,100\end{array}$ & $\begin{array}{l}7,230 \\
2,420\end{array}$ & $\begin{array}{r}25,700 \\
5,500\end{array}$ & $\begin{array}{l}91,900 \\
44,400\end{array}$ & $\begin{array}{l}37 \\
5.2\end{array}$ & $\begin{array}{r}220 \\
30\end{array}$ & $\begin{array}{r}330 \\
68\end{array}$ & $\begin{array}{l}660 \\
210\end{array}$ & $\begin{array}{l}900 \\
600\end{array}$ \\
\hline $\begin{array}{r}850 \\
7,180 \\
950\end{array}$ & $\begin{array}{r}1,340 \\
17,000 \\
3,890\end{array}$ & $\begin{array}{r}1,860 \\
28,000 \\
8,820\end{array}$ & $\begin{array}{r}5,460 \\
47,700 \\
10,900\end{array}$ & $\begin{array}{r}7,710 \\
63,600 \\
24,300\end{array}$ & $\begin{array}{c}3.1 \\
150 \\
44\end{array}$ & $\begin{array}{r}17 \\
240 \\
303\end{array}$ & $\begin{array}{r}22 \\
440 \\
485\end{array}$ & $\begin{array}{r}57 \\
515 \\
568\end{array}$ & $\begin{array}{r}95 \\
620 \\
770\end{array}$ \\
\hline \multicolumn{5}{|c|}{ Sodium $(\mathrm{mg} / \mathrm{L})$} & \multicolumn{5}{|c|}{ Potassium (mg/L) } \\
\hline $\begin{array}{l}\text { Mini- } \\
\text { mum }\end{array}$ & $\begin{array}{c}25 \text { th } \\
\text { percentile }\end{array}$ & $\begin{array}{c}\text { Medi- } \\
\text { an }\end{array}$ & $\begin{array}{c}\text { 75th } \\
\text { percentile }\end{array}$ & $\begin{array}{c}\text { Maxi- } \\
\text { mum }\end{array}$ & $\begin{array}{l}\text { Mini- } \\
\text { mum }\end{array}$ & $\begin{array}{c}25 \text { th } \\
\text { percentile }\end{array}$ & $\begin{array}{c}\text { Medi- } \\
\text { an }\end{array}$ & $\begin{array}{c}75 \text { th } \\
\text { percentile }\end{array}$ & $\begin{array}{c}\text { Maxi- } \\
\text { mum }\end{array}$ \\
\hline $\begin{array}{l}55 \\
22\end{array}$ & $\begin{array}{l}370 \\
102\end{array}$ & $\begin{array}{r}1,300 \\
225\end{array}$ & $\begin{array}{r}3,600 \\
835\end{array}$ & $\begin{array}{r}11,000 \\
3,900\end{array}$ & $\begin{array}{r}0.7 \\
.1\end{array}$ & $\begin{array}{r}2.2 \\
.7\end{array}$ & $\begin{array}{l}5.4 \\
1.0\end{array}$ & $\begin{array}{l}17 \\
3.2\end{array}$ & $\begin{array}{r}100 \\
11\end{array}$ \\
\hline $\begin{array}{r}130 \\
53\end{array}$ & $\begin{array}{l}620 \\
220\end{array}$ & $\begin{array}{r}1,500 \\
600\end{array}$ & $\begin{array}{l}7,200 \\
1,600\end{array}$ & $\begin{array}{l}30,000 \\
13,000\end{array}$ & $\begin{array}{l}.9 \\
.1\end{array}$ & $\begin{array}{l}1.4 \\
1.2\end{array}$ & $\begin{array}{l}2.6 \\
2.0\end{array}$ & $\begin{array}{l}9.3 \\
3.0\end{array}$ & $\begin{array}{l}21 \\
23\end{array}$ \\
\hline $\begin{array}{r}280 \\
1,900 \\
260\end{array}$ & $\begin{array}{r}442 \\
3,900 \\
653\end{array}$ & $\begin{array}{r}635 \\
8,400 \\
1,450\end{array}$ & $\begin{array}{r}1,700 \\
14,000 \\
2,200\end{array}$ & $\begin{array}{r}2,100 \\
18,000 \\
5,500\end{array}$ & $\begin{array}{c}.6 \\
11.5\end{array}$ & $\begin{array}{c}.8 \\
6.3\end{array}$ & $\begin{array}{l}1.5 \\
17 \\
12.5\end{array}$ & $\begin{array}{l}2.6 \\
74 \\
23\end{array}$ & $\begin{array}{l}8.1 \\
89 \\
35\end{array}$ \\
\hline \multicolumn{5}{|c|}{ Sulfate $(\mathrm{mg} / \mathrm{L})$} & \multicolumn{5}{|c|}{ Chloride $(\mathrm{mg} / \mathrm{L})$} \\
\hline $\begin{array}{l}\text { Mini- } \\
\text { mum }\end{array}$ & $\begin{array}{c}25 \text { th } \\
\text { percentile }\end{array}$ & $\begin{array}{l}\text { Medi- } \\
\text { an }\end{array}$ & $\begin{array}{c}\text { 75th } \\
\text { percentile }\end{array}$ & $\begin{array}{l}\text { Maxi- } \\
\text { mum }\end{array}$ & $\begin{array}{c}\text { Mini- } \\
\text { mum }\end{array}$ & $\begin{array}{c}25 \text { th } \\
\text { percentile }\end{array}$ & $\begin{array}{c}\text { Medi- } \\
\text { an }\end{array}$ & $\begin{array}{c}75 \text { th } \\
\text { percentile }\end{array}$ & $\begin{array}{c}\text { Maxi- } \\
\text { mum }\end{array}$ \\
\hline $\begin{array}{r}340 \\
16\end{array}$ & $\begin{array}{r}2,100 \\
92\end{array}$ & $\begin{array}{r}3,600 \\
175\end{array}$ & $\begin{array}{l}6,000 \\
1,500\end{array}$ & $\begin{array}{r}24,000 \\
8,500\end{array}$ & $\begin{array}{r}21 \\
5\end{array}$ & $\begin{array}{r}120 \\
31\end{array}$ & $\begin{array}{l}360 \\
115\end{array}$ & $\begin{array}{r}1,500 \\
308\end{array}$ & $\begin{array}{l}8,400 \\
1,900\end{array}$ \\
\hline $\begin{array}{r}740 \\
75\end{array}$ & $\begin{array}{r}2,500 \\
310\end{array}$ & $\begin{array}{r}4,100 \\
590\end{array}$ & $\begin{array}{r}14,000 \\
1,500\end{array}$ & $\begin{array}{l}20,000 \\
27,000\end{array}$ & $\begin{array}{r}140 \\
42\end{array}$ & $\begin{array}{l}340 \\
130\end{array}$ & $\begin{array}{l}550 \\
350\end{array}$ & $\begin{array}{l}5,900 \\
1,200\end{array}$ & $\begin{array}{r}44,000 \\
6,300\end{array}$ \\
\hline $\begin{array}{r}130 \\
3,300 \\
200\end{array}$ & $\begin{array}{r}152 \\
8,550 \\
2,300\end{array}$ & $\begin{array}{r}420 \\
13,000 \\
4,250\end{array}$ & $\begin{array}{r}1,880 \\
19,500 \\
6,250\end{array}$ & $\begin{array}{r}4,200 \\
34,000 \\
13,000\end{array}$ & $\begin{array}{r}58 \\
940 \\
99 \\
\end{array}$ & $\begin{array}{r}77 \\
2,800 \\
318 \\
\end{array}$ & $\begin{array}{r}150 \\
5,300 \\
1,050 \\
\end{array}$ & $\begin{array}{r}655 \\
9,400 \\
1,480\end{array}$ & $\begin{array}{r}1,300 \\
15,000 \\
3,700\end{array}$ \\
\hline
\end{tabular}




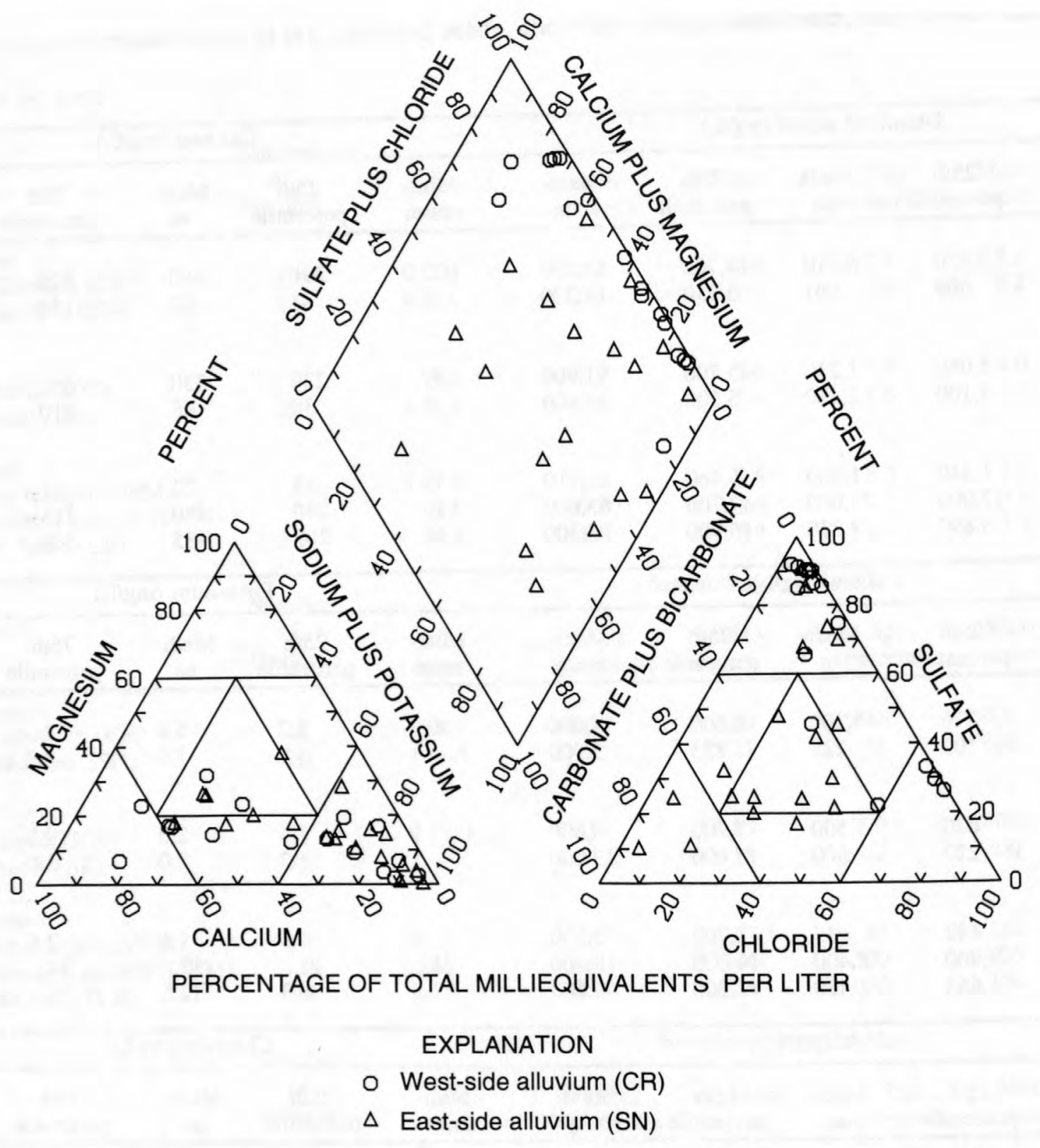

Figure 3. Major ion composition in water samples from the alluvial-fan zone: west-side alluvium (CR) and east-sid= alluvium (SN) subzones, Tulare Basin, California.

significantly; the SWM subzone has the highest salinities and the NEM subzone has the lowest salinities (table 2 and fig. 2). The SWM and TLB subzones are dominated by sodium sulfate waters (fig. 5). The NEM subzone also has sodium as the dominant cation, and bicarbonate is the predominant anion for 50 percent of the samples, sulfate for 25 percent of the samples, and the remaining samples had no dominant anion.

Shallow ground-water salinity in the Tulare Lake zone generally follows the soil mapping units used to delineate the three subzones. The highest salinity subzone, SWM, has sites on the southern and western margins of the Tulare Lake bed that consist of mostly Entisols with some Aridisols. Streamflow and sediments for this subzone are derived mainly from the Coast Range and from small ephemeral streams that originate in the Sierra Nevada, primarily Poso Creek, which probably is influenced by Miocene marine sedimentary rocks mapped in this area of the Sierra Nevada (pl. 1). Therefore, this subzone reflects the influence of marine sedimentary rocks that contribute larger 


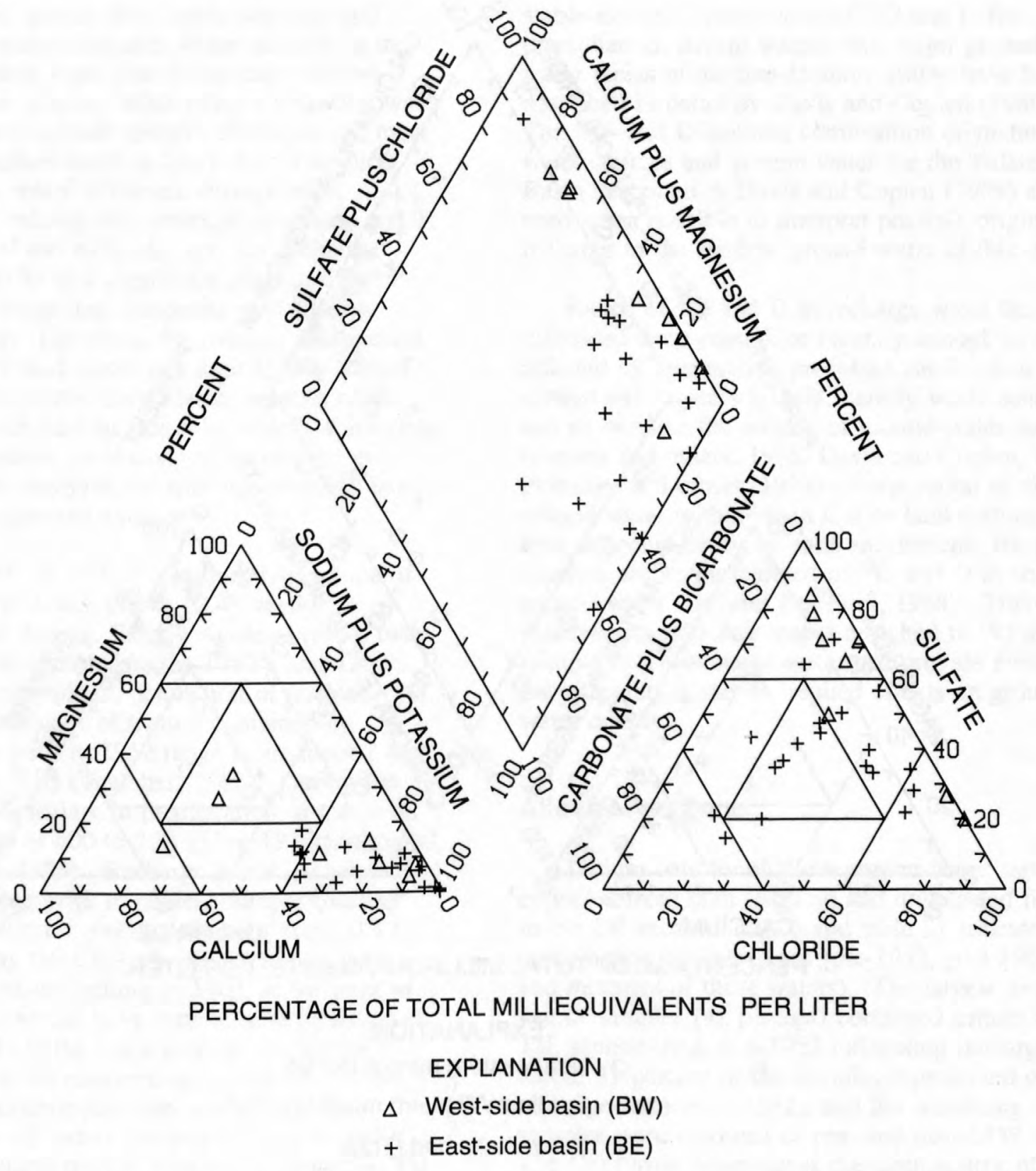

Figure 4. Major ion composition in water samples from the basin zone: west-side basin (BW) and east-side basin (BE) subzones, Tulare Basin, California.

amounts of salts relative to the igneous and metamorphic sediments influencing the less saline subzones. In addition, study sites in this subzone are on the southern and western margins of the lake where steamflows are intermittent and evaporative processes probably contribute to increases in shallow ground-water salinity. These processes are supported by isotopic data, discussed in the section on origin and isotopic composition of shallow ground water, and observations of salt crusts common on soils in nonirrigated fields in the Alpaugh area.

In contrast, the NEM subzone consists of fluvic Mollisols and is influenced mainly by the Kings and Tule Rivers on the east side of the basin. These rivers drain areas in the Sierra Nevada dominated by igneous and metamorphic formations 


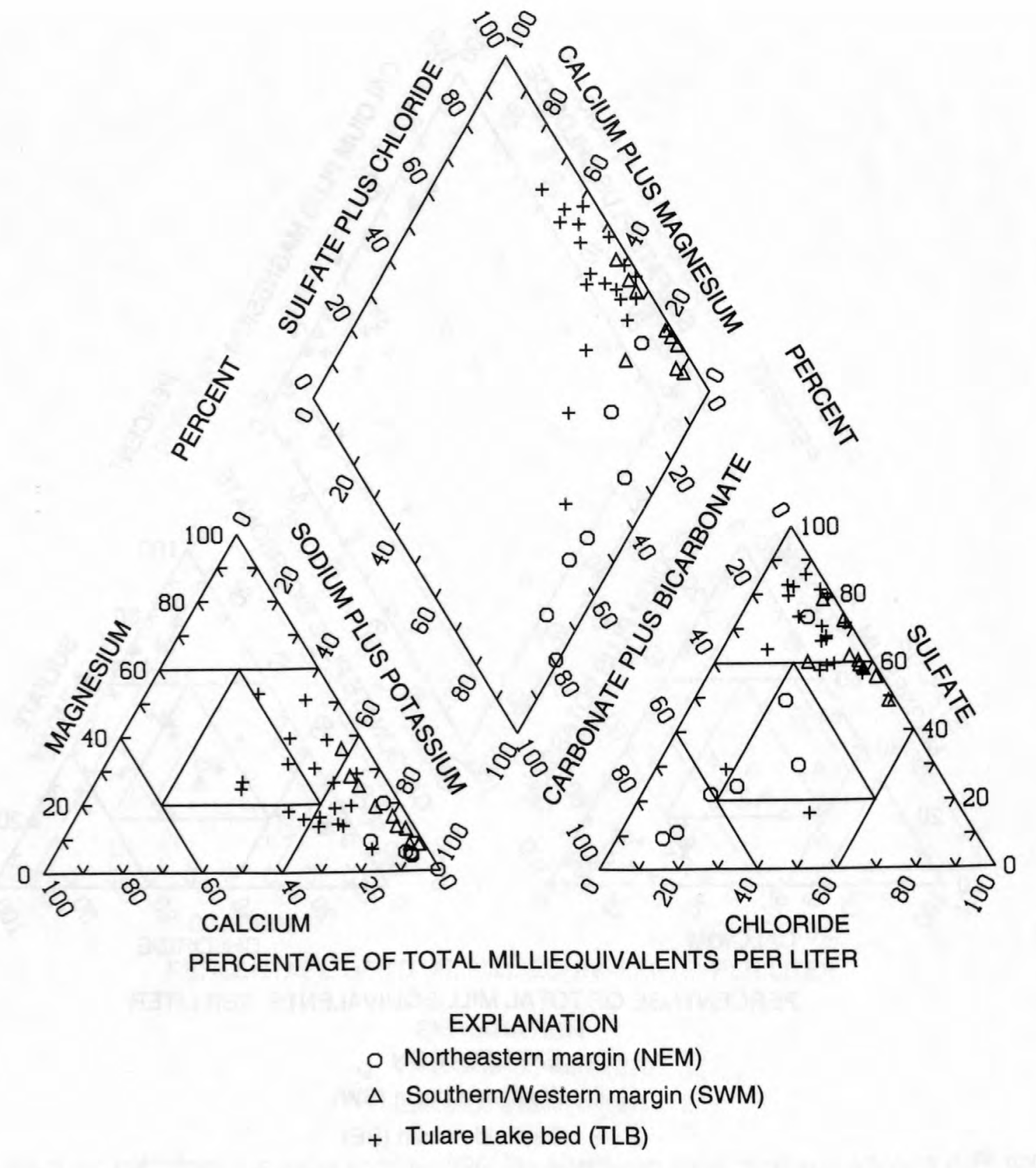

Figure 5. Major ion composition in water samples from the Tulare Lake zone: northeastern margin (NEM), southern/western margin (SWM), and Tulare Lake bed (TLB) subzones, Tulare Basin, California.

that yield mainly calcium/sodium bicarbonate type waters of low salinities (Mendenhall and others, 1916; Davis and Coplen, 1989). Flows from these rivers generally are much greater than that from the west-side rivers and, consequently, prevent the buildup of salts as observed in the SWM subzone.

The TLB subzone is a mixture of sediments from the Coast Range and Sierra Nevada; soils from this subzone generally are classified as aquic Mollisols, denoting high organic matter and saturated conditions prior to the drying of the lake. The intermediate salinity and major ion composition of samples from this zone reflect the mixture of stream and sediment sources.

\section{ORIGIN AND ISOTOPIC COMPOSITION OF SHALLOW GROUND WATER}

Although the origins of stream water and sediment have a primary influence on shallow 
ground-water quality, the origin, quantity, and quality of applied irrigation water recharging the shallow ground water also influences shallow ground-water quality. High salinity irrigation water adversely affects plant growth; consequently, most applied irrigation water is fairly low in salinity. However, as water infiltrates through soils, evaporation, mixing with preexisting ground water, weathering of soil minerals, and ion exchange reactions will have a significant effect on the salinity and major-ion composition of shallow ground water. Therefore, the isotopic composition of shallow ground water was used to help identify the age of the water, the different sources of the recharge water, and the possible processes affecting the water quality. In this study, ground-water samples were analyzed for tritium and stable isotope ratios of oxygen and hydrogen.

The levels of tritium, a radioactive isotope of hydrogen with a half-life of 12.43 years (International Atomic Energy Agency, 1981), rose in the environment during the 1950's and 1960's because of atmospheric detonation of nuclear weapons. Estimates of tritium contained in precipitation prior to 1952 range from about 2 to 8 tritium units (TU) (Thatcher, 1962). During the testing period, tritium in precipitation in the basin reached highs of 600 to $700 \mathrm{TU}$ in 1963 (estimated from Michel, 1989). Recharge water in the study area originating prior to nuclear-weapons testing would have tritium concentrations of about 0.3 to 1.0 TU during the 1989 sampling. In contrast, recharge water originating in 1963, at the peak of tritium input, would have tritium concentrations of about $160 \mathrm{TU}$ in the basin in 1989. A useful generalization for interpreting tritium data is that samples containing less than about $2 \mathrm{TU}$ are characteristic of waters infiltrating prior to 1952 ; waters containing tritium greater than about $10 \mathrm{TU}$ are characteristic of surface waters recharging after 1952; and waters containing tritium between 2 and $10 \mathrm{TU}$ represent mixtures of recharge waters originating before and after 1952 (Dubrovsky and others, 1991). Although imprecise, these breakdowns provide a useful approximation for initial interpretation of ages and mixtures of recharge waters.

Stable-isotopic ratios of oxygen-18 $\left({ }^{18} \mathrm{O}\right)$ relative to oxygen-16 $\left({ }^{16} \mathrm{O}\right)$, and deuterium (D) relative to hydrogen are reported relative to the Vienna-Standard Mean Ocean Water in delta $(\delta)$ notation as parts per thousand (permil) (Craig, 1961). The distribution and processes affecting the stable-isotopic composition of ${ }^{18} \mathrm{O}$ and $\mathrm{D}$ for precipitation, stream waters, and major groundwater facies in the San Joaquin Valley have been described in detail by Davis and Coplen (1989). The ${ }^{18} \mathrm{O}$ - and D-isotopic composition (signature) of water sources and ground water for the Tulare Basin described in Davis and Coplen (1989) are used when possible to interpret possible origins of recharge to the shallow ground water in this study.

Ratios of ${ }^{18} \mathrm{O}$ and $\mathrm{D}$ in recharge water that infiltrated deep enough or recently enough to not be affected by evaporative processes can be used as conservative tracers to help identify water sources and to estimate the mixing of ground-water sources (Coplen and others, 1985; Davis and Coplen, 1989; Plummer and others, 1993). Evaporation of shallow ground water within about $4 \mathrm{ft}$ of land surface can lead to accumulation of salts and isotopic fractionation and to enrichment of ${ }^{18} \mathrm{O}$ and $\mathrm{D}$ in shallow ground water (Deverel and Fujii, 1988). Therefore, shallow ground water that is enriched in ${ }^{18} \mathrm{O}$ and $\mathrm{D}$ relative to the recharge water can provide evidence for evaporation and its implied effects on groundwater quality.

\section{Alluvial-Fan Zone}

Tritium data for shallow ground-water samples collected from both irrigated and unirrigated fields in the CR subzone (fig. 6 and table 3) indicate a combination of water ages (pre-1952, post-1952, and mixtures of these waters). The largest percentage of samples (42 percent) contained tritium $>10$ TU, representing post-1952 infiltrating recharge. About 21 percent of the samples represented older recharge water (pre-1952), and the remaining samples were mixtures of pre- and post- 1952 water. The California Aqueduct is the main source of irrigation water for the CR subzone near the town of Lost Hills in northwestern Kern County (fig. 1) and could account for the elevated tritium concentrations in the collected samples. In contrast, tritium concentrations in samples from the CR subzone sites near Kern and Buena Vista Lake beds in the southern part of Kern County generally are lower than those in samples collected in northwestern Kern County. These concentrations reflect the combined use of water from the California Aqueduct, the San Joaquin and Kern Rivers, and pre-1952 ground water for irrigation.

Seventy percent of the shallow ground-water samples from the SN subzone contained tritium $>10$ 
Table 3. Summary of concentrations of tritium, delta oxygen-18, and delta deuterium for water samples from

[TU, tritium units; $\mathrm{mg} / \mathrm{L}$, milligram per liter]

\begin{tabular}{|c|c|c|c|c|c|c|}
\hline \multirow[b]{2}{*}{ Subzone } & \multirow{2}{*}{$\begin{array}{l}\text { Number } \\
\text { of } \\
\text { samples }\end{array}$} & \multicolumn{5}{|c|}{ Tritium (TU) } \\
\hline & & $\begin{array}{l}\text { Mini- } \\
\text { mum }\end{array}$ & $\begin{array}{c}25 \text { th } \\
\text { percentile }\end{array}$ & $\begin{array}{c}\text { Medi- } \\
\text { an }\end{array}$ & $\begin{array}{c}\text { 75th } \\
\text { percentile }\end{array}$ & $\begin{array}{c}\text { Maxi- } \\
\text { mum }\end{array}$ \\
\hline \multicolumn{7}{|l|}{ Alluvial-fan zone } \\
\hline West-side alluvium (CR) & 19 & 1.8 & 4.7 & 9.4 & 11 & 16 \\
\hline East-side alluvium (SN) & 20 & 5.3 & 9.7 & 14 & 20 & 45 \\
\hline \multicolumn{7}{|l|}{ Basin zone } \\
\hline West-side basin (BW) & 11 & 1.2 & 1.8 & 8.4 & 9.7 & 15 \\
\hline East-side basin (BE) & 23 & 1.8 & 5.0 & 8.1 & 11 & 26 \\
\hline \multicolumn{7}{|l|}{ Tulare Lake zone } \\
\hline Northeastern margin (NEM) & 8 & 4.7 & 6.6 & 18 & 26 & 34 \\
\hline Southern/western margin (SWM) & 9 & 1.8 & 2.0 & 2.8 & 8.1 & 11 \\
\hline Tulare Lake bed (TLB) & 20 & 1.8 & 4.1 & 9.2 & 15 & 31 \\
\hline
\end{tabular}

TU, indicating recharge after 1952 , and the remaining samples reflected waters of mixed ages (fig. 6). Most of the samples from the northern part of the basin contained tritium $>10 \mathrm{TU}$ and are probably recharge water from the Kings River and from unconfined, upper ground water on the east side of the basin (M.C. Welker and N.M.

Dubrovsky, U.S. Geological Survey, written commun., 1990). The remaining samples (30 percent) in Kern County are probably affected by a mixture of California Aqueduct water and confined and unconfined ground water originating from the east side of the basin (fig. 6).

The stable isotope $\left(\delta^{18} \mathrm{O}\right.$ and $\left.\delta \mathrm{D}\right)$ data for the CR subzone samples (fig. 7) indicate an evaporative trend with enrichment in ${ }^{18} \mathrm{O}$ and $\mathrm{D}$, as indicated by a linear $\left(\mathrm{R}^{2}=0.86\right)$ deviation from the global meteoric water line with a slope of 3.88 and an intercept of -36.2 . In general, the most enriched samples with $\delta^{18} \mathrm{O}$ greater than about -8 permil correspond to the samples with the highest salinities.

Water in the California Aqueduct (sampled at Panoche Road in western Fresno County) had a $\delta^{18} \mathrm{O}$ of $-9.69 \pm 0.40$ permil and a $\delta \mathrm{D}$ of $-72.6 \pm$ 2.08 (mean and standard deviation) for 12 samples collected during the late 1980's (S.J. Deverel, U.S.
Geological Survey, written commun., 1987). This data point falls almost exactly on the evaporative trend line (fig. 7), close to the global meteoric water line and to Davis and Coplen's (1989) local groundwater line, indicating its possible use as irrigation water in the area. Deverel and Fujii (1988) reported a slope of 4.28 and an intercept of -20 for $\delta^{18} \mathrm{O}$ and $\delta \mathrm{D}$ data for shallow ground water from three agricultural fields in the central part of the western San Joaquin Valley affected by evaporation. This evaporative trend line also intersects the California Aqueduct water $\delta^{18} \mathrm{O}$ and $\delta \mathrm{D}$.

Differences in slopes and intercepts between Deverel and Fujii's (1988) data and the CR subzone data probably are related to processes other than evaporation that are affecting the isotopic signatures of the waters. Another complication is that ground water from depths greater than about $500 \mathrm{ft}$ in the basin trough and west side of the Tulare Basin has a median $\delta^{18} \mathrm{O}$ of -9.6 (37 samples) (M.C. Welker and N.M. Dubrovsky, U.S. Geological Survey, written commun., 1990), similar to that of water from the California Aqueduct. This similarity does not allow differentiation of shallow ground-water origin in this area based solely on stable isotope composition.

The $\delta^{18} \mathrm{O}$ and $\delta \mathrm{D}$ data for the SN subzone generally fall close to the global meteoric water 


\begin{tabular}{|c|c|c|c|c|c|c|c|c|c|}
\hline \multicolumn{5}{|c|}{ Delta oxygen-18 (permil) } & \multicolumn{5}{|c|}{ Delta deuterium (permil) } \\
\hline $\begin{array}{l}\text { Mini- } \\
\text { mum }\end{array}$ & $\begin{array}{c}25 \text { th } \\
\text { percentile }\end{array}$ & $\begin{array}{l}\text { Medi- } \\
\text { an }\end{array}$ & $\begin{array}{c}75 \text { th } \\
\text { percentile }\end{array}$ & $\begin{array}{c}\text { Maxi- } \\
\text { mum }\end{array}$ & $\begin{array}{l}\text { Mini- } \\
\text { mum }\end{array}$ & $\begin{array}{c}25 \text { th } \\
\text { percentile }\end{array}$ & $\begin{array}{l}\text { Medi- } \\
\text { an }\end{array}$ & $\begin{array}{c}\text { 75th } \\
\text { percentile }\end{array}$ & $\begin{array}{c}\text { Maxi- } \\
\text { mum }\end{array}$ \\
\hline-10.90 & -9.55 & -8.90 & -6.85 & -3.60 & -79.5 & -75.5 & -70.5 & -62.5 & -52.0 \\
\hline-13.05 & -12.10 & -11.38 & -10.03 & -9.25 & -95.5 & -89.4 & -86.8 & -78.1 & -72.5 \\
\hline-10.70 & -9.35 & -8.05 & -6.70 & -.10 & -87.0 & -75.5 & -67.0 & -62.5 & -38.0 \\
\hline-12.10 & -10.95 & -9.45 & -8.50 & -5.65 & -94.5 & -85.0 & -75.0 & -67.5 & -59.5 \\
\hline-11.25 & -10.98 & -10.85 & -9.80 & -7.60 & -89.0 & -83.5 & -82.3 & -76.3 & -62.5 \\
\hline-8.15 & -6.80 & -5.30 & -3.30 & -1.75 & -71.0 & -62.8 & -55.5 & -46.5 & -39.5 \\
\hline-9.05 & -8.46 & -6.38 & -4.91 & -3.70 & -76.5 & -72.6 & -61.8 & -57.9 & -47.5 \\
\hline
\end{tabular}

line and to the local ground-water line of Davis and Coplen (1989), indicating little evaporative concentration of shallow ground water. These data compare well with the $\delta^{18} \mathrm{O}$ and $\delta \mathrm{D}$ data for the Kings River facies (1a, 1b, 1c) that was used by Davis and Coplen (1989) in conjunction with other ground-water data from the San Joaquin Valley to define their local ground-water line and to reflect the common east-side origin of ground water. Differences between the stable-isotope composition for the $\mathrm{SN}$ and $\mathrm{CR}$ subzones probably result from the relative contributions of water of different isotopic signatures supplied from the Sierra Nevada and Coast Range in the respective areas.

\section{Basin Zone}

Tritium data for samples from the BW and BE subzones have similar breakdowns with most samples for both subzones ( 57 and 55 percent, respectively) having concentrations between 2 and $10 \mathrm{TU}$, indicating mixtures of pre- and post-1952 water (fig. 6 and table 3). Water in the California Aqueduct and water originating from east-side streams probably account for the elevated tritium (>10 TU) found in 30 and 18 percent of the samples from the BW and BE subzones, respectively. The remaining samples from each subzone represent pre-1952 water and probably indicate the use of deeper ground water for irrigation. Tritium data for this zone, therefore, reflect the extensive use of multiple sources of water for irrigation.

The $\delta^{18} \mathrm{O}$ and $\delta \mathrm{D}$ data for the BW subzone (fig. 8 ) indicate enrichment from evaporation $\left(R^{2}=0.92\right.$, slope of 4.12, intercept of -36.1), especially for the samples with $\delta^{18} \mathrm{O}$ greater than approximately -8 permil. The sample from site 7B3 (fig. 1) in this subzone is the most enriched $\left(\delta^{18} \mathrm{O}=-0.10\right.$ permil) and the most saline $(91,900 \mathrm{mg} / \mathrm{L}$ dissolved solids) of all samples collected during the study. This sample also contains tritium $<2$ TU and consists of highly evaporated pre-1952 water, possibly derived from the lower aquifer. The $\delta^{18} \mathrm{O}$ and $\delta \mathrm{D}$ data for the BE subzone are similar to the BW-subzone data (fig. 8) with an evaporative trend line $\left(\mathrm{R}^{2}=0.87\right)$ that has a slope of 5.68 and an intercept of -22.3 . The results for samples with $\delta^{18} \mathrm{O}$ less than approximately -8 permil are similar to the data for the Kings River facies, plotting close to the local ground-water line identified by Davis and Coplen (1989). 


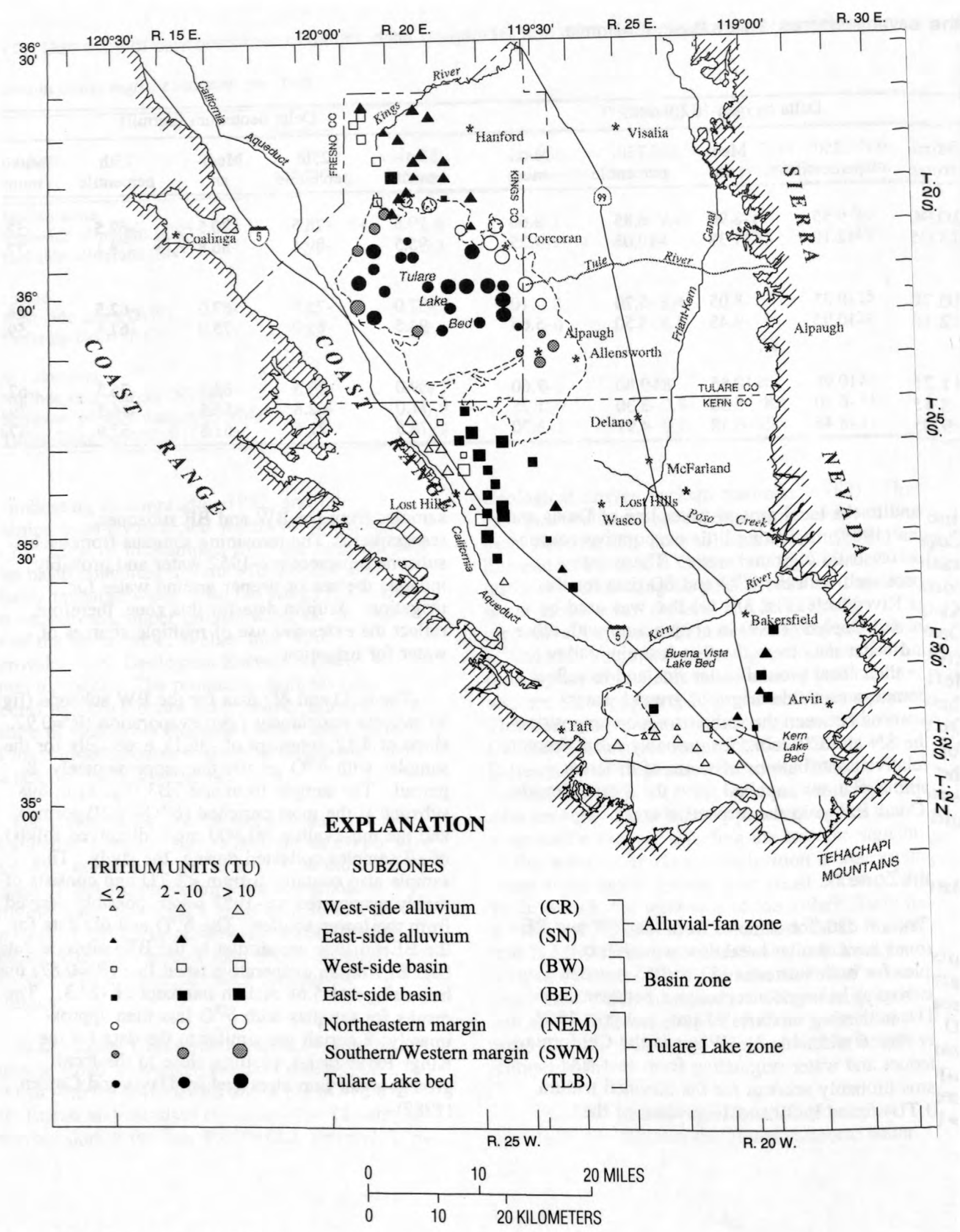

Figure 6. Distribution of tritium for all subzones in the Tulare Basin, California. 


\section{Tulare Lake Zone}

Most samples from sites in the NEM subzone generally reflect post -1952 water; 63 percent of the samples had $>10$ TU (fig. 6). Data for $\delta^{18} \mathrm{O}$ and $\delta \mathrm{D}$ are significantly correlated $\left(R^{2}=0.95\right.$, slope of 6.48 , intercept of -12.8). One sample is slightly enriched in both isotopes (fig. 9) and has a tritium concentration of $6.3 \mathrm{TU}$, probably indicating the influence of older evaporated water mixing with Sierran stream water. The remainder of the samples have $\delta^{18} \mathrm{O}$ values less than approximately -9 permil, similar to the Kings River facies, and they plot close to the local ground-water line identified by Davis and Coplen (1989) (fig. 9). These results reflect the major influence that irrigating with and recharge from Sierra Nevada stream water have on shallow ground-water quality in this area.

Concentrations of tritium in TLB subzone samples also reflect a major influence of irrigating with Sierra Nevada stream water and California Aqueduct water, with 50 percent of the samples representing post-1952 water, 10 percent pre-1952 water, and 40 percent mixtures (fig. 6). Groundwater resources suitable for irrigation are present on the eastern and northern margins of the lakebed; some ground water from the lower Kings River alluvial fan also is used for irrigating the lakebed. These waters might be the source of pre-1952

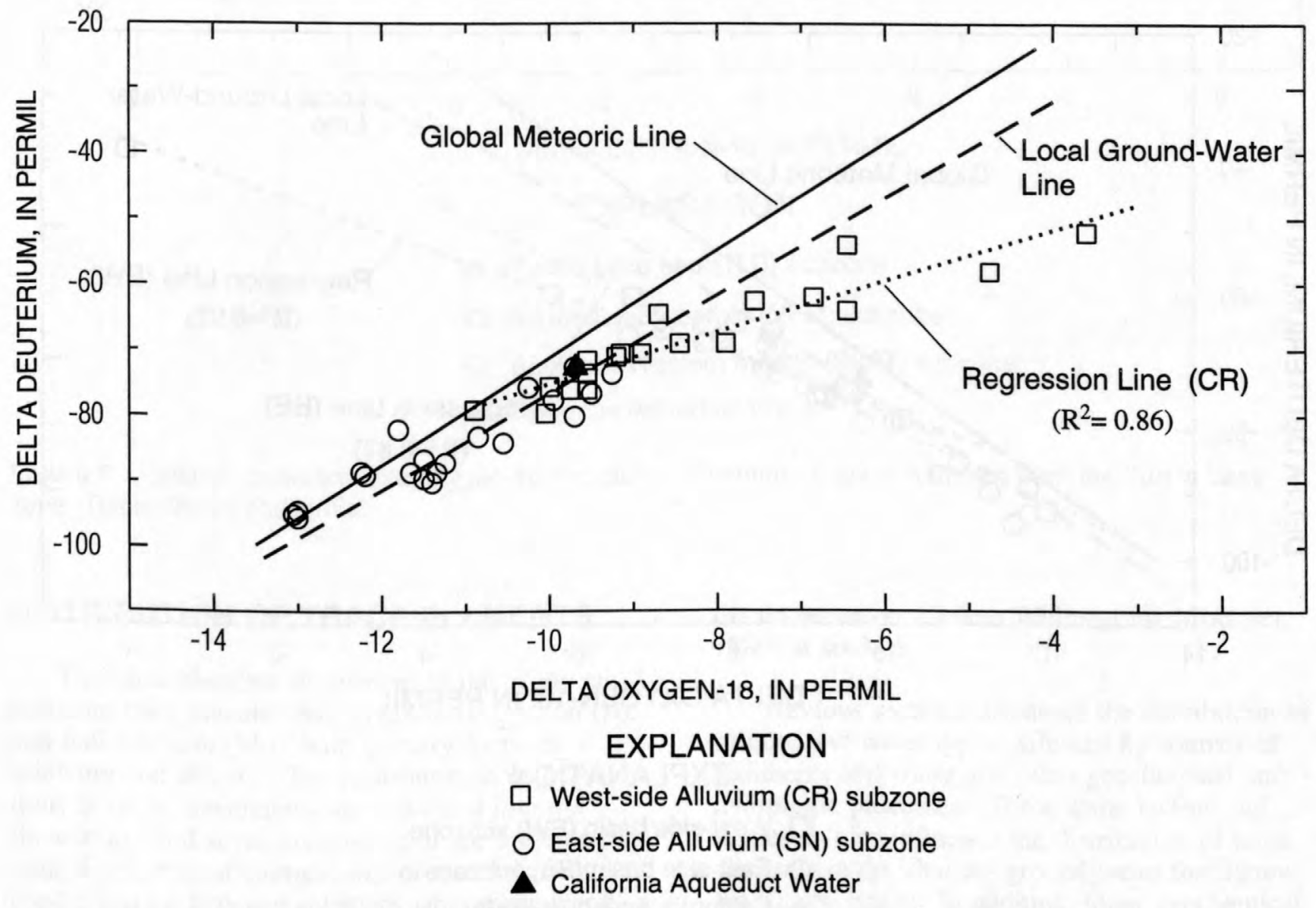

Figure 7. Relation between delta oxygen-18 and delta deuterium for water samples from the alluvial-fan zone, Tulare Basin, California. 
shallow ground water and could contribute to the mixtures of pre- and post-1952 shallow ground water sampled in this subzone. The $\delta^{18} \mathrm{O}$ and $\delta \mathrm{D}$ data for samples from this subzone plot on a highly evaporated trend line $\left(R^{2}=0.94\right.$, slope of 4.72 , intercept of -32.6) (fig. 9), resulting in significantly higher salinities for samples from this subzone relative to the NEM subzone.

In contrast to the other two subzones in the Tulare Lake zone, tritium concentrations for samples from the SWM subzone indicate only one sample (11 percent) of post-1952 water; the remaining samples consisted of 22 percent pre-1952 water and 67 percent mixtures of pre- and post1952 shallow ground water (fig. 6). Four of the 11 samples from the southeastern margin of the lakebed contain 1.8 to $2.8 \mathrm{TU}$, which reflects the significant use of older ground water for irrigation in this area. Samples from the SWM subzone also were enriched in ${ }^{18} \mathrm{O}$ and $\mathrm{D}$, and the data plot along an evaporative trend line $\left(R^{2}=0.97\right.$, slope of 4.72 , intercept of -31.1), almost identical to the TLB subzone, but contained the two most highly evaporated samples (sites 15M1 and 31D2) in the Tulare Lake zone (fig. 9). The highly evaporated nature of the shallow ground water in this subzone is reflected by the significantly higher salinities (median of $28,000 \mathrm{mg} / \mathrm{L}$ dissolved solids) in shallow ground water in this subzone relative to all other subzones in the study.

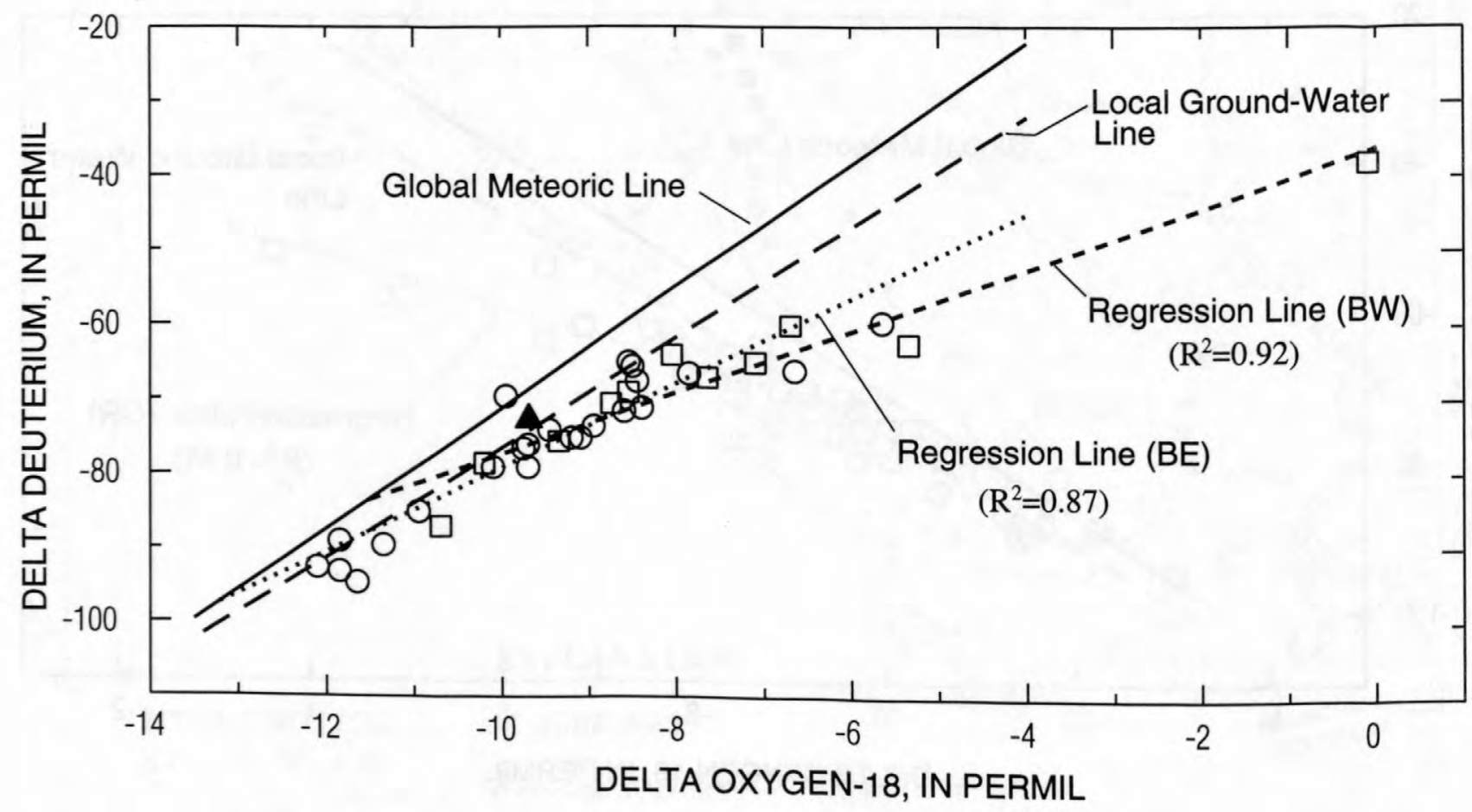

EXPLANATION

West-side basin (BW) subzone

East-side basin (BE) subzone

$\Delta$ California Aqueduct Water Figure 8. Relation between delta oxygen-18 and delta deuterium for water samples from the basin zone, Tulare
Basin, California. 


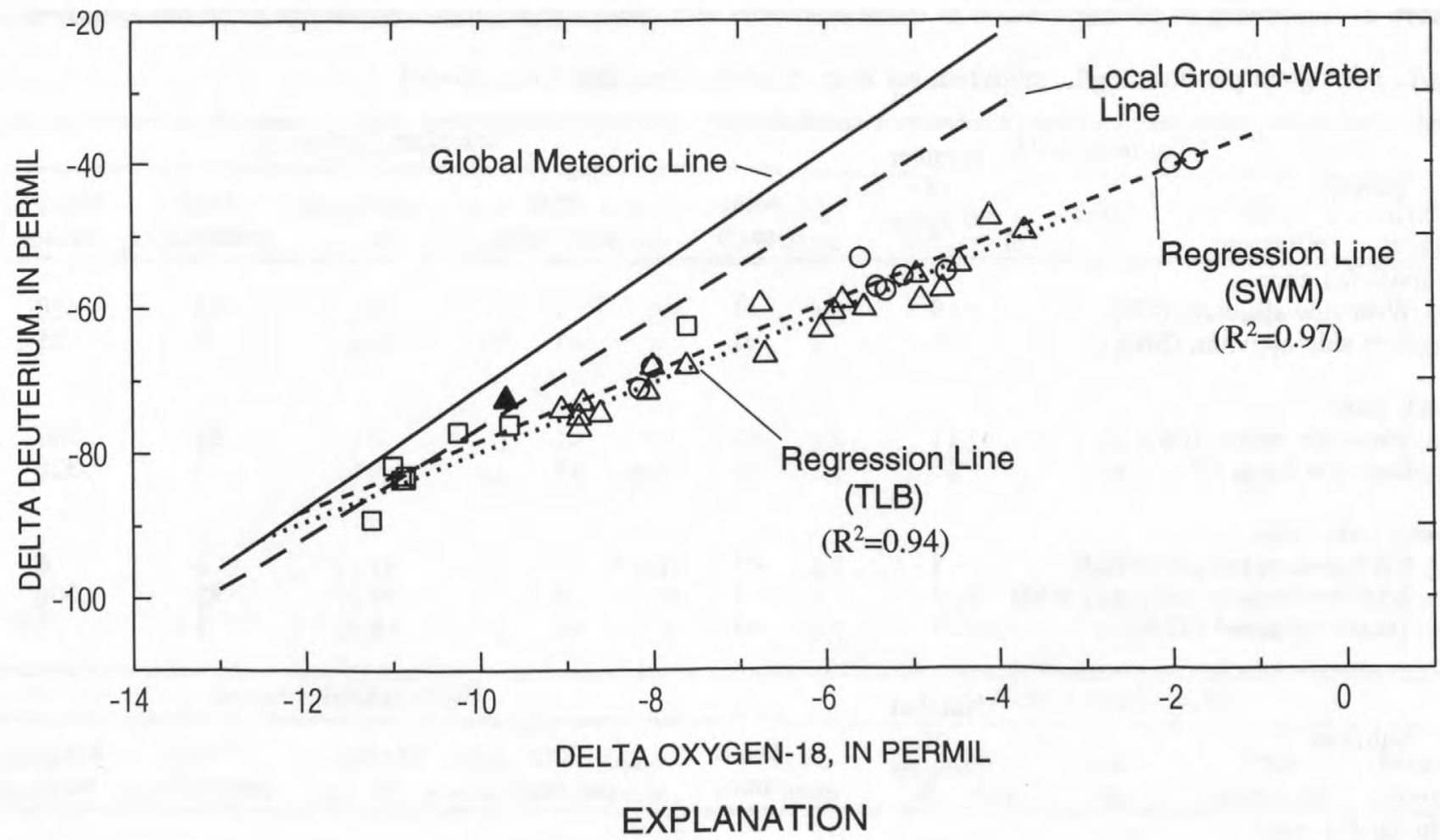

$\triangle$ Tulare Lake bed (TLB) subzone

口 Northeastern margin (NEM) subzone

O Southern/Western margin (SWM) subzone

- California Aqueduct Water

Figure 9. Relation between delta oxygen-18 and delta deuterium for water samples from the Tulare Lake zone, Tulare Basin, California.

\section{DISTRIBUTION OF TRACE ELEMENTS}

The trace elements of concern in this study are selenium (Se), arsenic (As), uranium (U), boron (B), and molybdenum (Mo), with primary focus on selenium and arsenic. The concentration distributions of these constituents are separated into the three zones and seven subzones and are presented in table 4. Statistical comparisons of trace-element concentrations between subzones were made using the nonparametric Mann-Whitney test (Conover, 1980) at $\alpha=0.05$.

Previous sections discussed the distribution of salinity and water types affected by sources of sediments and water and other geochemical and hydrologic processes. These same factors and processes also influence the distribution of trace elements in the shallow ground water throughout the Tulare Basin. In addition, other geochemical 
Table 4. Summary of concentrations of trace elements and oxidation-reduction indicators for water samples $[\mu \mathrm{g} / \mathrm{L}$, microgram per liter; $\mathrm{mg} / \mathrm{L}$, milligram per liter; <, amount less than value shown]

\begin{tabular}{|c|c|c|c|c|c|c|}
\hline \multirow[b]{2}{*}{ Subzone } & \multirow{2}{*}{$\begin{array}{l}\text { Number } \\
\text { of } \\
\text { samples }\end{array}$} & \multicolumn{5}{|c|}{ Selenium $(\mu \mathrm{g} / \mathrm{L})$} \\
\hline & & $\begin{array}{c}\text { Mini- } \\
\text { mum }\end{array}$ & $\begin{array}{c}25 \text { th } \\
\text { percentile }\end{array}$ & $\begin{array}{l}\text { Medi- } \\
\text { an }\end{array}$ & $\begin{array}{c}75 \text { th } \\
\text { percentile }\end{array}$ & $\begin{array}{c}\text { Maxi- } \\
\text { mum }\end{array}$ \\
\hline $\begin{array}{l}\text { Alluvial-fan zone } \\
\text { West-side alluvium (CR) }\end{array}$ & & & & & & \\
\hline $\begin{array}{l}\text { West-side alluvium (CR) } \\
\text { East-side alluvium (SN) }\end{array}$ & $\begin{array}{l}19 \\
20\end{array}$ & $\begin{array}{l}<1 \\
<1\end{array}$ & $\begin{array}{r}1 \\
<1\end{array}$ & $\begin{array}{r}8 \\
<1\end{array}$ & $\begin{array}{r}58 \\
1\end{array}$ & $\begin{array}{r}520 \\
25\end{array}$ \\
\hline & & & & & & \\
\hline West-side basin (BW) & 11 & $<1$ & $<1$ & 3 & 21 & 240 \\
\hline East-side basin (BE) & 23 & $<1$ & $<1$ & $<1$ & 5 & 320 \\
\hline Tulare Lake zone & & & & & & \\
\hline Northeastern margin (NEM) & 8 & $<1$ & $<1$ & $<1$ & 2 & 4 \\
\hline Southern/western margin (SWM) & 9 & 1 & 2 & 34 & 195 & 1,000 \\
\hline Tulare Lake bed (TLB) & 20 & $<1$ & $<1$ & $<1$ & 1 & 2.0 \\
\hline \multirow[b]{2}{*}{ Subzone } & \multirow{2}{*}{$\begin{array}{c}\text { Number } \\
\text { of } \\
\text { samples }\end{array}$} & \multicolumn{5}{|c|}{ Boron $(\mu \mathrm{g} / \mathrm{L})$} \\
\hline & & $\begin{array}{l}\text { Mini- } \\
\text { mum }\end{array}$ & $\begin{array}{c}25 \text { th } \\
\text { percentile }\end{array}$ & $\begin{array}{l}\text { Medi- } \\
\text { an }\end{array}$ & $\begin{array}{c}75 \text { th } \\
\text { percentile }\end{array}$ & $\begin{array}{c}\text { Maxi- } \\
\text { mum }\end{array}$ \\
\hline \multicolumn{7}{|l|}{ Alluvial-fan zone } \\
\hline West-side alluvium (CR) & 19 & 320 & 2,200 & 6,900 & 22,000 & 73,000 \\
\hline East-side alluvium (SN) & 20 & 70 & 135 & 570 & 1,530 & 13,000 \\
\hline \multicolumn{7}{|l|}{ Basin zone } \\
\hline West-side basin (BW) & 11 & 1,500 & 2,300 & 9,800 & 36,000 & 64,000 \\
\hline East-side basin (BE) & 23 & 340 & 630 & 1,600 & 6,100 & 70,000 \\
\hline \multicolumn{7}{|l|}{ Tulare Lake zone } \\
\hline Northeastern margin (NEM) & 8 & 370 & 1,300 & 2,000 & 3,850 & 4,500 \\
\hline Southern/western margin (SWM) & 9 & 4,900 & 8,650 & 14,000 & 19,500 & 27,000 \\
\hline Tulare Lake bed (TLB) & 20 & 660 & 1,880 & 3,200 & 5,930 & 14,000 \\
\hline \multirow{2}{*}{ Subzone } & \multirow{2}{*}{$\begin{array}{l}\text { Number } \\
\text { of } \\
\text { samples }\end{array}$} & \multicolumn{5}{|c|}{ Manganese $(\mu \mathrm{g} / \mathrm{L})$} \\
\hline & & $\begin{array}{c}\text { Mini- } \\
\text { mum }\end{array}$ & $\begin{array}{c}25 \text { th } \\
\text { percentile }\end{array}$ & $\begin{array}{l}\text { Medi- } \\
\text { an }\end{array}$ & $\begin{array}{c}\text { 75th } \\
\text { percentile }\end{array}$ & $\begin{array}{c}\text { Maxi- } \\
\text { mum }\end{array}$ \\
\hline \multicolumn{7}{|l|}{ Alluvial-fan zone } \\
\hline West-side alluvium (CR) & 19 & $<1$ & 10 & 20 & 40 & 710 \\
\hline East-side alluvium (SN) & 20 & $<1$ & 13 & 215 & 1,060 & 3,100 \\
\hline \multicolumn{7}{|l|}{ Basin zone } \\
\hline West-side basin (BW) & 11 & 5 & 40 & 270 & 690 & 2,000 \\
\hline East-side basin (BE) & 23 & $<1$ & 10 & 50 & 180 & 1,200 \\
\hline \multicolumn{7}{|l|}{ Tulare Lake zone } \\
\hline Northeastern margin (NEM) & 8 & 5 & 8.7 & 76.5 & 238 & 640 \\
\hline Southern/western margin (SWM) & 9 & 160 & 225 & 520 & 3,700 & 10,000 \\
\hline Tulare Lake bed (TLB) & 20 & 540 & 3,330 & 7,950 & 17,500 & 67,000 \\
\hline
\end{tabular}


from the seven subzones, Tulare Basin, California

\begin{tabular}{|c|c|c|c|c|c|c|c|c|c|}
\hline \multicolumn{5}{|c|}{ Arsenic $(\mu \mathrm{g} / \mathrm{L})$} & \multicolumn{5}{|c|}{ Uranium $(\mu \mathrm{g} / \mathrm{L})$} \\
\hline $\begin{array}{l}\text { Mini- } \\
\text { mum }\end{array}$ & $\begin{array}{c}25 \text { th } \\
\text { percentile }\end{array}$ & $\begin{array}{c}\text { Medi- } \\
\text { an }\end{array}$ & $\begin{array}{c}\text { 75th } \\
\text { percentile }\end{array}$ & $\begin{array}{c}\text { Maxi- } \\
\text { mum }\end{array}$ & $\begin{array}{l}\text { Mini- } \\
\text { mum }\end{array}$ & $\begin{array}{c}25 \text { th } \\
\text { percentile }\end{array}$ & $\begin{array}{c}\text { Medi- } \\
\text { an }\end{array}$ & $\begin{array}{c}\text { 75th } \\
\text { percentile }\end{array}$ & $\begin{array}{c}\text { Maxi- } \\
\text { mum }\end{array}$ \\
\hline $\begin{array}{l}<1 \\
<1\end{array}$ & $\begin{array}{l}1 \\
2\end{array}$ & $\begin{array}{l}1 \\
6\end{array}$ & $\begin{array}{r}3 \\
47\end{array}$ & $\begin{array}{l}60 \\
87\end{array}$ & $\begin{array}{l}8.5 \\
3\end{array}$ & $\begin{array}{l}21 \\
7.0\end{array}$ & $\begin{array}{l}42 \\
18\end{array}$ & $\begin{array}{l}62 \\
71\end{array}$ & $\begin{array}{r}210 \\
2,500\end{array}$ \\
\hline $\begin{array}{l}1 \\
1\end{array}$ & $\begin{array}{l}2 \\
5\end{array}$ & $\begin{array}{r}5 \\
17\end{array}$ & $\begin{array}{r}6 \\
46\end{array}$ & $\begin{array}{r}13 \\
870\end{array}$ & $\begin{array}{l}3.3 \\
1.1\end{array}$ & $\begin{array}{l}15 \\
22\end{array}$ & $\begin{array}{l}16.5 \\
73\end{array}$ & $\begin{array}{l}113 \\
150\end{array}$ & $\begin{array}{l}730 \\
960\end{array}$ \\
\hline $\begin{array}{l}3 \\
3 \\
3\end{array}$ & $\begin{array}{r}9 \\
4 \\
14\end{array}$ & $\begin{array}{l}17 \\
19 \\
20.5\end{array}$ & $\begin{array}{r}141 \\
113 \\
72\end{array}$ & $\begin{array}{r}2,600 \\
230 \\
230\end{array}$ & $\begin{array}{c}4.3 \\
31 \\
1.3\end{array}$ & $\begin{array}{c}13 \\
38 \\
3.0\end{array}$ & $\begin{array}{c}40 \\
160 \\
10.1\end{array}$ & $\begin{array}{r}106 \\
3,050 \\
40\end{array}$ & $\begin{array}{r}450 \\
5,400 \\
350\end{array}$ \\
\hline \multicolumn{5}{|c|}{ Molybdenum $(\mu \mathrm{g} / \mathrm{L})$} & \multicolumn{5}{|c|}{ Nitrate $(\mathrm{mg} / \mathrm{L}$ as $\mathrm{N})$} \\
\hline $\begin{array}{l}\text { Mini- } \\
\text { mum }\end{array}$ & $\begin{array}{c}25 \text { th } \\
\text { percentile }\end{array}$ & $\begin{array}{l}\text { Medi- } \\
\text { an }\end{array}$ & $\begin{array}{c}\text { 75th } \\
\text { percentile }\end{array}$ & $\begin{array}{l}\text { Maxi- } \\
\text { mum }\end{array}$ & $\begin{array}{l}\text { Mini- } \\
\text { mum }\end{array}$ & $\begin{array}{c}25 \text { th } \\
\text { percentile }\end{array}$ & $\begin{array}{l}\text { Medi- } \\
\text { an }\end{array}$ & $\begin{array}{c}\text { 75th } \\
\text { percentile }\end{array}$ & $\begin{array}{l}\text { Maxi- } \\
\text { mum }\end{array}$ \\
\hline $\begin{array}{r}50 \\
1\end{array}$ & $\begin{array}{r}110 \\
7\end{array}$ & $\begin{array}{r}300 \\
40\end{array}$ & $\begin{array}{l}490 \\
193\end{array}$ & $\begin{array}{l}1,800 \\
2,500\end{array}$ & $\begin{array}{l}<.10 \\
<.10\end{array}$ & $\begin{array}{l}.80 \\
.94\end{array}$ & $\begin{array}{l}3.7 \\
8.0\end{array}$ & $\begin{array}{l}17 \\
26\end{array}$ & $\begin{array}{l}185 \\
100\end{array}$ \\
\hline $\begin{array}{l}12 \\
14\end{array}$ & $\begin{array}{l}30 \\
50\end{array}$ & $\begin{array}{l}220 \\
160\end{array}$ & $\begin{array}{r}1,000 \\
640\end{array}$ & $\begin{array}{r}1,700 \\
15,000\end{array}$ & $\begin{array}{r}.29 \\
<.10\end{array}$ & $\begin{array}{l}.50 \\
.60\end{array}$ & $\begin{array}{l}5.6 \\
4.4\end{array}$ & $\begin{array}{l}25 \\
24\end{array}$ & $\begin{array}{l}95 \\
56\end{array}$ \\
\hline $\begin{array}{r}20 \\
480 \\
17\end{array}$ & $\begin{array}{r}45 \\
990 \\
31\end{array}$ & $\begin{array}{r}86 \\
2,000 \\
95\end{array}$ & $\begin{array}{r}153 \\
7,000 \\
288\end{array}$ & $\begin{array}{r}600 \\
14,000 \\
410\end{array}$ & $\begin{array}{r}.14 \\
.11 \\
<.10\end{array}$ & $\begin{array}{l}4.0 \\
2.5 \\
<.10\end{array}$ & $\begin{array}{l}12 \\
20 \\
<.10\end{array}$ & $\begin{array}{l}21 \\
24 \\
\quad .28\end{array}$ & $\begin{array}{c}37 \\
27 \\
1.2\end{array}$ \\
\hline \multicolumn{10}{|c|}{ Iron $(\mu \mathrm{g} / \mathrm{L})$} \\
\hline $\begin{array}{l}\text { Mini- } \\
\text { mum }\end{array}$ & & $\begin{array}{c}25 \text { th } \\
\text { percentile }\end{array}$ & & $\begin{array}{c}\text { Medi- } \\
\text { ian }\end{array}$ & & $\begin{array}{c}75 \text { th } \\
\text { percentile }\end{array}$ & & $\begin{array}{c}\text { Maxi- } \\
\text { mum }\end{array}$ & \\
\hline $\begin{array}{r}<3 \\
4\end{array}$ & & $\begin{array}{r}30 \\
6\end{array}$ & & $\begin{array}{r}40 \\
8\end{array}$ & & $\begin{array}{l}60 \\
55\end{array}$ & & $\begin{array}{r}220 \\
8,100\end{array}$ & \\
\hline $\begin{array}{r}20 \\
4\end{array}$ & & $\begin{array}{l}30 \\
20\end{array}$ & & $\begin{array}{r}100 \\
30\end{array}$ & & $\begin{array}{r}190 \\
50\end{array}$ & & $\begin{array}{r}850 \\
5,200\end{array}$ & \\
\hline $\begin{array}{r}5 \\
40 \\
7\end{array}$ & & $\begin{array}{r}10 \\
100 \\
282\end{array}$ & & $\begin{array}{r}20 \\
220 \\
4,000\end{array}$ & & $\begin{array}{r}103 \\
1,140 \\
37,500\end{array}$ & & $\begin{array}{r}520 \\
8,200 \\
210,000\end{array}$ & \\
\hline
\end{tabular}


processes such as redox and adsorption significantly affect the solubility and distribution of the trace elements of concern in this study.

Identification of areas with elevated concentrations of total trace elements in soils and sediments often is used to make an initial delineation of areas with potential ground-water quality problems. The concentration of trace elements in ground water depends on the biogeochemical processes affecting and controlling trace element solubility and the solid-phase associations of the elements in soils and sediments (Deverel and Fujii, 1990).

The solid-phase associations of trace elements in soils and sediments also will influence its availability and potential release over time. For example, the presence of soluble evaporite minerals, such as thenardite, that contain coprecipitated selenate [Se(VI)] (Presser and others, 1990; Presser and Swain, 1990) in unsaturated soils represents a very labile form and source of selenium to ground water if recharge water undersaturated with thenardite percolates through the soil. In contrast, arsenate $[\mathrm{As}(\mathrm{V})]$ adsorbed on and subsequently occluded by iron or manganese oxyhydroxide minerals represents a form of arsenic not easily released to ground water. Results of analyses of total trace element content of soils and sediments often are used to indicate potential source areas; however, the forms in which trace elements are present and the geochemical and hydrologic setting in which they occur will determine the solubility and availability of trace elements to ground-water systems.

The trace elements of concern in this study, except boron, exist in more than one oxidation state in natural environments and, therefore, are affected by electron transfer (redox) reactions. The solubility and geochemical behavior of redoxsensitive trace elements are dependent on their oxidation state. For example, reduction of $\mathrm{Se}(\mathrm{VI})$, the most oxidized and soluble selenium species, to elemental selenium [Se(0)], a more reduced, less soluble species of selenium, reduces the solubility and mobility of selenium in ground water because of the relative solubilities of these selenium forms. In contrast, reduction of $\mathrm{As}(\mathrm{V})$ to arsenite [As(III)] usually increases the solubility of arsenic because $\mathrm{As}(\mathrm{V})$ generally is more strongly adsorbed than As(III) (Crecelius and others, 1986). The redox status of the ground-water environment, therefore, affects the oxidation state of redox-sensitive trace element species, which in turn affects their solubilities.

A major electron-donating process in soils and sediments is the microbial oxidation of reduced organic carbon. Most unsaturated soils contain enough oxygen to maintain oxidizing conditions, and oxygen generally is the terminal electron acceptor for microbial oxidation. Under watersaturated conditions, the oxygen supply rate can be slower than the oxygen demand, and anaerobic or reducing conditions can develop (Reddy and Patrick, 1983). In poorly aerated soils where the supply of oxygen is limited by the rate of diffusion, anoxic microsites also can develop. In the absence of oxygen, other soil constituents act as the electron acceptor and are reduced.

Bohn and others (1979) list the principal electron acceptors in soils according to their tendency to be reduced as indicated by the equilibrium potentials of half-reactions at $\mathrm{pH}$ 7: $\mathrm{O}_{2}$ $>$ nitrate $\left(\mathrm{NO}_{3}\right)>$ manganese oxide $\left(\mathrm{MnO}_{2}\right)>$ iron oxyhydroxide $(\mathrm{FeOOH})>$ sulfate $\left(\mathrm{SO}_{4}\right)>$ hydrogen $(\mathrm{H})$. Thus in theory, after a ground-water system has been depleted of oxygen, nitrate will be the next major electron acceptor used by microorganisms until depleted, and the reduction sequence will continue as long as the carbon source is not limiting and the appropriate microbial population is present.

These same principles apply to redox-sensitive trace elements. The potential redox sequence or redox ladder (Scott and Morgan, 1990) of elements of concern in this study is shown in figure 10 as critical redox potentials. These critical redox 
potentials represent the potential above and below which the oxidized and reduced species, respectively, should predominate under equilibrium conditions.

Concentrations of redox sensitive elements such as nitrate, manganese, and iron in shallow ground water indicate the redox status of ground water. The presence of significant concentrations of nitrate in the absence of oxygen indicates slightly oxidized conditions because nitrate will poise the redox status of the system at a relatively high redox potential (fig. 10). Once most of the nitrate has been reduced, the redox potential tends to decrease and the next energetically favorable electron acceptor will be reduced. Under oxidized and neutral-to-alkaline $\mathrm{pH}$ conditions, manganese and iron are present in their higher oxidation states as relatively insoluble minerals (for example, manganese and iron oxyhydroxides). The solubilities of manganese and iron increase as reducing conditions develop because of transformations of manganese and iron to their more soluble (II) valence states (fig. 10) . Therefore, an abundance of nitrate in ground water indicates relatively oxidized conditions and precludes the presence of high concentrations of either aqueous manganese or iron at neutral to alkaline $\mathrm{pH}$. Conversely, high concentrations of manganese generally indicate mildly reduced conditions, and high concentrations of iron indicate somewhat more reduced conditions (fig. 10).

\section{Selenium}

Shallow ground-water concentrations of selenium in the study area range from less than the detection limit of 1 to $1,000 \mu \mathrm{g} / \mathrm{L}$ (table 4). The U.S. Environmental Protection Agency (USEPA) $(1987,1988)$ classifies selenium as a priority pollutant with an aquatic-life criteria of $5 \mu \mathrm{g} / \mathrm{L}$. At least 30 samples exceeded the USEPA aquatic-life criteria, and 3 samples with concentrations of $<10$ $\mu \mathrm{g} / \mathrm{L}$ also may have exceeded the $5 \mu \mathrm{g} / \mathrm{L}$ criterion (table 8, at back of report).
The areal distribution of selenium in shallow ground water indicates significantly higher concentrations in the $\mathrm{CR}, \mathrm{BW}$, and SWM subzones (table 4 and fig. 11) than in the other four subzones. The $\mathrm{CR}$ and $\mathrm{BW}$ subzones also have elevated concentrations of selenium in soils. The distribution of selenium in shallow ground water is strongly influenced by sources of selenium, selenium concentrations in soil, evaporation of shallow ground water, and redox conditions.

Tidball and others (1990) present data that indicate the distribution of selenium in surface soils (0 to 12 in.) throughout the San Joaquin Valley (complete soil analysis reported by Wilson and others, 1990). The highest selenium concentrations in the study area, those $>0.88 \mathrm{mg} / \mathrm{kg}$ (the 99 th percentile of soil concentrations for the entire valley), are west of the town of Lost Hills.

Concentrations of soil selenium generally decrease east of Lost Hills and probably influence CR and BW subzone sampling sites in this vicinity. The areas west of Lost Hills are adjacent to parts of the Temblor Range of the Coast Range where Miocene, Eocene, and lower Cretaceous marine sedimentary rocks are exposed (California Division of Mines and Geology, 1969).

The areas south, southwest, and southeast of Buena Vista Lake bed also contain elevated concentrations of soil selenium that range from 0.36 to $0.59 \mathrm{mg} / \mathrm{kg}$ (90 to 95 th percentile) and from 0.18 to $0.36 \mathrm{mg} / \mathrm{kg}$ ( 70 to 90 th percentile) (Tidball and others, 1990; Wilson and others, 1990) and probably affect the $\mathrm{CR}$ and BW subzone sampling sites in this vicinity. These areas are adjacent to areas in the San Emigdio and Tehachapi Mountains where marine sedimentary rocks of Eocene and Miocene age also are exposed. Marine sedimentary rocks of the Keryenhagen Formation of Eocene and Oligocene age and the Moreno Formation of Upper Cretaceous and Paleocene age have been identified as selenium sources in the Coast Range farther north in the vicinity of Panoche and Cantua Creeks (Presser and others, 1990; Presser and Swain, 1990) and in the Monterey Formation of Miocene and 


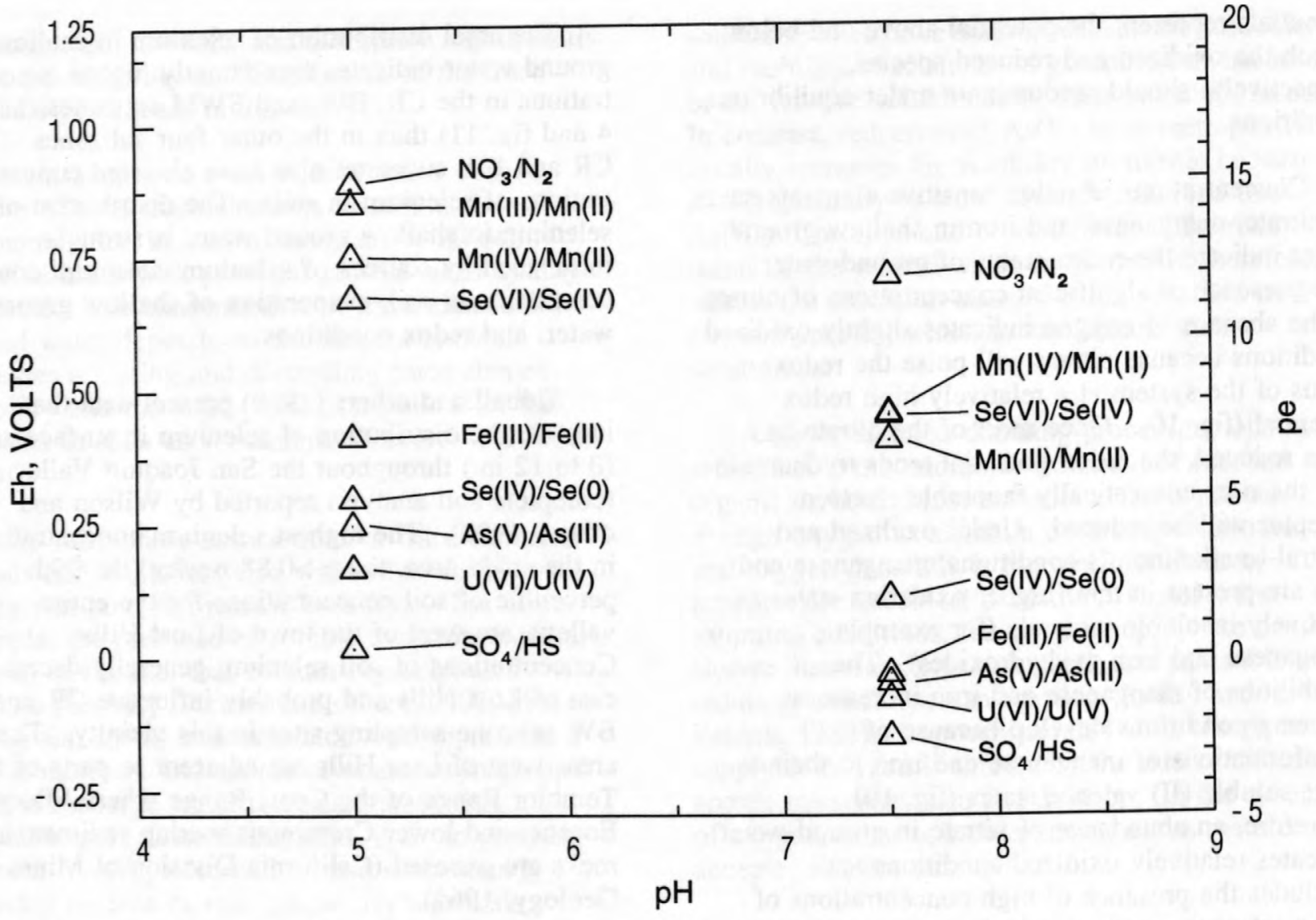

\section{Data Sources:}

$\mathrm{NO}_{3} / \mathrm{N}_{2}$-Stumm and Morgan, 1981; $\mathrm{Mn}(\mathrm{IV}) / \mathrm{Mn}(\mathrm{II}), \mathrm{Mn}$ (III)/Mn(II), $\mathrm{Fe}(\mathrm{III}) / \mathrm{Fe}(\mathrm{II}), \mathrm{As}(\mathrm{V}) / \mathrm{As}(\mathrm{III})$, and $\mathrm{SO}_{4} / \mathrm{HS}$ -

Ball and Nordstrom, 1991; $\mathrm{Se}(\mathrm{VI}) / \mathrm{Se}(\mathrm{IV})$ and $\mathrm{Se}(\mathrm{IV}) / \mathrm{Se}(\mathrm{O})$ - Cowan, 1988; U(VI)/U(IV) - estimated from Langmuir, 1978.

\section{Assumptions:}

ratios of activities of oxidized and reduced aqueous species and solid phases are equal to unity; activity of $\mathrm{Se}(\mathrm{IV})\left(\mathrm{HSeO}_{\overline{3}}\right)$ for $\mathrm{Se}(\mathrm{IV}) / \mathrm{Se}(0)$ equals $10^{-6}$; fugacity of gases, except $\mathrm{CO}_{2}$, is 1 atmosphere; solid phases: $\mathrm{MnO}_{2}(\mathrm{~s})[\mathrm{Mn}(\mathrm{IV})], \mathrm{MnOOH}(\mathrm{s})[\mathrm{Mn}(\mathrm{III})], \mathrm{Fe}(\mathrm{OH})_{3}(\mathrm{~s})[\mathrm{Fe}(\mathrm{III})]$; aqueous $\mathrm{U}(\mathrm{VI})$ and $\mathrm{U}(\mathrm{IV})$ present predominantly as carbonyl ( $P_{\mathrm{CO}_{2}}=10^{-2}$ atmosphere) and hydroxyl complexes, respectively (Langmiur, 1978).

$\begin{array}{llll}\mathrm{Eh} & \text { redox potential } & \mathrm{As}(\mathrm{III}) & \text { arsenite } \\ \mathrm{NO}_{3} & \text { nitrate } & \mathrm{Se}(\mathrm{VI}) & \text { selenate } \\ \mathrm{N}_{2} & \text { nitrogen gas } & \mathrm{Se}(\mathrm{IV}) & \text { selenite } \\ \mathrm{SO}_{4} & \text { sulfate } & \mathrm{Se}(0) & \text { elemental selenium } \\ \mathrm{HS} & \text { hydrogen sulfide } & \mathrm{U}(\mathrm{VI}) & \text { uranyl } \\ \mathrm{Mn}(\mathrm{II}) & \text { manganese (II) } & \mathrm{U}(\mathrm{IV}) & \text { uranous } \\ \mathrm{Mn}(\mathrm{III}) & \text { manganese(III) } & \mathrm{MnO}(\mathrm{s}) & \text { pyrolusite } \\ \mathrm{Mn}(\mathrm{IV}) & \text { manganese (IV) } & \mathrm{MnOOH}(\mathrm{s}) & \text { manganite } \\ \mathrm{Fe}(\mathrm{III}) & \text { ferric iron } & \mathrm{Fe}(\mathrm{OF})_{3}(\mathrm{~s}) & \text { ferrihydrite } \\ \mathrm{Fe}(\mathrm{II}) & \text { ferrous iron } & \mathrm{P}_{\mathrm{CO} 2} & \text { carbon dioxide partial pressure } \\ \mathrm{As}(\mathrm{V}) & \text { arsenate } & & \end{array}$

Figure 10. Critical redox potential at $\mathrm{pH} 5$ and 7.5 for redox couples pertinent to this study, Tulare Basin, California. 


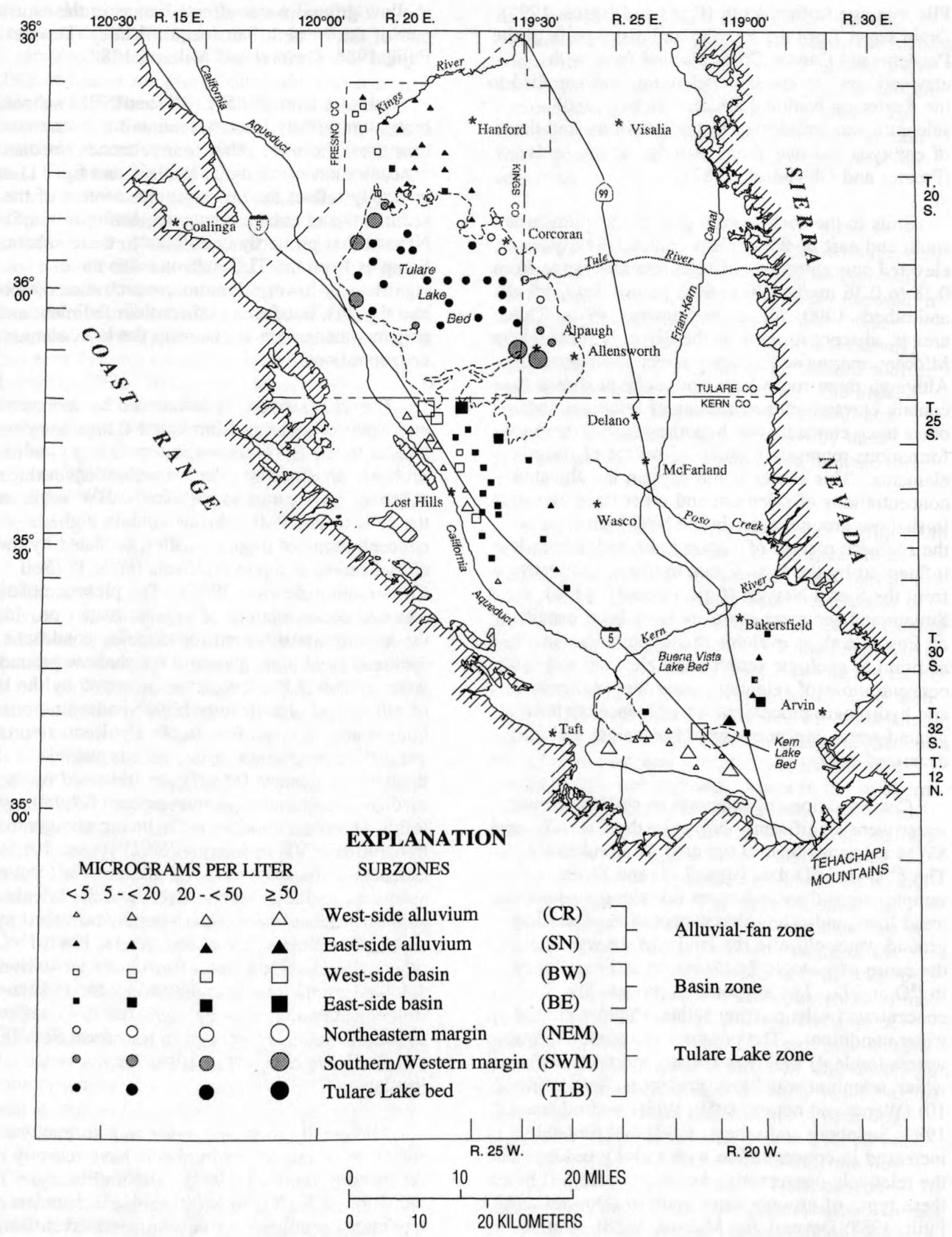

Figure 11. Distribution of selenium for each zone and subzone, Tulare Basin, California. 
Pliocene age further south (Piper and Isaacs, 1995). Drain water from the interfan and distal parts of the Panoche and Cantua Creek alluvial fans, with elevated concentrations of selenium, was supplied to the Kesterson National Wildlife Refuge until selenium was implicated in the deformity and death of embryos and hatchlings of wild aquatic birds (Presser and Ohlendorf, 1987).

Soils in the southeastern part of the study area south and east of Bakersfield contain slightly elevated concentrations of selenium that range from 0.18 to $0.36 \mathrm{mg} / \mathrm{kg}$ (70 to 90th percentile) (Tidball and others, 1990; Wilson and others, 1990). This area is adjacent to parts of the Sierra Nevada where Miocene marine sedimentary rocks are exposed. Although these rocks have not yet been shown to contain elevated concentrations of selenium and other trace elements, we hypothesize that these formations represent a potential source of trace elements. This source could explain the elevated concentrations of selenium and other trace elements in shallow ground water in the SWM subzone on the southern margin of Tulare Lake bed, which is influenced by the Poso Creek drainage originating from the Sierra Nevada (figs. 1 and 11; pl. 1). Stream and sediment samplers have been installed on Poso Creek to evaluate this hypothesis. In addition to geologic sources and elevated soil concentrations of selenium, other biogeochemical and hydrologic processes also influence shallow ground-water concentrations of selenium and are discussed below.

Concentrations of selenium in shallow ground water were significantly higher in the $\mathrm{CR}, \mathrm{BW}$, and SWM subzones than in the other four subzones. The $\delta^{18} \mathrm{O}$ and $\delta \mathrm{D}$ data (figs. 7, 8, and 9) for samples from these subzones fall along evaporativetrend lines, indicating that evaporation of shallow ground water close to the land surface was likely the cause of isotopic fractionation and enrichment in ${ }^{18} \mathrm{O}$ and $\mathrm{D}$. The evaporative process also concentrated salts causing saline, shallow groundwater conditions. The presence of nitrate in these waters (table 4) indicates redox conditions under which selenium was likely present as $\mathrm{Se}(\mathrm{VI})$ (fig. 10) (Weres and others, 1989; White and others, 1991; Steinberg and others, 1992) and probably increased in concentration with salinity because of the relatively conservative behavior of Se(VI) in these types of ground-water systems (Deverel and Fujii, 1988; Deverel and Millard, 1988). Similar effects of these processes on salinity and selenium, present as $\mathrm{Se}(\mathrm{VI})$, were previously reported for shallow ground-water-affected areas in the central part of the western San Joaquin Valley (Deverel and Fujii, 1988; Deverel and Millard, 1988).

Samples from the SN, BE, and NEM subzones have significantly lower selenium concentrations than those from the other four subzones (median concentration of $<1 \mu \mathrm{g} / \mathrm{L}$ ) (table 4 and fig. 11) and generally reflect the low selenium content of the sediments and stream water originating in the Sierra Nevada that primarily contribute to these subzones. Samples from the TLB subzone also have significantly lower selenium concentrations (table 4 and fig. 11), but factors others than sediment and stream-water origin are causing the low selenium concentrations.

The TLB subzone is influenced by sediments and water originating from Coast Range sources similar to the BW subzone, but reducing conditions probably are limiting selenium solubility in this subzone. In contrast to soils in the BW subzones, the soils in the TLB subzone contain higher concentrations of organic matter, reflected by their classification as aquic Mollisols (table 1) (Soil Conservation Service, 1975). The presence of elevated concentrations of organic matter provides the appropriate substrate for reducing conditions. Reduced conditions observed for shallow ground water in the TLB subzone are indicated by the lack of nitrate and significantly higher concentrations of both manganese and iron (table 4). Reduction of tetravalent or trivalent manganese to soluble divalent manganese [Mn(II)], as indicated by the median concentration of manganese of $7,950 \mu \mathrm{g} / \mathrm{L}$ (table 4), reflects conditions reducing enough to transform Se(VI) to selenite [Se(IV)] (fig. 10). Selenate is the most oxidized and soluble form of selenium, and reduction to Se(IV) limits selenium solubility because $\mathrm{Se}(\mathrm{IV})$ is strongly adsorbed by soils and sediments (Neal and others, 1987; Fio and others, 1991). Reduction of insoluble ferric iron to soluble ferrous iron, as indicated by the median iron concentration of $4,000 \mu \mathrm{g} / \mathrm{L}$ (table 4 ), reflects conditions reducing enough to transform $\mathrm{Se}(\mathrm{VI})$ and $\mathrm{Se}$ (IV) to $\mathrm{Se}(\mathrm{O})$ (fig. 10), which is very insoluble.

Microbially mediated redox transformations of selenium in anoxic environments have recently been reviewed (Oremland, 1994). Dissimililatory reduction of $\mathrm{Se}(\mathrm{VI})$ to $\mathrm{Se}(\mathrm{O})$ took place under laboratory conditions using sediments taken from an agricultural drain-water evaporation pond in the San Joaquin Valley (Oremland and others, 1989). This 
same mechanism was presumed responsible (Oremland, 1994) for reduction of Se(VI) in surface soil samples (Sposito and others, 1991) and subsurface sediment samples (Dubrovsky and others, 1990) from the Panoche Creek alluvial fan and sediments from Kesterson National Wildlife Refuge (Masscheleyn and others, 1989; Long and others, 1990). Dissimilatory Se(VI) reduction was shown to occur in sediments from environments ranging from pristine, freshwater alpine lakes to alkaline hypersaline lakes (Steinberg and Oremland, 1990). Because nitrate inhibits Se(VI) reduction in anaerobic sediment slurries and soil incubations (Oremland and others, 1989), complete removal of nitrate was necessary prior to reduction of $\mathrm{Se}(\mathrm{VI})$ in enrichment cultures of Se(VI) reducers (Steinberg and others, 1992). In contrast, Macy (1994) reported a newly identified organism that anaerobically reduces $\mathrm{Se}(\mathrm{VI})$ in the presence of nitrate. Microbially mediated reduction of Se(VI) probably is responsible for the low concentrations of selenium observed in shallow ground water in the TLB subzone.

\section{Arsenic}

Shallow ground water concentrations of arsenic in the study area ranged from less than the detection limit of 1 to $2,600 \mu \mathrm{g} / \mathrm{L}$. The USEPA classifies arsenic as a priorty pollutant with an aquatic life criterion for chronic exposure to $\mathrm{As}$ (III) of 190 $\mu \mathrm{g} / \mathrm{L}$ and a proposed criterion of $48 \mu \mathrm{g} / \mathrm{L}$ for As(V) based on the lowest observable effect level (U.S. Environmental Protection Agency, 1986). The maximum contaminant level for arsenic in drinking water is $50 \mu \mathrm{g} / \mathrm{L}$ (U.S. Environmental Protection Agency, 1986), and a draft health advisory concentration of $2 \mu \mathrm{g} / \mathrm{L}$ has been proposed relative to cancer risk (U.S. Environmental Protection Agency, 1993). In this study, 27 samples exceeded the 50$\mu \mathrm{g} / \mathrm{L}$ drinking-water criterion and 91 samples exceeded the $2-\mu \mathrm{g} / \mathrm{L}$ health-advisory concentration. Thus, potential exists for elevated concentrations of arsenic to affect both aquatic life and human health, especially if ground water containing high concentrations of arsenic either migrates to or is already present in regional aquifers used as drinking-water sources.

Distribution of arsenic in shallow ground water indicates significantly higher concentrations in the BE, NEM, SWM, and TLB subzones compared to the other three subzones (table 4 and fig. 12). Although the primary sources of arsenic and sele- nium appear to originate from similar geologic sources in mountains defining the basin, the highest concentrations of arsenic in shallow ground water are not always associated with the highest concentrations of arsenic in soil, and the processes controlling arsenic concentrations in shallow ground water generally are more complex than those for selenium.

The primary sources of arsenic appear to be marine sedimentary rocks of the Coast Range, San Emigdio and Tehachapi Mountains, and probably the Miocene marine sedimentary rocks exposed in the Sierra Nevada that affect the Poso Creek drainage (R.R. Tidball, U.S. Geological Survey, written commun., 1986), the hypothesized source area also associated with selenium. The highest concentrations of arsenic in soils (Tidball and others, 1986) adjacent to or affected by these potential geologic source areas also indicate their role as arsenic sources.

Concentrations of soil arsenic $>8.5 \mathrm{mg} / \mathrm{kg}$ (90th percentile of concentrations) are in three areas: west of Lost Hills, at the southern most part of the basin, and in the area on the southern margins of the Tulare Lake bed in southwestern Tulare County and north-central Kern County (Tidball and others, 1986; Wilson and others, 1990). The area west of Lost Hills is in the same vicinity as the areas associated with elevated concentrations of soil selenium, adjacent to parts of the Temblor Range of the Coast Range where Eocene and Miocene marine sedimentary rocks are exposed. Areas in the southern part of the basin also are in the same vicinity as those shown for elevated selenium in soils and are associated with exposed Eocene and Miocene marine sedimentary rocks in the San Emigdio and Tehachapi Mountains. The areas on the southeastern margin of the basin, east and southeast of Bakersfield, and on the southern margin of the Tulare Lake bed (fig. 1) are probably affected by exposed Miocene marine sedimentary rocks in the Sierra Nevada foothills (California Division of Mines and Geology, 1969). The area near Bakersfield is adjacent to these formations, and the area on the Tulare Lake bed margin probably is affected by intermittent flow from Poso Creek, which originates near these formations. Areas with elevated concentrations of soil arsenic generally are not directly related to areas with elevated concentrations of arsenic in shallow ground water. In fact, the areas with soil-arsenic concentrations $>8.5$ $\mathrm{mg} / \mathrm{kg}$ do not encompass any of our sampling sites. High concentrations of soil arsenic indicate 


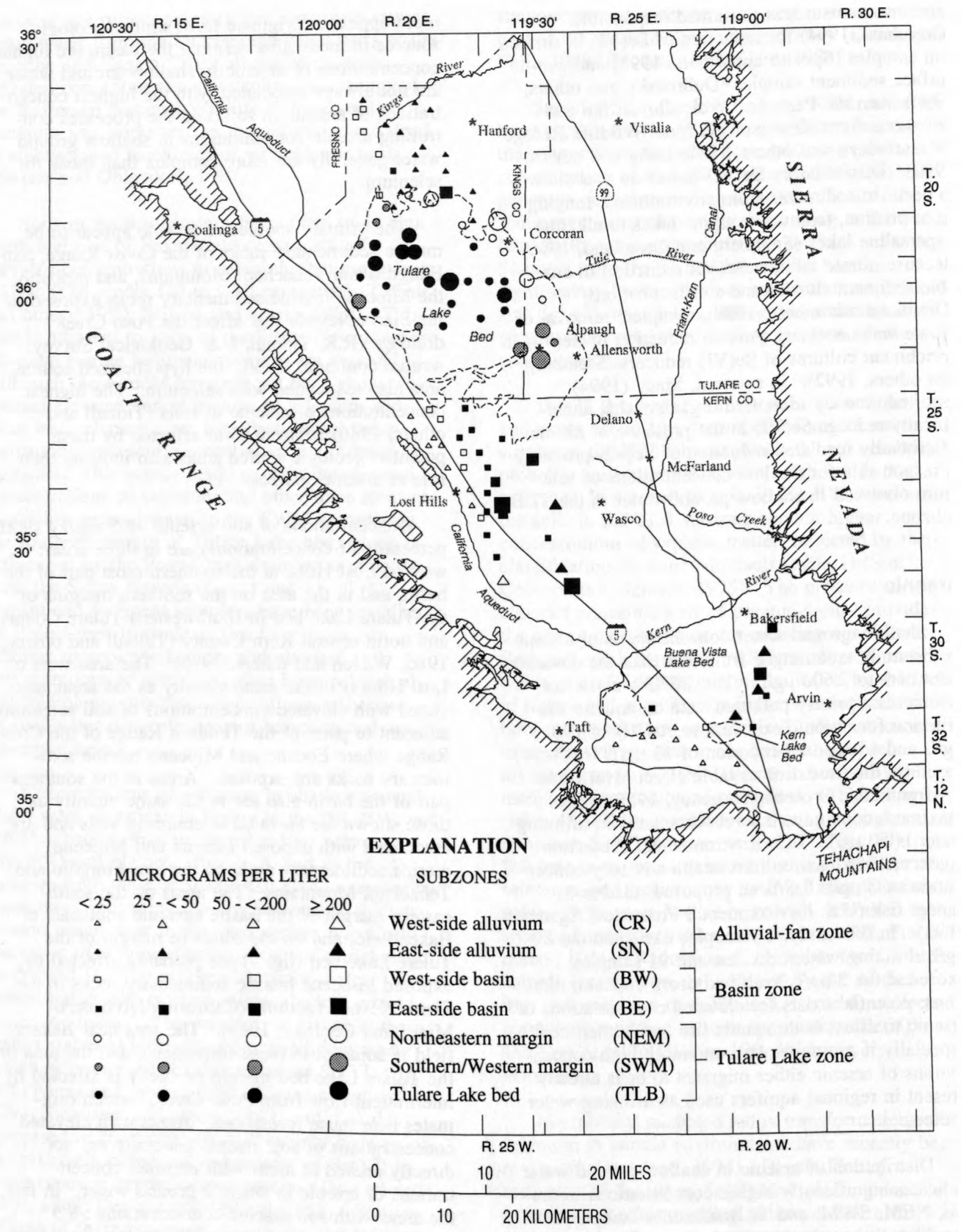

Figure 12. Distribution of arsenic for each zone and subzone, Tulare Basin, California. 
localized potential sources of arsenic, but other factors, such as the forms of arsenic in soils and sediments and biogeochemical and hydrologic processes, determine the distribution of arsenic in shallow ground water.

Redox and sorption processes appear to be dominant controls on arsenic solubility in shallow ground water in the study area. In general, As(V) predominates under oxidizing conditions and As(III) predominates under reducing conditions (fig. 10). Under extremely reducing conditions, insoluble $\mathrm{As}(0)$ can form. Organic forms of arsenic (mainly monomethylarsonate and dimethylarsinate) also have been reported in natural waters, and dimthylarsinate has been shown to predominate in a lake environment (Anderson and Bruland, 1991). Several drain-water sump samples from the study area were analyzed for arsenic species using the method of Glaubig and Goldberg (1988) and were found to contain $>90$ percent $\mathrm{As}(\mathrm{V})$ in samples containing total arsenic concentrations ranging from 63 to $811 \mu \mathrm{g} / \mathrm{L}$ (A.S. Maest, U.S. Geological Survey, written communication, 1989). Predominance of $\mathrm{As}(\mathrm{V})$ was anticipated because the samples were oxidized, as indicated by contact with atmospheric oxygen, the presence of nitrate, and relatively low concentrations of manganese

(California Department of Water Resources, written commun., 1993).

Ground water from a recently installed sampling site near Alpaugh, about $200 \mathrm{ft}$ from site 31D2 (fig. 1 ), was sampled from a cluster of four observation wells at depths ranging from about 10 to $200 \mathrm{ft}$ (10$\mathrm{ft}$ screened intervals) below land surface and was analyzed for arsenic species using methods similar to those of Glaubig and Goldberg (1988) and Masscheleyn and others (1991). Results of these analyses indicate that inorganic arsenic species were qualitatively distributed as expected: 96 percent of total arsenic $(295 \mu \mathrm{g} / \mathrm{L})$ present as $\mathrm{As}(\mathrm{V})$ under relatively oxidized conditions (Pt-electrode measured Eh of $290 \mathrm{mV}$ ) at about 10 to $20 \mathrm{ft}$ and 81 percent of total arsenic $(62 \mu \mathrm{g} / \mathrm{L})$ present as As(III) under reduced (Pt-electrode measured Eh of 107 $\mathrm{mV}$ ) and possibly methanogenic conditions at about 185 to $195 \mathrm{ft}$. No organic forms of arsenic were detected.

Adsorption of $\mathrm{As}(\mathrm{V})$ and $\mathrm{As}(\mathrm{III})$ generally is agreed to be a major process controlling arsenic solubility (Sakata, 1987; Wauchope and McDowell, 1984; Huang and Liaw, 1979; Fuller and others,
1993). Sediments sampled from 6 to about $100 \mathrm{ft}$ below land surface near site 31D2 near Alpaugh were extracted using a $0.1 \mathrm{M}$ potassium phosphate $\left(\mathrm{K}_{2} \mathrm{HPO}_{4}\right)$ solution adjusted to $\mathrm{pH} 8$ to estimate adsorbed arsenic, a method previously used to estimate adsorbed Se(IV) (Fujii and others, 1988; Fujii and Burau, 1989; Chao and Sanzalone, 1989). Results indicate that 10 to 39 percent of total arsenic in the sediments was phosphate extractable, indicating that adsorption probably is an important process controlling arsenic solubility.

Other processes also are affecting the solubility of arsenic in shallow ground water. Evaporation and concentration of arsenic in shallow ground water, similar to selenium, also is occurring. Under oxidized conditions, As(V) is strongly adsorbed by soil components such as iron oxides (Wauchope and Dowell, 1984; Sakata, 1987; Fuller and others, 1993), aluminum oxides (Masscheleyn and others, 1991), manganese oxides, clay edges, and organic matter (Welch and others, 1988) in contrast to $\mathrm{Se}(\mathrm{VI})$, which is not strongly adsorbed in these types of environments (Neal and Sposito, 1989; Fio and others, 1991). Adsorption of As(V) probably accounts for the lack of correlation between arsenic and salinity under oxidized conditions. Weathering of minerals containing arsenic and release to the ground water also is occurring under oxidizing conditions, but the relatively slow rates of weathering reactions, combined with adsorption of arsenic species, probably limit the importance of weathering reactions in controlling arsenic solubility in shallow ground water over periods as short as the development of irrigation in the study area.

The distribution of arsenic in shallow ground water also is affected by ground-water hydrology. Very little is currently known about the groundwater flow system throughout the study area, which emphasizes the need for future detailed studies of ground-water hydrology throughout the basin.

It is not possible to conclusively identify the processes controlling arsenic concentrations in shallow ground water in each of the subzones from the data collected in this study. Shallow groundwater concentrations of arsenic in the TLB subzone, as high as $230 \mu \mathrm{g} / \mathrm{L}$, probably reflect the predominance of the more soluble As(III) species. Reducing conditions favoring $\mathrm{As}$ (III) in this subzone are indicated by high concentrations of manganese and iron in shallow ground water (median concentrations of 7,950 and $4,000 \mu \mathrm{g} / \mathrm{L}$, 
respectively) and lack of nitrate, which had a median concentration of $<0.10 \mathrm{mg} / \mathrm{L}$ (as nitrogen) (table 4). High concentrations of arsenic in other subzones are not as easily explained.

Elevated concentrations of arsenic and selenium in saline, shallow ground water in the western United States generally do not exist together (Sylvester and others, 1988). Arsenate and Se(VI) should predominate under oxidized conditions. Adsorption of $\mathrm{As}(\mathrm{V})$ generally limits arsenic solubility, whereas $\mathrm{Se}(\mathrm{VI})$ is very soluble, especially in saline systems with high concentrations of sulfate. Conversely, under conditions reducing enough for As(III) to predominate, selenium is reduced to insoluble $\mathrm{Se}(0)$ (fig 10), and amorphous manganese and iron oxides are reduced and solubilized, removing significant adsorbents for $\mathrm{As}$ (III), further contributing to arsenic solubility.

Both arsenic and selenium concentrations are elevated, however, in several of the shallow groundwater samples collected during this study. For example, sites 31D2 and 4K1 near Alpaugh in the SWM subzone have arsenic concentrations of 160 and $230 \mu \mathrm{g} / \mathrm{L}$, respectively, and selenium concentrations of 1,000 and $350 \mu \mathrm{g} / \mathrm{L}$, respectively. Both samples are oxidized, as indicated by nitrate concentrations of 25 and $27 \mathrm{mg} / \mathrm{L}$ (as nitrogen), respectively, suggesting predominance of $\mathrm{As}(\mathrm{V})$ and $\mathrm{Se}$ (VI). Subsequent sampling and analysis of water from one of these wells verified that $\mathrm{As}(\mathrm{V})(90$ percent) and $\mathrm{Se}(\mathrm{VI})$ (98 percent) were the predominant species. These two samples also were evaporatively concentrated, as indicated by $\delta^{18} \mathrm{O}$ values of -2.0 and -4.6 permil.

As previously discussed, the elevated concentrations of selenium were anticipated, but the elevated concentrations of arsenic were not. Evaporation of shallow ground water increased salinity, and $\mathrm{Se}$ (VI) likely behaved conservatively and increased in proportion to salinity. In contrast, adsorption of $\mathrm{As}(\mathrm{V})$ probably affected arsenic solubility, and the partitioning relation between the solid and solution phases determined the groundwater concentration of arsenic. This relation is supported by the data from site 31D2 near Alpaugh (fig. 1), which indicates that large proportions of total sediment arsenic were phosphate extractable and that adsorption is a significant process controlling arsenic solubility. Under oxidizing conditions when $\mathrm{As}(\mathrm{V})$ predominates, adsorption still can be controlling arsenic solubility, but the abundance of adsorbed $\mathrm{As}(\mathrm{V})$ in the sediment-water system results in high concentrations in the shallow ground water.

One anomalously high arsenic concentration $(2,600 \mu \mathrm{g} / \mathrm{L})$ was detected in shallow ground water at site 33R2 in the NEM subzone (fig. 1). This site is on a railroad right-of-way, and the high arsenic concentration could be the result of an accidental spill or of long-term application of arseniccontaining herbicides for vegetation control. In the study area, application of arsenical herbicides and defoliants represents another potential source of arsenic.

\section{Uranium}

Shallow ground-water concentrations of uranium in the study area ranged from 1.1 to 5,400 $\mu \mathrm{g} / \mathrm{L}$ (table 4). A drinking-water maximum contaminant level of $20 \mu \mathrm{g} / \mathrm{L}$ was proposed in 1991 (U.S. Environmental Protection Agency, 1991) and has been published recently as a drinking-water standard (U.S. Environmental Protection Agency, 1993). This criterion was exceeded by 78 samples in this study.

The distribution of shallow ground-water uranium concentrations in the study area (table 4 and fig. 13) indicates that samples from the SWM subzone have significantly higher concentrations of uranium than do samples from the $\mathrm{CR}, \mathrm{SN}, \mathrm{BE}$, and TLB subzones, and concentrations in samples from the $\mathrm{CR}$ and $\mathrm{BW}$ subzones are significantly higher than those in samples from the TLB subzone. These results do not demonstrate any distinctive patterns relative to the location of source areas identified for other trace elements and probably are the result of uranium deposits in various locations in the basin and the geochemical processes affecting uranium solubility.

Uranium mining areas identified throughout California primarily are associated with the Sierra Nevada (Minobras, 1978). Granitic rocks generally contain elevated concentrations of uranium and are the primary source for sedimentary uranium deposits (Langmuir, 1978; Guthrie and Kleeman, 1986). Numerous uranium deposits within Kern County have been identified and are associated with the granitic Sierra Nevada on the east side of the basin and sedimentary shale deposits on the west 


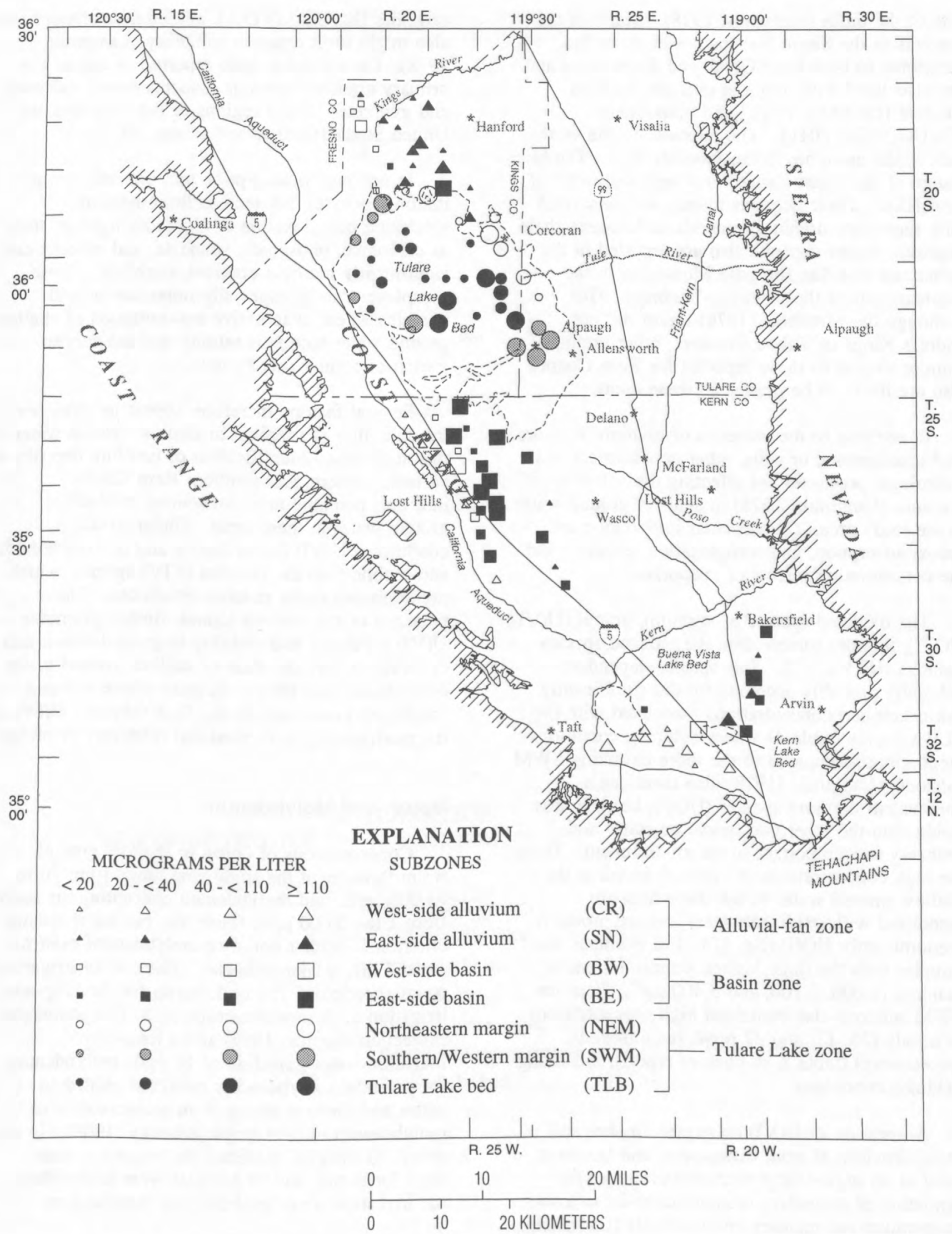

Figure 13. Distribution of uranium for each zone and subzone, Tulare Basin, California. 
side of the basin (Minobras, 1978). Many of the deposits in the Sierra Nevada are in areas that contribute to both Poso Creek and Kern River and are associated with uranium minerals such as autunite $\left[\mathrm{Ca}\left(\mathrm{UO}_{2}\right)_{2}\left(\mathrm{PO}_{4}\right)_{2}\right]$ and uranophane $\left[\mathrm{Ca}\left(\mathrm{UO}_{2}\right)_{2}\left(\mathrm{SiO}_{3} \mathrm{OH}\right)_{2}\right]$. The deposits on the west side of the basin are in the foothills of the Temblor Range of the Coast Range, west and southwest of Lost Hills. These deposits mainly are associated with secondary uranium minerals in Miocene shale deposits. Other deposits also are reported in the Tehachapi and San Emigdio Mountains in the southern part of the county (Minobras, 1978). Although the Minobras (1978) report did not address Kings or Tulare Counties, other uranium sources similar to those reported for Kern County also are likely to be present in these areas.

In addition to the presence of uranium in source rocks, sediments, or soils, other geochemical and hydrologic processes are affecting the solubility of uranium (Langmuir, 1978) in shallow ground water in the study area. Of particular importance are redox, adsorption, and complexation reactions and the concentrating effects of evaporation.

The oxidized species of uranium, uranyl [U(VI), $\left.\mathrm{UO}_{2}{ }^{2+}\right]$, is more soluble than the reduced species, uranous (U(IV), $\mathrm{U}^{4+}$ ). This species-dependent solubility probably accounts for the significantly lower uranium concentrations associated with the TLB subzone (table 4) where reducing conditions predominate compared to the more oxidizing SWM subzone. Langmuir (1978) also mentions a pentavalent uranium species $\left(\mathrm{UO}_{2}^{+}\right)$, but it is less stable than the other two oxidation states and probably is unimportant in the environment. Thus, the high concentrations of uranium found in the shallow ground water in the study area are associated with oxidized waters and are probably predominantly U(VI) (fig. 10). For example, the samples with the three highest concentrations of uranium $(3,000,3,100$, and $5,400 \mu \mathrm{g} / \mathrm{L})$ from the SWM subzone also contained high concentrations of nitrate $[25,17$, and $27 \mathrm{mg} / \mathrm{L}$ (as nitrogen), respectively] (table 8 , at back of report), indicating oxidized conditions.

Adsorption of $\mathrm{U}(\mathrm{VI})$ on organic matter and oxyhydroxides of iron, manganese, and titanium, cited as an important preconcentration step for formation of secondary uranium deposits in lowtemperature sedimentary environments (Langmuir, 1978), can exert considerable control on uranium solubility. Precipitation of U(VI) minerals such as carnotite $\left[\mathrm{K}_{2}\left(\mathrm{UO}_{2}\right)_{2}\left(\mathrm{VO}_{4}\right)_{2}\right]$, autunite, or uranophane also might limit uranium solubility (Langmuir, 1978). Carnotite has been reported as one of the primary uranium minerals associated with calcretes and gypcretes in arid regions of the southwestern United States (Carlisle and others, 1977).

In contrast to adsorption and mineral precipitation processes that tend to limit uranium solubility, complexation of U(VI) by ligands, such as carbonate, phosphate, vanadate, and silicate, can significantly increase uranium solubility. These complexes can be especially important in arid climates where evaporative concentration of shallon ground water increases salinity and the concentration of complexing ligands.

Several factors, therefore, appear to influence the solubility of uranium in shallow ground water ir the study area. Identification of uranium deposits is eastern, western, and southern Kern County indicates potential uranium sources to shallow ground water in these areas. Under oxidized conditions, U(VI) predominates and is more soluble and mobile than the reduced U(IV) species, which predominates under reduced conditions. The presence of complexing ligands further promotes U(VI) solubility and mobility in ground water, and evaporative concentration of shallow ground water can enhance this effect. In areas where reduced conditions exist, such as the TLB subzone, U(IV) is thermodynamically favored and relatively insoluble.

\section{Boron and Molybdenum}

Concentrations of boron in shallow ground water throughout the study area range from 70 to $73,000 \mu \mathrm{g} / \mathrm{L}$, and molybdenum concentrations range from 1 to $15,000 \mu \mathrm{g} / \mathrm{L}$ (table 4 ). No water-quality criterion for either boron or molybdenum exist for aquatic life or human health. There is an irrigation water criterion of $750 \mu \mathrm{g} / \mathrm{L}$ boron for the long-term irrigation of B-sensitive crops (U.S. Environmental Protection Agency, 1986) and a long-term irrigation-water guideline of $10 \mu \mathrm{g} / \mathrm{L}$ molybdenum for potential molybdenosis problems related to cattle and sheep resulting from accumulation of molybdenum in feed crops (Allaway, 1968). In this study, 93 samples exceeded the irrigation-water limit for boron, and 99 samples were higher than the irrigation-water guideline for molybdenum.

Significantly higher concentrations of boron and molybdenum in shallow ground water were found

38 Areal Distribution of Selected Trace Elements, Salinity, and Major Ions, Tulare Basin, Southern San Joaquin Valley, California 


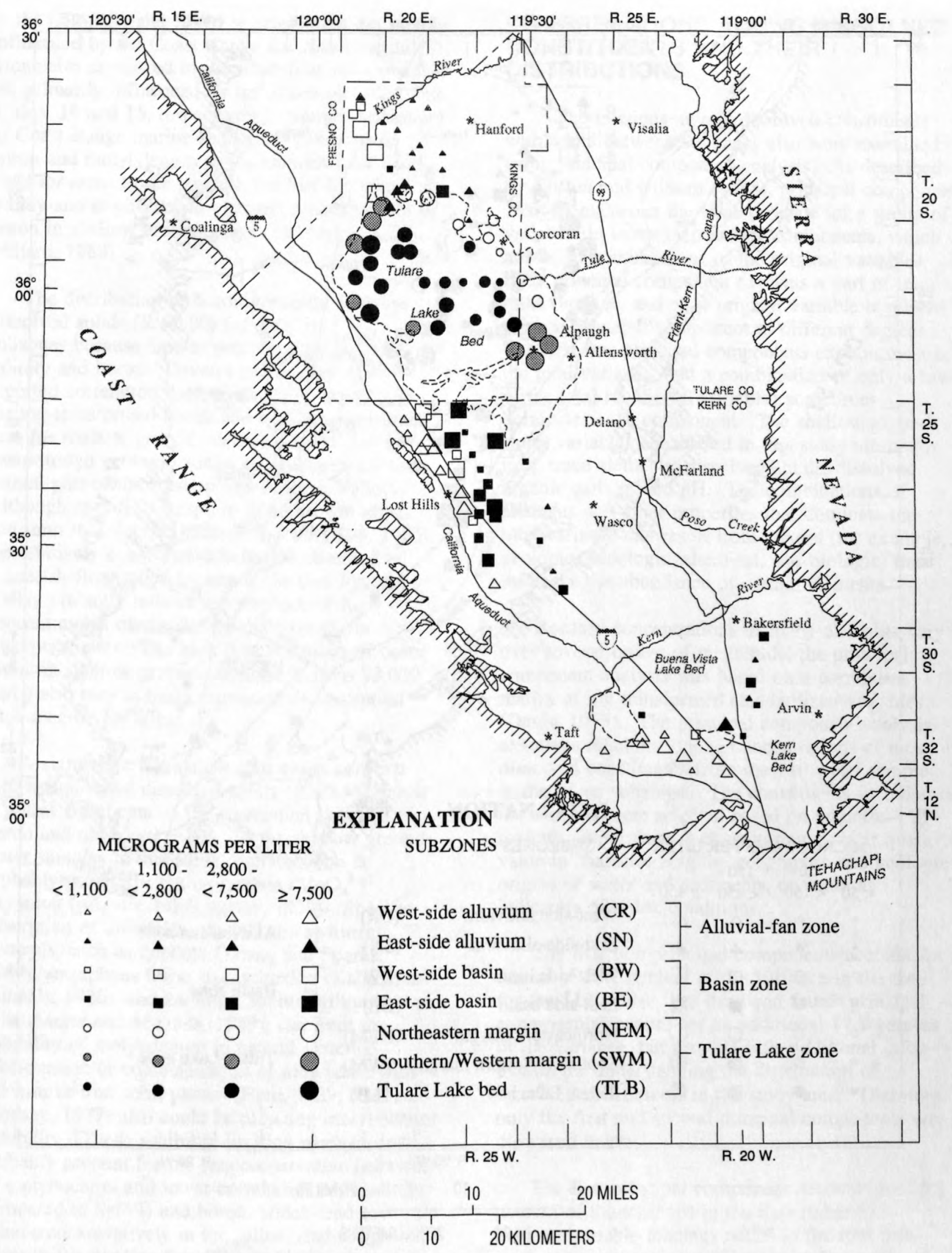

Figure 14. Distribution of boron for each zone and subzone, Tulare Basin, California. 


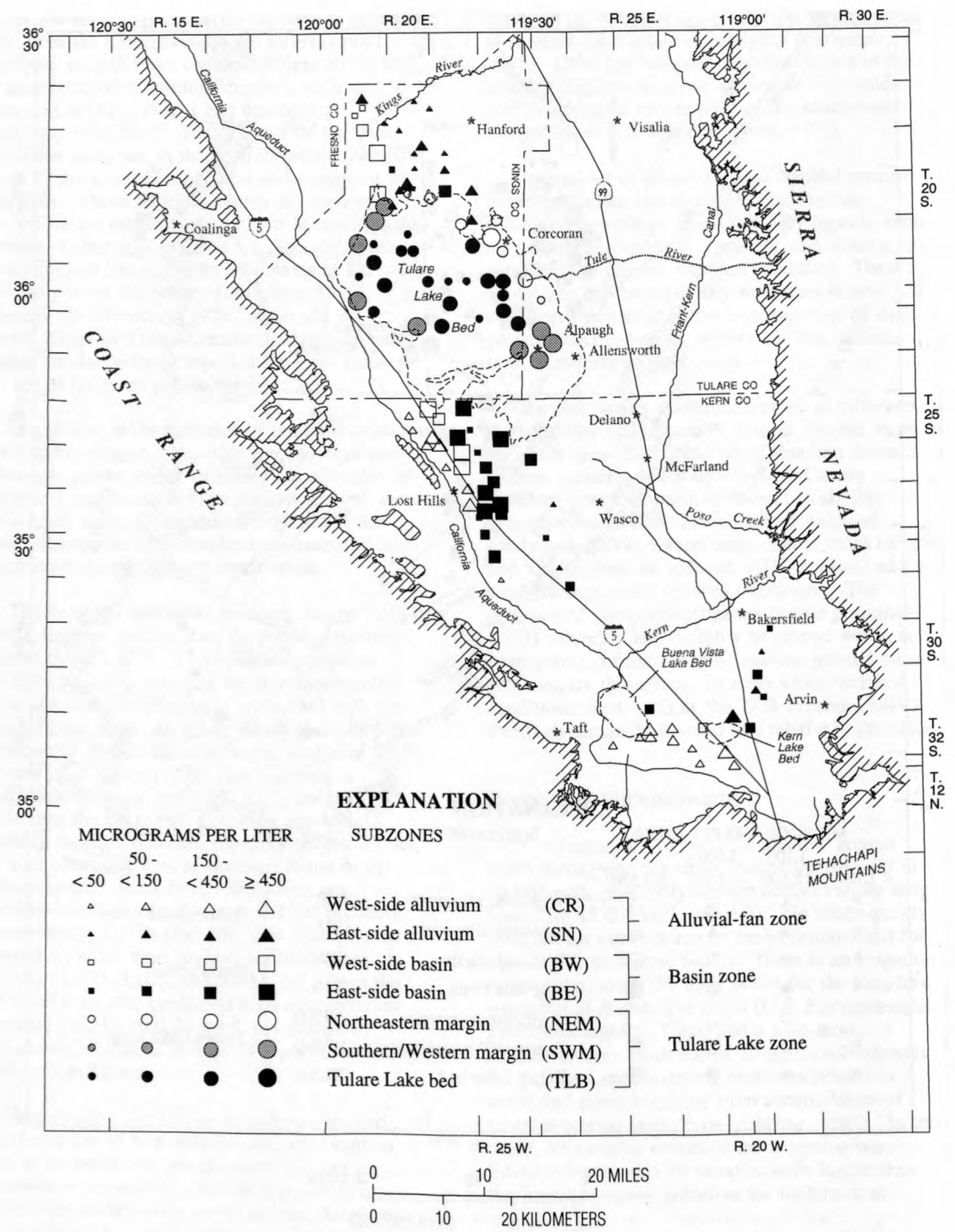

Figure 15. Distribution of molybdenum for each zone and subzone, Tulare Basin, California. 
in the CR, BW, and SWM subzones that are mainly influenced by the Coast Range and San Emigdio Mountains compared to the other four subzones that are primarily influenced by the Sierra Nevada (table 4; figs. 14 and 15, respectively). Similar influences of Coast Range marine-sedimentary sources on boron and molybdenum concentrations have been cited for areas to the north in the San Joaquin Valley and implicated in elevated concentrations of boron in shallow ground water (Deverel and Millard, 1988).

The distribution of boron generally follows dissolved solids $\left(\mathrm{R}^{2}=0.80\right)$ for data from all subzones because similar processes affect both salinity and boron. Deverel and Millard (1988) reported correlation coefficients of 0.90 and 0.93 for log-transformed boron and specific-conductance data for shallow ground water in alluvial-fan and basin-trough geologic zones, respectively, for the central part of the western San Joaquin Valley. Although specific adsorption of boron can affect and limit its solubility (Keren and Bingham, 1985), the relatively conservative behavior observed in saline, shallow ground water in the San Joaquin Valley probably reflects the presence of high concentrations of competing constituents for adsorption sites. The high concentrations of boron found in shallow ground water (as high as 73,000 $\mu \mathrm{g} / \mathrm{L}$ ) also may indicate saturation of adsorption sites specific for boron.

A significant correlation also exists between molybdenum and dissolved solids $\left(\mathrm{R}^{2}=0.44\right)$, but it is not as significant as the correlation between boron and dissolved solids. In the shallow groundwater samples in this study, molybdenum is probably present as the molybdate $\left(\mathrm{MoO}_{4}{ }^{2-}\right)$ oxyanion $\left(\mathrm{pK}_{2}=4.24\right)$ (Lindsay, 1979). Specific adsorption of molybdate on soil and sediment minerals, such as goethite (Zhang and Sparks, 1989), amorphous ferric oxyhydroxide (Kaback and Runnels, 1980), and kaolinite, montmorillonite, and illite (Motta and Miranda, 1989), can limit the solubility of molybdenum in natural systems. Precipitation or coprecipitation of molybdate with calcium or iron solid phases (Hem, 1989; Vlek and Lindsay, 1977) also could be affecting molybdenum solubility. These solubility-limiting mechanisms probably account for the less conservative behavior of molybdenum and lower correlation with salinity. compared to $\mathrm{Se}(\mathrm{VI})$ and boron, which tend to behave conservatively in the saline, shallow ground water in the western San Joaquin Valley (Deverel and Millard, 1988) and in the study area.

\section{INTERRELATIONS AMONG DISSOLVED CONSTITUENTS AND THEIR DISTRIBUTIONS}

The relations among dissolved constituents within and between subzones also were examined using principal component analysis. As described by Clifton and Gilliom (1988), principal component analysis expresses the total variance for a group of variables in terms of principal components, which are linear combinations of the original variables. Each principal component explains a part of the total variance, and each original variable is related to each principal component to different degrees. The first few principal components explain most of the total variance, and a combination of only a few of the total number of variables sometimes dominates each component. The shallow groundwater variables considered in this study are major ions, trace elements, dissolved solids, dissolved organic carbon, and $\mathrm{pH}$. The combinations of elements and other properties that dominate the total variance can result from factors (for example, geologic, pedologic, chemical, and biologic) that influence the abundance of certain elements.

Because concentrations of many elements vary over several orders of magnitude, the principal component analysis was based on a correlation matrix of log-transformed standardized variables (Davis, 1973). The principal component analysis examines relations among concentrations of most dissolved constituents from the 110 wells sampled in the seven subzones. The constituents included in the analysis were selected based on potential toxicity, importance in characterizing water quality, value in characterizing the geographic and geologic origins of water and sediments, or value as indicators of redox conditions.

The first two principal components account for a total of 50.7 percent of the variance in the data for the 110 wells. The third and fourth principal components account for an additional 17.7 percent of the variance, but provide little additional information for understanding the distribution of dissolved constituents in the study area. Therefore, only the first and second principal components are discussed below.

The first principal component accounts for 35.1 percent of the variance in the data (table 5). Positive variable loadings $>0.20$ in the first principal component are listed in descending order of dominance in table 5. Dissolved solids, major ions, 
Table 5. Correlation of constituents with the first two principal components for all three zones (110 samples), Tulare Basin, California

[Only variable loadings with absolute values $\geq 0.20$ are reported. Number in parentheses is percentage of total variance]

\begin{tabular}{|c|c|c|c|}
\hline \multicolumn{4}{|c|}{ Variable loadings } \\
\hline \multicolumn{2}{|c|}{ Principal component I (35.1) } & \multicolumn{2}{|c|}{ Principal component II (15.6) } \\
\hline Dissolved solids & 0.31 & $\mathrm{pH}$ & 0.38 \\
\hline Sulfate & .29 & Nitrate & .32 \\
\hline Sodium & .29 & Uranium & .30 \\
\hline Chloride & .29 & Vanadium & .27 \\
\hline Boron & .27 & Molybdenum & .23 \\
\hline Magnesium & .27 & Selenium & .20 \\
\hline Bromine & .26 & & \\
\hline Lithium & .25 & Manganese & -.29 \\
\hline Potassium & .22 & Nickel & -.28 \\
\hline Dissolved oxygen content & .22 & Iron & -.25 \\
\hline Calcium & .21 & & \\
\hline Molybdenum & .21 & & \\
\hline
\end{tabular}

and relatively conservative trace elements dominate the variables in this component. Most of these elements are related to salinity. Inclusion of dissolved organic carbon in this principal component probably reflects the unique depositional environment that results in the presence of elevated concentrations of both dissolved organic carbon and salinity in samples from the SWM and TLB subzones of the Tulare Lake zone.

The second principal component explains 15.6 percent of the variance in the data. Positive variable loadings $>0.20(\mathrm{pH}$, nitrate, uranium, vanadium, molybdenum, selenium) and negative variable loadings $<-0.20$ in this principal component also are listed in table 5. These variables generally reflect influences of redox conditions. Variables with positive loadings $>0.20$ are constituents with higher $\mathrm{pH}$ values or higher concentrations under oxidized conditions. In contrast, the solubilities of manganese and iron (negative variable loadings $<-0.20)$ are generally higher under reduced conditions.

Results of the principal component analysis of the 110 samples from the seven subzones generally support the interpretations discussed above. The first principal component is related to salinity and explains 35.1 percent of the variance in the data. The distribution and variability of salinity and constituents related to salinity are key factors in describing and interpreting the shallow groundwater quality in the basin. Another important influence on shallow ground-water quality that strongly affects trace-element distributions is relatec to redox and is reflected in the second principal component, which explains 15.6 percent of the variance in the data. Together, these two principal components represent two of the major influences on shallow ground-water quality determined during this study, salinity and redox.

\section{SUMMARY AND CONCLUSIONS}

High concentrations of selenium in shallow ground water in the Tulare Basin in the southern San Joaquin Valley, California, represent a source of selenium in irrigation drain water that may be disposed of in evaporation ponds. The study described here, undertaken because of concerns related to potential mortality and deformity of waterbirds as a result of exposure to elevated concentrations of selenium in evaporation ponds, assessed the distribution of salinity and selected trace elements in shallow ground water in the Tulare Basin. Results were interpreted in relation to surficial geology, sediment depositional environment, soil characteristics, and hydrologic processes.

One hundred and seventeen wells were sampled and analyzed in areas of the Tulare Basin where shallow ground water is within $20 \mathrm{ft}$ of land surface. The constituents of primary concern were selenium, arsenic, and salinity; uranium, boron, and 
molybdenum also were evaluated. Surficial geology, depositional environment, soil classification, and sediment sources were used to categorize 110 of the sampling sites into three zones and seven subzones [alluvial-fan zone: west-side alluvium (CR) subzone, east-side alluvium (SN) subzone; basin zone: west-side basin (BW) subzone, east-side basin (BE) subzone; Tulare Lake Zone: northeastern margin (NEM) subzone, southern/ western margin (SWM) subzone, Tulare Lake bed (TLB) subzone] and provided the framework for inter- preting shallow ground-water quality.

Salinity and major-ion composition of the shallow ground water for the alluvial-fan and basin zones are strongly influenced by the origin of sediments and stream-water quality. Samples from the CR and BW subzones are influenced primarily by the Coast Range and the San Emigdio and Tehachapi Mountains and generally are more saline and contain comparatively higher concentrations of sulfate than samples from the $\mathrm{SN}$ and BE subzones. The $\mathrm{SN}$ and $\mathrm{BE}$ subzones are influenced primarily by stream water and sediment originating from the Sierra Nevada. These differences reflect the predominance of saline, marine sedimentary formations in the Coast Range and the San Emigdio Mountains in contrast to the predominance of igneous and metamorphic formations in the Sierra Nevada and the Tehachapi Mountains.

Analysis of $\delta^{18} \mathrm{O}$ and $\delta \mathrm{D}$ data indicate that samples from the $\mathrm{CR}, \mathrm{BW}$, and $\mathrm{BE}$ subzones were affected most by evaporation, with the most isotopically enriched samples generally corresponding to the samples with the highest salinities. In contrast, samples from the SN subzone generally reflect isotopic signatures similar to that of the local ground water for the San Joaquin Valley.

In the Tulare Lake zone, samples from the SWM subzone had the highest salinities and generally had the most evaporated water compared to the NEM and TLB subzones. Tritium data also indicate that most of the samples from this subzone are older, pre-1952 water. Ground water in the SWM subzone is mainly affected by saline, marine sedimentary rocks in the Coast Range (west-side source), and probably by Poso Creek drainage originating in the Sierra Nevada (east-side source) where Miocene marine sedimentary rocks are uncharacteristically exposed. Evaporation of shallow ground water also has contributed to the high salinities as indicated by enrichment of ${ }^{18} \mathrm{O}$ and $\mathrm{D}$ caused by isotopic fractionation.
Samples from the NEM subzone had the lowest salinities in the Tulare Lake zone. Ground water in this subzone is influenced mainly by the Kings and Tule Rivers, reflecting the relative abundance of low-salinity water from the Sierra Nevada. The salinity of the TLB subzone samples is intermediate between those of the SWM and NEM subzones and reflects the mixture of Coast Range and Sierra Nevada sediments in this subzone and evaporative concentration. The $\delta^{18} \mathrm{O}$ and $\delta \mathrm{D}$ data for samples from the TLB subzone demonstrate evaporative effects on shallow ground water that also are reflected by the significantly higher salinities for this subzone compared to the NEM subzone.

The distribution of selenium in shallow ground water is influenced mainly by selenium sources, evaporation of shallow ground water, depositional environment, and redox conditions. Elevated concentrations of selenium in soils and sediments are related to Upper Cretaceous, Eocene, and Miocene marine sedimentary rocks originating in the Coast Range and San Emigdio and Tehachapi Mountains and probably to Miocene marine sedimentary rocks exposed in the Sierra Nevada that influence the Poso Creek drainage. Subzones affected by these sediment sources (CR, BW, SWM) generally contain elevated concentrations of selenium in sediments and shallow ground water. Delta ${ }^{18} \mathrm{O}$ and $\delta \mathrm{D}$ data indicate that evaporative concentration of shallow ground water has influenced the elevated salinity levels in these areas. The presence of nitrate in samples from these subzones suggests that selenium is present primarily as $\mathrm{Se}(\mathrm{VI})$, which tends to behave conservatively under these oxidized conditions. Evaporation also has contributed to the high concentrations of selenium in shallow ground water in these subzones.

Significantly lower concentrations of selenium in the SN, BE, and NEM subzones, compared to the other four subzones, reflect the influence of mainly Sierra Nevada sources of sediment and stream water low in selenium content. The low concentrations of selenium in the TLB subzone, which is affected by sediment sources from the Coast Range, are attributed to the predominance of reducing conditions in this subzone. Lack of nitrate and elevated concentrations of manganese and iron in samples from the TLB subzone indicate conditions reducing enough to transform selenium to $\operatorname{Se}(0)$.

Significantly higher concentrations of arsenic in shallow ground water were detected in the $\mathrm{BE}$, 
NEM, SWM, and TLB subzones compared to the other three subzones. The primary arsenic sources probably are similar to the sources for selenium--the marine sedimentary rocks in the Coast Range and San Emigdio Mountains and probably Miocene marine sedimentary rocks exposed in the Sierra Nevada and influencing the Poso Creek drainage. Elevated concentrations of arsenic in shallow ground water, however, are not necessarily associated with elevated soil concentrations. The distribution of arsenic in shallow ground water is influenced mainly by redox and sorption processes. In the TLB subzone where conditions are reducing enough to remove selenium from solution, elevated arsenic concentrations probably reflect predominance of the more soluble As(III) species. In contrast, $\mathrm{As}(\mathrm{V})$ predominates under oxidizing conditions (for example, in the SWM subzone), and sorption of $\mathrm{As}(\mathrm{V})$ appears to be controlling arsenic solubility; the abundance of arsenic in the system causes elevated shallow ground-water concentrations of arsenic under these oxidized conditions.

Elevated concentrations of uranium (as high as $5,400 \mu \mathrm{g} / \mathrm{L}$ ) were detected in shallow ground water in the study area, with the highest concentrations in the SWM subzone. Elevated uranium probably is associated with uranium deposits documented at various locations in Kern County and possibly present other areas in the basin. The U(VI) species predominates under oxidizing conditions and is more soluble and mobile than the reduced U(IV) species. This species-dependent solubility probably accounts for the high concentrations of uranium in the oxidized SWM subzone and the low uranium concentrations in the reduced TLB subzone. In addition to redox, other processes, such as adsorption of U(VI) on mineral and organic-matter surfaces and precipitation of uranium minerals, tend to limit uranium solubility, whereas complexation of U(VI) by ligands, such as carbonate, phosphate, and silicate, can significantly increase uranium solubility.

Significantly higher concentrations of boron and molybdenum in shallow ground water were detected in the CR, BW, and SWM subzones compared with the other four subzones. These results probably reflect the influence of the marine sedimentary rocks cited above as the probable sources for selenium and arsenic. Boron behaves conservatively in shallow ground water in the study area as indicated by its high correlation with salinity $\left(\mathrm{R}^{2}=0.80\right)$. The relation between molybdenum and salinity
$\left(\mathrm{R}^{2}=0.44\right)$ is less significant compared to boron. Other processes, such as adsorption and precipitation of molybdenum, probably limit molybdenum solubility and account for its less conservative behavior.

Principal component analysis of data for samples from the seven subzones indicated that 50.7 percent of the variance in the data are explained by the first two principal components. The first principal component accounted for 35.1 percent of the variance and is related to salinity. The second component explained 15.6 percent of the variance and is related to redox. These principal components reflect the two major influences on shallow groundwater quality in this study: salinity and redox.

\section{References Cited}

Allaway, W.H., 1968, Agronomic controls over the environmental cycling of trace elements: Advances in Agronomy, v. 20, p. 235-274.

Anderson, L.C.D., and Bruland, K.W., 1991, Biogeochemistry of arsenic in natural waters: The importance of methylated species: Environmental Science and Technology, v. 25, p. 420-427.

Arrouse, K.D., and Anderson, C.H., 1986, Soil Survey of Kings County, California: U.S. Department of Agriculture, Soil Conservation Service, 1 case (1 v., 28 maps).

Bohn, H.L., McNeal, B.L., and O'Connor, G.A., 1979, Soil chemistry: New York, John Wiley, 329 p.

California Department of Water Resources, 1985, Selenium concentrations discovered during monitoring of shallow perched ground water in Kern County: Fresno, California, San Joaquin District Memorandum, July $31,1985,6 \mathrm{p}$.

California Department of Water Resources, 1986, San Joaquin Valley Drainage Monitoring Program, 1985: Fresno, California, San Joaquin District Report, 55 p. 1987, Present and potential drainage problem areas, San Joaquin Valley: Fresno, California, San Joaquin District, 1 sheet.

California Department of Water Resources, 1992, State Water Project Water Quality 1989-1991: Sacramento, California, Department of Water Resources, $121 \mathrm{p}$.

California Division of Mines and Geology, 1959a, Geologic map of California, San Luis Obispo sheet: California Department of Conservation, 2 sheets.

1959b, Geologic map of California, Santa Cruz sheet: California Department of Conservation, 2 sheets.

1965, Geologic map of California, Bakersfield sheet: California Department of Conservation, 2 sheets. 
California Department of Mines and Geology, 1966a, Geologic map of California, Fresno sheet: California Department of Conservation, 2 sheets.

1966b, Geologic map of California, San Jose sheet: California Department of Conservation, 2 sheets. 1969, Geologic map of California: San Francisco, various pagination.

California Regional Water Quality Control Board, Central Valley Region, 1988, Water and sediment quality in evaporation basins used for the disposal of agricultural subsurface drainage water in the San Joaquin Valley, California: Sacramento, $50 \mathrm{p}$.

Carlisle, D., Merifield, P., Orme, A., and Lunt, O.R., 1977, The distribution of calcretes and gypcretes in southwestern United States and their uranium favorability: U.S. Energy Resources Development Administration, subcontract 76-022-E, Midyear Progress Report, June-December 1976.

Chao, T.T., and Sanzalone, R.F., 1989, Fractionation of soil selenium by sequential partial dissolution: Soil Science Society of America Journal, v. 53, p. 385-392.

Clifton, D.G., and Gilliom, R.J., 1988, Trace elements in bed sediments of the San Joaquin River and its tributary streams, California, 1985: U.S. Geological Survey Water-Resources Investigations Report 88-4169, $33 \mathrm{p}$.

Conover, W.J., 1980, Practical nonparametric statistics (2d ed.): New York, John Wiley, 493 p.

Coplen, T.B., Kendall, Carol, and Davis, G.H., 1985, Oxygen and hydrogen stable isotope measurements of ground waters for the central west side of the San Joaquin Valley, California: U.S. Geological Survey Open-File Report 85-490, 21 p.

Cowan, C.E., 1988, Review of selenium thermodynamic data: Electric Power Research Institute, Report EA5655, Palo Alto, California

Craig, H., 1961, Isotopic variations in meteoric waters: Science, v. 133, p. 1702-1703.

Crecelius, E.A., Bloom, N.S., Cowan, C.E., and Jenne, E.A., 1986, Speciation of selenium and arsenic in natural waters and sediments. Volume 2: Arsenic speciation: Palo Alto, California, Electric Power Research Institute, Final Report, EPRI EA-4641, Research Project 2020-2.

Croft, M.G., 1972, Subsurface geology of the late Tertiary and Quaternary water-bearing deposits of the San Joaquin Valley, California: U.S. Geological Survey Water-Supply Paper 1999-H, 29 p.

Davis, G.H., 1961, Geologic control of mineral composition of stream waters of the eastern slope of the southern Coast Range, California: U.S. Geological Survey Water-Supply Paper 1535-B, $30 \mathrm{p}$.

Davis, G.H., and Coplen, T.B., 1989, Late Cenozoic paleohydrology of the western San Joaquin Valley, California, as related to structural movements in the central Coast Range: Boulder, Colorado, Geological Society of America Special Paper 234, $40 \mathrm{p}$.
Davis, G.H., Green, J.H., Olmstead, F.H., and Brown, D.W., 1959, Ground-water conditions and storage capacity in the San Joaquin Valley, California: U.S. Geological Survey Water-Supply Paper 1469, 287 p.

Davis, J.C., 1973, Statistics and data analysis in geology: New York, John Wiley, $550 \mathrm{p}$.

Deverel, S.J., Gilliom, R.J., Fujii, Roger, Izbicki, J.A., and Fields, J.C., 1984, Areal distribution of selenium and other inorganic constituents in shallow ground water of the San Luis Drain Service Area, San Joaquin Valley, California: A preliminary study: U.S. Geological Survey Water-Resources Investigations Report 84-4319, 67 p.

Deverel, S.J., and Fujii, Roger, 1988, Processes affecting the distribution of selenium in shallow groundwater of agricultural areas, western San Joaquin Valley, California: Water Resources Research, v. 24, no. 4, p. $516-524$.,

1990, Chemistry of trace elements in soils and ground water, in Tanji, K.K., ed., Agricultural salinity assessment and management: New York, American Society of Civil Engineers, ASCE Manuals and Reports on Engineering Practice no. 71, p. 64-90.

Deverel, S.J., and Millard, S.P., 1988, Distribution and mobility of selenium and other trace elements in shallow groundwater of the western San Joaquin Valley, California: Environmental Science and Technology, v. 22 , no. 6 , p. 697-702.

Dubrovsky, N.M., Neil, J.M., Fujii, Roger, Oremland, R.S., and Hollibaugh, J.T., 1990, Influence of redox potential on selenium distribution in ground water, Mendota, western San Joaquin Valley, California: U.S. Geological Survey Open-File Report 90-138, 24 p.

Dubrovsky, N.M., Neil, J.M., Welker, M.C., and Evenson, K.D., 1991, Geochemical relations and distribution of selected trace elements in ground water of the northern part of the western San Joaquin Valley, California: U.S. Geological Survey WaterSupply Paper 2380, $51 \mathrm{p}$.

Fio, J.L., Fujii, Roger, and Deverel, S.J., 1991, Selenium mobility and distribution in irrigated and nonirrigated alluvial soils: Soil Science Society of America Journal, v. 55, no. 5, p. 1313-1320.

Fishman, M.J. and Friedman, L.C., eds., 1989, Methods for determination of inorganic substances in water and fluvial sediments: Techniques of WaterResources Investigations of the United States Geological Survey, Book 5, Chapt. A1, 585 p.

Fujii, Roger, 1988, Water-quality and sediment-chemistry data of drain water and evaporation ponds from Tulare Lake Drainage District, Kings County, California, March 1995 to March 1996: U.S. Geological Survey Open-File Report 87-700, 19 p.

Fujii, Roger, and Burau, R.G., 1989, Estimate of adsorbed Se(IV) in soils, western San Joaquin Valley, California [abs.]: Agronomy Abstracts, 81st Annual Meeting, American Society of of Agronomy, Las Vegas, Nevada, October 15-20, Madison, Wisconsin, p. 200. 
Fujii, Roger, Deverel, S.J., and Hatfield, D.B., 1988, Distribution of selenium in soils of agricultural fields, western San Joaquin Valley, California: Soil Science Society of America Journal, v. 52, no. 5, p. 12741283.

Fuller, C.C., Davis, J.A., Waychunas, G.A., and Rea, B.A., 1993, Surface chemistry of ferrihydrite: 2 . Kinetics of arsenate adsorption and coprecipitation: Geochimica et Cosmochimica Acta, v. 57, no. 10, p. 2271-2282.

Glaubig, R.A., and Goldberg, S., 1988, Determination of inorganic arsenic(III) and arsenic(III plus V) using automated hydride-generation atomic absorption spectrometry: Soil Science Society of America Journal, v. 52, p. 536-537.

Guthrie, V.A., and Kleeman, J.D., 1986, Changing uranium distributions during weathering of granite: Chemical Geology, v. 54, p. 113-126.

Hem, J.D., 1989, Study and interpretation of the chemical characteristics of natural water: U.S. Geological Survey Water-Supply Paper 2254, $263 \mathrm{p}$.

Huang, P.M., and Liaw, W.K., 1979, Adsorption of arsenite by lake sediments: International Revue Gesamten Hydrobiology, v. 64, no. 2, p. 263-271.

International Atomic Energy Agency, 1981, Statistical treatment of environmental isotope data in precipitation: Vienna, International Atomic Energy Agency Technical Report Series, no. 206.

Jones, B.E., 1987, Quality control manual of the U.S. Geological Survey's National Water Quality Laboratory: U.S. Geological Survey Open-File Report 87-457, 17 p.

Kaback, D.S., and Runnels, D.D., 1980, Geochemistry of molybdenum in some stream sediments and waters: Geochimica et Cosmochimica Acta, v. 44, p. 447456.

Keren, R., and Bingham, F.T., 1985, Boron in water, soils, and plants, in Stewart, B.A., ed., Advances in soil science: New York, Springer-Verlag, v. 1, p. 229-276.

Langmuir, Donald, 1978, Uranium solution-mineral equilibria at low temperatures with applications to sedimentary ore deposits: Geochimica et Cosmochimica Acta, v. 42 , no. 6, p. 547-569.

Lindsay, W.L., 1979, Chemical equilibria in soils: New York, Wiley-Interscience, $449 \mathrm{p}$.

Long, R.H.B., Benson, S.M., Tokunaga, T.K., and Yee, A., 1990, Selenium immobilization in a pond sediment at Kesterson Reservoir: Journal of Environmental Quality, v. 19, p. 302-311.

Macy, J.M., 1994, Biochemistry of selenium metabolism by Thauera selenatis gen.nov.sp nov. and use of the organism for bioremediation of selenium oxyanions in San Joaquin Valley drainage water, in Frankenberger, W.T., and Benson, S.M., eds., Selenium in the environment: New York, Marcel Dekker, p. 421-444.
Masscheleyn, P.H., Delaune, R.D., and Patrick, W.H., Jr., 1989, Transformations of selenium as affected by sediment oxidation-reduction potential and $\mathrm{pH}$ :

Environmental Science and Technology, v. 24, no. 1, p. 91-96.

Masscheleyn, P.H., Delaune, R.D., and Patrick, W.H., Jr., 1991, A hydride generation atomic absorption technique for arsenic speciation: Journal of Environmental Quality, v. 20, p. 96-100.

Mendenhall, W.C., Dole, R.B., and Stabler, Herman, 1916, Ground water in the San Joaquin Valley, California: U.S. Geological Survey Water-Supply Paper 398, $310 \mathrm{p}$.

Michel, R.L., 1989, Tritium deposition in the continental United States, 1953-83: U.S. Geological Suvey Water-Resources Investigations Report 89-4072, 46 p.

Minobras, 1978, Uranium deposits of ArizonaCalifornia-Nevada: Dana Point, California, 125 p.

Motta, M.M., and Miranda, C.F., 1989, Molybdate adsorption on kaolinite, montmorillonite, and illite: Constant capacitance modeling: Soil Science Society of America Journal, v. 53, p. 380-385.

Neal, R.H., and Sposito, Garrison., 1989, Selenate adsorption on alluvial soils: Soil Science Society of America Journal, v. 53, p. 70-74.

Neal, R.H., Sposito, Garrison, Holtzclaw, K.M., and Traina, S.J., 1987, Selenite adsorption on alluvial soils: I. Soil composition and $\mathrm{pH}$ effects: Soil Science Society of America Journal, v. 51, p. 1161-1165.

Norris, R.M., and Webb, R.W., 1990, Geology of California: New York, John Wiley, 541 p.

Ohlendorf, H.M., Hothem, R.L., Bunck, C.M., Aldrich, T.W., and Moore, J.F., 1986, Relationships between selenium concentrations and avian reproduction: Reno, Nevada, Transactions, North American Wildlife and Natural Resources Conference, 51st, p. 330-442.

Oremland, R.S., 1994, Biogeochemical transformations of selenium in anoxic environments, in Frankenberger, W.T., and Benson, S.M., eds., Selenium in the environment: New York, Marcel Dekker.

Oremland, R.S., Hollibaugh, J.T., Maest, A.S., Presser, T.S., Miller, L., and Culbertson, C., 1989, Selenate reduction to elemental selenium by anaerobic bacteria in sediments and culture: Biogeochemical significance of a novel, sulfate-independent respiration: Applied Environmental Microbiology, v. 55, p. 2333-2343.

Page, R.W., 1986, Geology of the fresh ground-water basin of the Central Valley, California, with texture maps and sections: U.S. Geological Survey Professional Paper 1401-C, 54 p.

Piper, D.Z, and Isaacs, C.M., in press, Minor element sources in the Monterey Formation, California: Seawater chemistry of deposition: U.S. Geological Survey Professional Paper 1566. 
Plummer, L.N., Michel, R.L., Thurman, E.M., and Glynn, P.D., 1993, Environmental tracers for age dating young ground water, in Alley, W.M., ed., Regional ground water quality: New York, Van Nostrand Rheinhold, p. 255-294.

Presser, T.S., and Barnes, Ivan, 1984, Selenium concentrations in waters tributary to and in the vicinity of the Kesterson National Wildlife Refuge, Fresno and Merced Counties, California; U.S. Geological Survey Water- Resources Investigations Report 84-4122, 26 p.

Presser, T.S. and Ohlendorf, H.M., 1987, Biogeochemical cycling of selenium in the San Joaquin Valley, California: Environmental Management, v. 11, p. 805-821.

Presser, T.S., and Swain, W.C., 1990, Geochemical evidence for Se mobilization by the weathering of pyritic shale, San Joaquin Valley, California, U.S.A.: Applied Geochemistry, v. 5, p. 703-717.

Presser, T.S., Swain, W.C., Tidball, R.R., and Severson, R.C., 1990, Geologic sources, mobilization, and transport of selenium from the California Coast Range to the western San Joaquin Valley: A reconnaissance study: U.S. Geological Survey Water-Resources Investigations Report 90-4070, 66 p.

Preston, W.L., 1981, Vanishing landscapes: Berkeley, University of California Press, 268 p.

Reddy, K.R., and Patrick, W.H., Jr., 1983, Effect of aeration on reactivity and mobility of soil constituents, in Nelson, D.W., Elrick, D.E., and Tanji, K.K., eds., Chemical mobility and reactivity in soil systems: Madison, Wisconsin, Soil Science Society of America Special Publication no. 11, p. 11-33.

Sakata, M., 1987, Relationship between adsorption of $\mathrm{As}(\mathrm{III})$ and boron by soil properties: Environmental Science and Technology, v. 27, no. 11, p. 1126-1130.

Schroeder, R.A., Palawaski, D.U., and Skorupa, J.P., 1988, Reconnaissance investigation of water quality, bottom sediment, and biota associated with irrigation drainage in the Tulare Lake bed area, southern San Joaquin Valley, California, 1986-87: U.S. Geological Survey Water-Resources Investigations Report 88-4001, $86 \mathrm{p}$.

Scott, M.J., and Morgan, J.J., 1990, Energetics and conservative properties of redox systems, in Melchior, D.C., and Bassett, R.L., Chemical modeling of aqueous systems II: Washington, D.C., American Chemical Society, ACS Symposium Series 416, p. 368-378.

Skorupa, J.P., and Ohlendorf, H.M., 1989, Drain water contaminants in eggs related to deformities in Tulare Basin water birds: U.S. Fish and Wildlife Service Research Information Bulletin 89-04, 2 p.

Soil Conservation Service, 1975, Soil taxonomy: A basic system of soil classification for making and interpreting soil surveys: Soil Conservation Service, U.S. Department of Agriculture, Agricultural Handbook no. 436, 754 p.
Sposito, G., Yang, A., Neal, R.H., and Mackzum, A., 1991, Selenate reduction in alluvial soil: Soil Science Society of America Journal, v. 55, p. 1597 1602.

Steinberg, N.A., and Oremland, R.S., 1990, Dissimilatory selenate reduction potentials in a diversity of sediment types: Applied Environmental Microbiology, v. 56, p. 3550-3557.

Steinberg, N.A., Switzer Blum, J., Hochstein, L., and Oremland, R.S., 1992, Nitrate is a preferred electron acceptor for growth of freshwater selenate-respiring bacteria: Applied Environmental Microbiology, v. 58, p. 426-428.

Strumm, Werner, and Morgan, J.J., 1981, Aquatic chemistry: New York, John Wiley, 780 p.

Sylvester, M.A., Deason, J.P., Feltz, H.R., and Engberg, R.A., 1988, Preliminary results of the Department of the Interior's irrigation and drainage studies: Planning now for irrigation and drainage: Lincoln, Nebraska, Irrigation and Drainage Division, American Society of Civil Engineers, [Proceedings], p. 665-667.

Thatcher, L.L., 1962, The distribution of tritium fallout in precipitation over North America: Bulletin of the International Association of Scientific Hydrology, v. 7 , no. 2 , p. $48-58$.

Tidball, R.R., Grundy, W.D., and Sawatzky, K.L., 1986, Kriging techniques applied to element distribution in soils of the San Joaquin Valley, California, in HAZTECH INTERNATIONAL, Hazardous Materials Management Exhibition and Conference, August 13-15, 1986, Denver, Colorado, Proceedings: Pollution Engineering Magazine, Chicago, Illinois, p. 992-1009.

Tidball, R.R., Severson, R.C., McNeal, J.M., and Wilson, S.A., 1990, A potential source area for selenium and mercury in agricultural drainage water at Kesterson Reservoir, San Joaquin Valley, California, in Doe, B.R., ed., Proceedings of a U.S. Geological Survey Workshop on Environmental Geochemistry: U.S. Geological Survey Circular 1033, p. 125-131.

U.S. Environmental Protection Agency, 1986, Quality criteria for water: U.S. Environmental Protection Agency 440/5-86-001, May 1986, 453 p.

1987, Ambient water quality criteria for selenium-1987: Washington, D.C., U.S.

Environmental Protection Agency 440/5-87-006. 1988, Water quality criteria documents: Federal Register, v. 53, no. 2, p. 177-179.

1991, National primary drinking water regulations; radionuclides; proposed rule: Federal Register, v. 56, no. 138 , July 18,1991 , p. 33051.

1993, Drinking water regulations and health advisories: Washington, D.C., U.S. Environmental Protection Agency, May 1993, 11 p.

U.S. Geological Survey, 1980, Ground water, Chapter 2 of National handbook of recommended methods for water-data aquisition: U.S. Geological Survey, Office of Water-Data Coordination, p. 2-1 to 2-149. 
Vlek, P.L.G., and Lindsay, W.L., 1977, Thermodynamic stability and solubility of molybdenum minerals in soils: Soil Science Society of America Journal, v. 41, p. 42-46.

Wauchope, R.D., and McDowell, L.L., 1984, Adsorption of phosphate, arsenate, methanearsonate, and cacodylate by lake and stream sediments:

Comparisons with soils: Journal of Environmental Quality, v. 13, no. 3, p.499-504.

Welch, A.H., Lico, M.S., and Hughes, J.L., 1988, Arsenic in groundwater of the western United States: Groundwater, v. 26, p. 333-347.

Weres, Oleh, Joauni, Abdur-Rahim, and Tsoa, Leon, 1989, The distribution, speciation, and geochemical cycling of selenium in a sedimentary environment, Kesterson Reservoir, California, U.S.A.: Applied Geochemistry, v. 4, p. 543- 563.
White, A.F., Benson, S.M., Yee, A.W., Wollenberg, H.A., Jr., and Flexser, Steven, 1991, Groundwater contamination at the Kesterson Reservoir, California 2.: Geochemical parameters influencing selenium mobility: Water Resources Research, v. 27, no. 6, p. 1085-1098.

Wilson, S.A., Kennedy, K.R., Gent, C.A., Briggs, P.H., Tidball, R.R., and McNeal, J.M., 1990, Analysis of soil samples from the San Joaquin Valley of California: U.S. Geological Survey Open-File Report 90-214, 56 p.

Wood, P.R., and Davis, G.H., 1959, Ground-water conditions in the Avenal- McKittrick Area, Kings and Kern Counties, California: U.S. Geological Survey Water Supply Paper 1457, $141 \mathrm{p}$.

Zhang, P.C., and Sparks, D.L., 1989, Kinetics and mechanisms of molybdate adsorption/desorption at the goethite/water interface using pressure-jump relaxation: Soil Science Society of America Journal, v. 53 , p. $1028-1034$. 
Table 6. Location, characteristics, and field measurements of sampled wells, Tulare Basin, California

[State well No.: See well-numbering system on page VI. Station no.: Unique number for each site based on latitude and longitude of the site. First six digits are latitude, next seven digits are longitude, and final two digits are a sequence number to uniquely identify each site. Water level and depth of well in feet below land surface. Altitude of land surface in feet above sea level. Temperature in degrees Celsius; barometric pressure in millimeters of mercury; --, no data]

\begin{tabular}{|c|c|c|c|c|c|c|c|c|c|c|}
\hline \multicolumn{2}{|c|}{ State well No. } & Station No. & Data & Time & $\begin{array}{l}\text { Water } \\
\text { level }\end{array}$ & $\begin{array}{c}\text { Depth } \\
\text { of } \\
\text { well }\end{array}$ & $\begin{array}{l}\text { Altitude } \\
\text { of land } \\
\text { surface }\end{array}$ & $\begin{array}{l}\text { Temper- } \\
\text { ature, } \\
\text { air }\end{array}$ & $\begin{array}{l}\text { Temper- } \\
\text { ature, } \\
\text { water }\end{array}$ & $\begin{array}{l}\text { Baro- } \\
\text { metric } \\
\text { pres- } \\
\text { sure }\end{array}$ \\
\hline \multicolumn{11}{|c|}{ Alluvium-fan zone -- West-side alluvium (CR) subzone } \\
\hline \multirow{2}{*}{$25 \mathrm{~S} / 20 \mathrm{E}-$} & $15 \mathrm{~A} 4 \mathrm{M}$ & 354536119474401 & $7-12-89$ & 1630 & 2.80 & 23.70 & 260 & 35.5 & 25.0 & 760 \\
\hline & 23P1M & 354355119471501 & $6-21-89$ & 1900 & 4.10 & 15.40 & 285 & 32.0 & 24.0 & 750 \\
\hline \multirow[t]{3}{*}{$25 \mathrm{~S} / 21 \mathrm{E}-$} & 29N1M & 354305119442901 & $6-21-89$ & 1715 & 3.49 & 15.00 & 232 & -- & 23.0 & 755 \\
\hline & 31P1M & 354211119451501 & $6-21-89$ & 1330 & 6.53 & 16.68 & 254 & 34.0 & 22.0 & 750 \\
\hline & 33N1M & 354212119432501 & $6-21-89$ & 1030 & 6.01 & 18.80 & 224 & 29.0 & 21.0 & 755 \\
\hline \multirow[t]{2}{*}{$26 \mathrm{~S} / 21 \mathrm{E}-$} & $16 \mathrm{R} 1 \mathrm{M}$ & 353935119423301 & $7-11-89$ & 1300 & 16.14 & 23.50 & 286 & 33.0 & 26.0 & 755 \\
\hline & 36Q1M & 353703119392801 & $6-20-89$ & 0930 & 11.11 & 19.00 & 245 & 30.0 & 23.5 & 755 \\
\hline $27 \mathrm{~S} / 22 \mathrm{E}-$ & 18D1M & 353512119390901 & $6-23-89$ & 0830 & 14.12 & 18.00 & 257 & 24.0 & 22.5 & 750 \\
\hline $29 \mathrm{~S} / 22 \mathrm{E}-$ & $2 \mathrm{C} 1 \mathrm{M}$ & 352629119345001 & $6-22-89$ & 1130 & 6.02 & 13.40 & 253 & 35.5 & 22.0 & 750 \\
\hline \multirow[t]{4}{*}{$32 \mathrm{~S} / 25 \mathrm{E}-$} & 12R3M & 350907119140501 & $6-29-89$ & 1800 & 12.79 & 19.00 & 298 & 29.0 & 22.0 & 755 \\
\hline & 23B1M & 350812119153101 & $7-11-89$ & 1530 & 7.53 & 18.40 & 310 & 34.5 & 23.0 & 755 \\
\hline & & & $7-11-89$ & 1600 & 7.53 & 18.40 & 310 & 34.5 & 23.0 & 755 \\
\hline & 29D1M & 350720119191601 & $7-11-89$ & 1000 & 8.37 & 14.30 & 380 & 28.0 & 23.0 & 750 \\
\hline \multirow[t]{4}{*}{$32 \mathrm{~S} / 26 \mathrm{E}-$} & 9R1M & 350912119105101 & $7-19-89$ & 1330 & 6.35 & 21.00 & 298 & 35.0 & 22.0 & 755 \\
\hline & 19D1M & 350812119135801 & $7-11-89$ & 1730 & 5.63 & 16.70 & 317 & 37.0 & 21.5 & 755 \\
\hline & $22 \mathrm{M} 1 \mathrm{M}$ & 350747119104701 & $7-18-89$ & 1800 & 16.11 & 22.40 & 334 & 38.0 & 22.0 & 755 \\
\hline & $25 \mathrm{~K} 1 \mathrm{M}$ & 350648119143101 & $7-18-89$ & 1530 & 6.28 & 22.50 & 364 & 37.0 & 23.0 & 755 \\
\hline $32 \mathrm{~S} / 27 \mathrm{E}-$ & $34 \mathrm{H} 2 \mathrm{M}$ & 350618119032401 & $7-10-89$ & 1800 & 5.30 & 17.40 & 301 & 38.0 & 23.5 & 750 \\
\hline $12 \mathrm{~N} / 20 \mathrm{~W}-$ & $32 \mathrm{~K} 1 \mathrm{~S}$ & 350446119021201 & $6-30-89$ & 0900 & 11.68 & 24.90 & 362 & 25.0 & 22.0 & 755 \\
\hline $12 \mathrm{~N} / 21 \mathrm{~W}-$ & $34 \mathrm{E} 2 \mathrm{~S}$ & 350502119070201 & $7-10-89$ & 1400 & 13.19 & 19.30 & 418 & 35.5 & 22.5 & 750 \\
\hline \multicolumn{11}{|c|}{ Alluvium-fan zone -- East-side alluvium (SN) subzone } \\
\hline 18S/19E- & 9J2M & 362236119541701 & $5-31-89$ & 1230 & 7.77 & 16.40 & 209 & 29.0 & 21.0 & 760 \\
\hline \multirow[t]{2}{*}{$18 \mathrm{~S} / 20 \mathrm{E}-$} & $15 \mathrm{~A} 2 \mathrm{M}$ & 362218119464901 & $5-31-89$ & 1800 & 9.39 & 15.30 & 236 & 34.0 & 21.0 & 750 \\
\hline & 31D1M & 361940119510001 & $5-31-89$ & 1530 & 5.41 & 12.10 & 214 & 33.0 & 22.0 & 750 \\
\hline $18 \mathrm{~S} / 21 \mathrm{E}-$ & 19D1M & 362125119443701 & $5-23-89$ & 1630 & 9.10 & 14.10 & 235 & 27.0 & 20.0 & 760 \\
\hline \multirow[t]{5}{*}{$19 \mathrm{~S} / 20 \mathrm{E}-$} & $5 \mathrm{~A} 1 \mathrm{M}$ & 361848119485701 & $8-11-89$ & 1515 & 6.24 & 20.40 & 218 & 33.5 & 23.5 & 755 \\
\hline & & & $8-11-89$ & 1615 & 6.24 & 20.40 & 218 & 33.5 & 23.5 & 755 \\
\hline & $11 \mathrm{R} 1 \mathrm{M}$ & 361703119454501 & $6-01-89$ & 0915 & 7.90 & 12.90 & 223 & 26.0 & 19.5 & 760 \\
\hline & 22A2M & 361609119464901 & $5-31-89$ & 1850 & 7.70 & 14.80 & 222 & 31.0 & 23.0 & 755 \\
\hline & $35 \mathrm{D} 2 \mathrm{M}$ & 361424119464701 & $5-25-89$ & 1100 & 7.83 & 17.72 & 215 & 22.0 & 20.5 & 760 \\
\hline \multirow[t]{2}{*}{$19 \mathrm{~S} / 21 \mathrm{E}-$} & 17R1M & 361610119423001 & $5-26-89$ & 1000 & 8.34 & 15.20 & 230 & 19.0 & 20.0 & 760 \\
\hline & $32 \mathrm{~A} 2 \mathrm{M}$ & 361414119423001 & $5-24-89$ & 1630 & 7.32 & 21.53 & 222 & 27.0 & 19.5 & 755 \\
\hline \multirow[t]{3}{*}{$20 \mathrm{~S} / 20 \mathrm{E}-$} & 9N1M & 361149119485501 & $6-01-89$ & 1000 & 7.09 & 16.80 & 200 & 31.0 & 21.0 & 750 \\
\hline & 10D1M & 361232119475001 & $6-07-89$ & 1600 & 3.95 & 15.35 & 207 & 31.5 & 21.0 & 750 \\
\hline & 29D1M & 361002119495901 & $5-25-89$ & 1830 & 6.40 & 16.90 & 195 & 28.0 & 20.0 & 760 \\
\hline \multirow[t]{2}{*}{ 20S/21E- } & 13B1M & 361148119383901 & $6-26-89$ & 1600 & 5.26 & 19.72 & 214 & 31.0 & 21.5 & 755 \\
\hline & 36Q2M & 360856119384001 & $6-08-89$ & 1500 & 4.38 & 19.60 & 208 & 32.0 & 21.0 & 750 \\
\hline $27 \mathrm{~S} / 23 \mathrm{E}-$ & 11R1M & 353515119272001 & $6-26-89$ & 1645 & 13.80 & 19.00 & 268 & 32.0 & 24.0 & 755 \\
\hline $28 \mathrm{~S} / 23 \mathrm{E}-$ & $25 \mathrm{~K} 1 \mathrm{M}$ & 352751119263401 & $6-22-89$ & 1530 & 6.70 & 17.80 & 264 & 39.0 & 22.0 & 750 \\
\hline $30 \mathrm{~S} / 28 \mathrm{E}-$ & $28 \mathrm{~A} 4 \mathrm{M}$ & 351745118575401 & $7-17-89$ & 1330 & 9.05 & 23.20 & 361 & 33.0 & 22.0 & 755 \\
\hline $31 \mathrm{~S} / 28 \mathrm{E}-$ & 21D1M & 351321118590201 & $6-28-89$ & 1730 & 5.95 & 18.80 & 322 & 31.5 & 22.0 & 755 \\
\hline $32 \mathrm{~S} / 27 \mathrm{E}-$ & $2 \mathrm{H} 1 \mathrm{M}$ & 351025119021901 & $7-19-89$ & 0830 & 11.45 & 22.00 & 293 & 30.0 & 22.0 & 755 \\
\hline
\end{tabular}


Table 6. Location, characteristics, and field measurements of sampled wells, Tulare Basin, California-Continued

\begin{tabular}{|c|c|c|c|c|c|c|c|c|c|c|}
\hline State w & 11 No. & Station No. & Data & Time & $\begin{array}{l}\text { Water } \\
\text { level }\end{array}$ & $\begin{array}{l}\text { Depth } \\
\text { of } \\
\text { well }\end{array}$ & $\begin{array}{l}\text { Altitude } \\
\text { of land } \\
\text { surface }\end{array}$ & $\begin{array}{l}\text { Temper- } \\
\text { ature, } \\
\text { air }\end{array}$ & $\begin{array}{l}\text { Temper- } \\
\text { ature, } \\
\text { water }\end{array}$ & $\begin{array}{c}\text { Baro- } \\
\text { metric } \\
\text { pres- } \\
\text { sure }\end{array}$ \\
\hline \multicolumn{11}{|c|}{ Basin zone -- West-side basin (BW) subzone } \\
\hline \multirow[t]{3}{*}{$18 \mathrm{~S} / 19 \mathrm{E}-$} & $15 \mathrm{~N} 1 \mathrm{M}$ & 362131119541501 & $5-31-89$ & 1140 & 3.87 & 13.50 & 211 & 26.0 & 19.5 & 760 \\
\hline & $21 \mathrm{~N} 3 \mathrm{M}$ & 362035119552001 & $5-31-89$ & 1620 & 5.00 & 13.30 & 218 & 34.5 & 22.0 & 755 \\
\hline & $34 \mathrm{~N} 1 \mathrm{M}$ & 361850119541201 & $5-30-89$ & 1930 & 7.38 & 14.90 & 215 & 27.5 & 20.0 & 755 \\
\hline 19S/19E- & $14 \mathrm{R} 1 \mathrm{M}$ & 361612119520701 & $5-30-89$ & 1630 & 6.96 & 15.00 & 213 & 31.0 & 22.5 & 755 \\
\hline 20S/19E- & $13 \mathrm{M} 1 \mathrm{M}$ & 361122119520201 & $6-07-89$ & 1400 & 5.13 & 21.15 & 204 & 31.0 & 21.5 & 750 \\
\hline \multirow{2}{*}{$25 \mathrm{~S} / 21 \mathrm{E}-$} & $7 \mathrm{~B} 3 \mathrm{M}$ & 354633119450403 & $5-09-89$ & 1815 & 8.85 & 23.10 & 217 & - & 16.0 & -- \\
\hline & $17 \mathrm{H} 1 \mathrm{M}$ & 354513119433001 & $6-21-89$ & 1330 & 8.15 & 17.10 & 220 & 32.0 & 25.0 & 755 \\
\hline \multirow[t]{2}{*}{$26 \mathrm{~S} / 21 \mathrm{E}-$} & 2R1M & 354120119401701 & $6-21-89$ & 0830 & 13.12 & 17.50 & 234 & 26.5 & 21.0 & 755 \\
\hline & $14 \mathrm{R} 1 \mathrm{M}$ & 353935119401701 & $6-29-89$ & 1130 & 3.53 & 17.80 & 237 & 26.0 & 22.5 & 760 \\
\hline $27 \mathrm{~S} / 22 \mathrm{E}-$ & $20 \mathrm{M} 1 \mathrm{M}$ & 353343119375601 & $7-12-89$ & 1430 & 3.30 & 20.60 & 242 & 38.0 & 26.0 & 760 \\
\hline $32 \mathrm{~S} / 27 \mathrm{E}-$ & $7 \mathrm{R} 2 \mathrm{M}$ & 350909119063201 & $7-19-89$ & 1100 & 8.23 & 22.00 & 290 & 32.0 & 22.5 & 755 \\
\hline \multicolumn{11}{|c|}{ Basin zone -- East-side (BE) subzone } \\
\hline $19 \mathrm{~S} / 20 \mathrm{E}-$ & 32D1M & 361415119500001 & $6-07-89$ & 1730 & 5.15 & 16.52 & 208 & 30.5 & 22.0 & 750 \\
\hline $20 \mathrm{~S} / 21 \mathrm{E}-$ & $17 \mathrm{~A} 1 \mathrm{M}$ & 361140119422801 & 6-26-89 & 1400 & 7.65 & 19.80 & 212 & 32.5 & 22.0 & 755 \\
\hline \multirow[t]{2}{*}{$25 \mathrm{~S} / 21 \mathrm{E}-$} & $12 \mathrm{D} 2 \mathrm{M}$ & 354631119400001 & $7-07-89$ & 1015 & 6.49 & 18.51 & 210 & 29.0 & 24.0 & 755 \\
\hline & $26 \mathrm{P} 2 \mathrm{M}$ & 354304119405101 & $6-21-89$ & 1015 & 6.34 & 18.40 & 221 & - & 20.0 & 755 \\
\hline \multirow{2}{*}{$25 \mathrm{~S} / 22 \mathrm{E}-$} & $19 \mathrm{~N} 1 \mathrm{M}$ & 354358119390501 & $7-12-89$ & 1900 & 5.62 & 20.0 & 218 & 35.0 & 21.0 & 760 \\
\hline & $34 \mathrm{~A} 2 \mathrm{M}$ & 354255119344601 & $6-20-89$ & 1830 & 14.70 & 18.00 & 221 & 32.0 & 24.0 & 755 \\
\hline \multirow{4}{*}{$26 \mathrm{~S} / 22 \mathrm{E}-$} & $7 \mathrm{~A} 1 \mathrm{M}$ & 354127119380901 & $7-12-89$ & 1600 & 10.12 & 19.69 & 224 & 35.5 & 22.0 & 760 \\
\hline & 20G1M & 353925119371801 & $6-20-89$ & 1100 & 7.45 & 14.40 & 229 & 28.0 & 23.0 & 750 \\
\hline & & & $6-20-89$ & 1200 & 7.45 & 14.40 & 229 & 28.0 & 23.0 & 750 \\
\hline & 28R2M & 353751119355001 & $6-20-89$ & 1545 & 12.50 & 22.00 & 246 & 32.0 & 23.0 & 755 \\
\hline $26 \mathrm{~S} / 23 \mathrm{E}-$ & $8 \mathrm{R} 3 \mathrm{M}$ & 354027119302901 & 6-20-89 & 1530 & 11.66 & 17.50 & 227 & 32.5 & 23.0 & 750 \\
\hline \multirow{4}{*}{$27 \mathrm{~S} / 22 \mathrm{E}-$} & $4 \mathrm{E} 2 \mathrm{M}$ & 353635119365801 & $6-21-89$ & 1600 & 3.18 & 14.30 & 238 & 35.0 & 21.5 & 750 \\
\hline & $15 \mathrm{~A} 2 \mathrm{M}$ & 353511119345301 & $7-11-89$ & 1550 & 5.48 & 18.70 & 238 & 37.0 & 26.0 & 755 \\
\hline & $17 \mathrm{R} 3 \mathrm{M}$ & 353425119370401 & $6-22-89$ & 1130 & 4.40 & 15.92 & 238 & 30.0 & 24.0 & 755 \\
\hline & 23D4M & 353410119344601 & $7-11-89$ & 1830 & 5.81 & 20.80 & 238 & 36.0 & 23.5 & 755 \\
\hline \multirow[t]{3}{*}{$28 \mathrm{~S} / 22 \mathrm{E}-$} & $5 \mathrm{~A} 1 \mathrm{M}$ & 353142119370501 & $6-22-89$ & 1000 & 4.73 & 12.60 & 243 & 28.0 & 22.0 & 755 \\
\hline & $15 \mathrm{~N} 6 \mathrm{M}$ & 352907119354501 & $7-12-89$ & 1100 & 7.40 & 21.00 & 247 & 31.0 & 23.0 & 760 \\
\hline & & & $7-12-89$ & 1200 & 7.40 & 21.00 & 247 & 31.0 & 23.0 & 760 \\
\hline $28 \mathrm{~S} / 23 \mathrm{E}-$ & $3 \mathrm{H} 1 \mathrm{M}$ & 353119119282601 & $6-22-89$ & 1700 & 11.80 & 19.00 & 250 & 40.0 & 21.0 & 750 \\
\hline $29 \mathrm{~S} / 24 \mathrm{E}-$ & $5 \mathrm{Q} 1 \mathrm{M}$ & 352541119250801 & $6-22-89$ & 1400 & 3.95 & 15.50 & 280 & 38.0 & 23.0 & 750 \\
\hline \multirow{2}{*}{$30 \mathrm{~S} / 28 \mathrm{E}-$} & $2 \mathrm{~N} 1 \mathrm{M}$ & 352024118565501 & $7-18-89$ & 0800 & 14.85 & 23.00 & 379 & 27.0 & 22.0 & 750 \\
\hline & & & $7-18-89$ & 0900 & 14.85 & 23.00 & 379 & 27.0 & 22.0 & 750 \\
\hline $31 \mathrm{~S} / 25 \mathrm{E}-$ & $36 \mathrm{H} 2 \mathrm{M}$ & 351123119140601 & $6-29-89$ & 1400 & 7.59 & 17.70 & 286 & 26.5 & 23.0 & 755 \\
\hline \multirow[t]{3}{*}{$31 \mathrm{~S} / 28 \mathrm{E}-$} & $9 \mathrm{C} 1 \mathrm{M}$ & 351507118584501 & $7-17-89$ & 1530 & 12.95 & 24.00 & 335 & 35.0 & 23.0 & 755 \\
\hline & & & $7-17-89$ & 1600 & 12.95 & 24.00 & 335 & 35.0 & 23.0 & 755 \\
\hline & $22 \mathrm{~N} 2 \mathrm{M}$ & 351233118575701 & $6-29-89$ & 0830 & 9.88 & 17.10 & 317 & 21.0 & 21.0 & 755 \\
\hline $32 \mathrm{~S} / 28 \mathrm{E}-$ & $17 \mathrm{C} 2 \mathrm{M}$ & 350859118595201 & $7-17-89$ & 1800 & 11.89 & 23.70 & 295 & 36.5 & 23.0 & 755 \\
\hline
\end{tabular}

\begin{tabular}{llllllllllll}
\hline \multicolumn{10}{c}{ Tulare Lake zone -- Northeastern-margin (NEM) subzone } \\
\hline 20S/20E- & 15M2M & 361122119475001 & $5-25-89$ & 1630 & 6.82 & 17.70 & 204 & 27.0 & 21.0 & 760 \\
20S/21E- & 19D1M & 361054119443601 & $5-24-89$ & 1100 & 6.89 & 17.20 & 206 & 22.5 & 19.5 & 760 \\
20S/22E- & 33R2M & 360820119350801 & $6-08-89$ & 0930 & 11.14 & 16.20 & 211 & 24.0 & 20.0 & 750 \\
21S/21E- & 2G1M & 360752119401201 & $6-08-89$ & 1200 & 7.70 & 19.60 & 200 & 28.0 & 21.0 & 750 \\
21S/22E- & 16C2M & 360620119355301 & $6-26-89$ & 1800 & 4.12 & 20.03 & 198 & 32.0 & 21.5 & 755 \\
& 27A3M & 360442119341701 & $6-09-89$ & 0800 & 3.19 & 21.20 & 197 & 20.5 & 20.0 & 750 \\
22S/23E- & 7R1M & 360124119310401 & $6-27-89$ & 0930 & 6.19 & 17.88 & 201 & 26.0 & 21.0 & 755 \\
& 27M1M & 355905119285201 & $6-27-89$ & 1500 & 6.15 & 20.61 & 198 & 35.0 & 22.0 & 755
\end{tabular}


Table 6. Location, characteristics, and field measurements of sampled wells, Tulare Basin, California-Continued

\begin{tabular}{|c|c|c|c|c|c|c|c|c|c|c|}
\hline State $\mathrm{w}$ & ll No. & Station No. & Data & Time & $\begin{array}{l}\text { Water } \\
\text { level }\end{array}$ & $\begin{array}{l}\text { Depth } \\
\text { of } \\
\text { well }\end{array}$ & $\begin{array}{l}\text { Altitude } \\
\text { of land } \\
\text { surface }\end{array}$ & $\begin{array}{l}\text { Temper- } \\
\text { ature, } \\
\text { air }\end{array}$ & $\begin{array}{l}\text { Temper- } \\
\text { ature, } \\
\text { water }\end{array}$ & $\begin{array}{c}\text { Baro- } \\
\text { metric } \\
\text { pres- } \\
\text { sure }\end{array}$ \\
\hline \multicolumn{11}{|c|}{ Tulare Lake zone -- Southern/Western-margin (SWM) subzone } \\
\hline 20S/19E- & $25 \mathrm{~A} 3 \mathrm{M}$ & 360955119510301 & $6-07-89$ & 1130 & 7.39 & 20.50 & 198 & 27.0 & 21.0 & 750 \\
\hline \multirow[t]{2}{*}{ 21S/19E- } & 1D3M & 360814119522801 & $6-07-89$ & 0930 & 5.66 & 17.97 & 193 & 22.0 & 21.0 & 750 \\
\hline & 16R2M & 360538119550601 & $6-06-89$ & 1730 & 7.45 & 20.45 & 198 & 33.0 & 22.5 & 750 \\
\hline 22S/19E- & $28 \mathrm{~J} 1 \mathrm{M}$ & 355858119550201 & $6-05-89$ & 1830 & 5.13 & 20.05 & 187 & 33.0 & 19.5 & 755 \\
\hline $23 \mathrm{~S} / 20 \mathrm{E}-$ & 14B1M & 355602119463301 & $6-28-89$ & 1800 & 7.46 & 22.40 & 192 & 31.0 & 23.0 & 760 \\
\hline \multirow[t]{4}{*}{$23 \mathrm{~S} / 23 \mathrm{E}-$} & $15 \mathrm{M} 1 \mathrm{M}$ & 355530119285201 & $6-27-89$ & 1130 & 7.60 & 20.70 & 199 & 29.0 & 21.0 & 755 \\
\hline & & & $6-27-89$ & 1230 & 7.60 & 20.70 & 199 & 29.0 & 21.0 & 755 \\
\hline & $26 \mathrm{G} 1 \mathrm{M}$ & 355404119271401 & $6-28-89$ & 1200 & 6.94 & 20.35 & 209 & 24.5 & 20.0 & 760 \\
\hline & 31D2M & 355317119320301 & $6-27-89$ & 1830 & 7.10 & 21.90 & 198 & 33.0 & 21.0 & 755 \\
\hline \multirow{2}{*}{$243 / 23 D^{-1}$} & $4 \mathrm{~K} 1 \mathrm{M}$ & 355210119291201 & $6-28-89$ & 1400 & 6.47 & 18.20 & 209 & 28.0 & 20.5 & 760 \\
\hline & & Tular & Lone & we & 000 & TLB) su & zone & & & \\
\hline \multirow[t]{2}{*}{$21 \mathrm{~S} / 19 \mathrm{E}-$} & $23 \mathrm{~A} 1 \mathrm{M}$ & 360537119523801 & 6-06-89 & 1500 & 4.04 & 18.62 & 182 & 32.0 & 22.5 & 750 \\
\hline & $35 \mathrm{~J} 1 \mathrm{M}$ & 360325119523801 & $6-06-89$ & 1130 & 3.43 & 19.80 & 178 & 26.0 & 20.5 & 755 \\
\hline \multirow[t]{3}{*}{$21 \mathrm{~S} / 20 \mathrm{E}-$} & 10Q1M & 360642119474801 & $6-27-89$ & 0930 & 4.70 & 22.82 & 182 & 32.0 & 21.0 & 760 \\
\hline & $26 \mathrm{D} 1 \mathrm{M}$ & 360445119470201 & $6-27-89$ & 1500 & 3.72 & 12.60 & 179 & 33.0 & 24.0 & 755 \\
\hline & 28B1M & 360446119484401 & $6-27-89$ & 1200 & 4.96 & 22.50 & 179 & 33.0 & 21.0 & 760 \\
\hline 21S/22E- & $19 \mathrm{E} 1 \mathrm{M}$ & 360521119381401 & $6-08-89$ & 1630 & 3.65 & 17.70 & 187 & 34.0 & 21.0 & 750 \\
\hline \multirow{2}{*}{$22 \mathrm{~S} / 19 \mathrm{E}-$} & 9H1M & 360148119544801 & $6-06-89$ & 0900 & 5.99 & 19.34 & 182 & 21.0 & 19.5 & 755 \\
\hline & $13 \mathrm{~J} 1 \mathrm{M}$ & 360048119510801 & $6-05-89$ & 1600 & 8.22 & 20.60 & 180 & 30.0 & 21.5 & 755 \\
\hline \multirow[t]{4}{*}{$22 \mathrm{~S} / 21 \mathrm{E}-$} & 13D1M & 360117119392701 & $6-28-89$ & 1030 & 9.03 & 22.90 & 184 & 24.0 & 22.5 & 760 \\
\hline & $16 \mathrm{~B} 1 \mathrm{M}$ & 360116119420301 & $6-28-89$ & 0845 & 5.10 & 20.20 & 183 & 20.0 & 19.0 & 760 \\
\hline & 18D2M & 360115119445801 & $6-27-89$ & 1730 & 7.35 & 20.20 & 183 & 32.0 & 24.0 & 755 \\
\hline & 28R1M & 355841119415001 & $6-28-89$ & 1530 & 5.00 & 21.60 & 187 & 31.0 & 24.0 & 760 \\
\hline \multirow[t]{5}{*}{$22 \mathrm{~S} / 22 \mathrm{E}-$} & 9N1M & 360118119362401 & $6-28-89$ & 1215 & 2.50 & 22.80 & 187 & 28.0 & 22.5 & 760 \\
\hline & & & $6-28-89$ & 1315 & 2.25 & 22.80 & 187 & 28.0 & 22.5 & 760 \\
\hline & 14D1M & 360115119341501 & 6-09-89 & 1000 & 2.85 & 20.55 & 191 & 24.0 & 21.0 & 750 \\
\hline & 22R1M & 355938119341601 & $6-19-89$ & 1430 & 3.49 & 19.70 & 191 & 33.0 & 21.0 & 750 \\
\hline & $35 \mathrm{~N} 1 \mathrm{M}$ & 355752119341401 & $6-19-89$ & 1630 & 6.39 & 19.80 & 192 & 32.5 & 22.0 & 750 \\
\hline 23S/19E- & $2 \mathrm{~A} 1 \mathrm{M}$ & 355743119524201 & $6-05-89$ & 1400 & 3.43 & 22.00 & 187 & 27.5 & 21.0 & 755 \\
\hline 23S/21E- & $8 \mathrm{R} 1 \mathrm{M}$ & 355604119430201 & $6-28-89$ & 0930 & 4.65 & 19.85 & 188 & 24.0 & 22.0 & 760 \\
\hline 23S/22E- & 6R1M & 355657119374001 & $6-19-89$ & 1830 & 6.88 & 20.40 & 189 & 35.0 & 21.0 & 750 \\
\hline \multirow{2}{*}{$23 \mathrm{~S} / 23 \mathrm{E}-$} & $7 \mathrm{M} 1 \mathrm{M}$ & 355622119320901 & $6-27-89$ & 1630 & 3.98 & 22.05 & 193 & 33.0 & 21.0 & 755 \\
\hline & & 355622119320901 & $6-27-89$ & 1730 & 3.98 & 22.05 & 193 & 33.0 & 21.0 & 755 \\
\hline \multicolumn{11}{|c|}{ Miscellaneous sites } \\
\hline $26 \mathrm{~S} / 22 \mathrm{E}-$ & 34P1M & 353659119352501 & $6-20-89$ & 1300 & 6.00 & 17.90 & 249 & 30.0 & 23.0 & 755 \\
\hline \multirow[t]{3}{*}{$27 \mathrm{~S} / 23 \mathrm{E}-$} & $18 \mathrm{~A} 1 \mathrm{M}$ & 353500119313701 & $7-12-89$ & 1200 & 6.61 & 20.50 & 277 & 32.0 & 22.5 & 760 \\
\hline & 20R2M & 353329119303401 & $6-29-89$ & 0915 & 9.40 & 15.70 & 250 & 21.0 & 21.0 & 760 \\
\hline & & & $6-29-89$ & 1015 & 9.40 & 15.70 & 250 & 21.0 & 21.0 & 760 \\
\hline $32 \mathrm{~S} / 28 \mathrm{E}-$ & $30 \mathrm{C} 2 \mathrm{M}$ & 350719119004101 & $7-18-89$ & 1400 & 12.32 & 20.30 & 318 & 35.5 & 22.0 & 755 \\
\hline \multirow[t]{2}{*}{$32 \mathrm{~S} / 27 \mathrm{E}-$} & $10 \mathrm{~N} 1 \mathrm{M}$ & 350905119041201 & $6-29-89$ & 1030 & 10.78 & 18.50 & 282 & 26.0 & 22.5 & 760 \\
\hline & $16 \mathrm{R} 4 \mathrm{M}$ & 350815119042501 & $6-29-89$ & 1200 & 5.50 & 18.60 & 292 & 25.0 & 22.0 & 760 \\
\hline $32 \mathrm{~S} / 28 \mathrm{E}-$ & 18D2M & 350904119010901 & $7-18-89$ & 1030 & 3.47 & 20.00 & 281 & 31.5 & 22.5 & 755 \\
\hline
\end{tabular}


Table 7. Chemical analyses of major ions in water samples from selected wells, Tulare Basin, California

[State well No.: See well-numbering system on page VI. Results are in milligrams per liter, unless otherwise noted.

\begin{tabular}{|c|c|c|c|c|c|c|c|}
\hline State wel & 1 No. & Date & $\begin{array}{c}\text { Specific } \\
\text { conductance, } \\
\text { lab } \\
(\mu \mathrm{S} / \mathrm{cm})\end{array}$ & $\begin{array}{c}\mathrm{pH}, \\
\text { field } \\
\text { (standard } \\
\text { units) }\end{array}$ & $\begin{array}{l}\text { Calcium, } \\
\text { dissolved }\end{array}$ & $\begin{array}{c}\text { Magnesium, } \\
\text { dissolved }\end{array}$ & $\begin{array}{l}\text { Sodium, } \\
\text { dissolved }\end{array}$ \\
\hline \multicolumn{8}{|c|}{ Alluvium-fan zone -- West-side alluvium (CR) subzone } \\
\hline \multirow[t]{2}{*}{$25 \mathrm{~S} / 20 \mathrm{E}-$} & $15 \mathrm{~A} 4 \mathrm{M}$ & $7-12-89$ & 3,140 & 7.4 & 460 & 80 & 230 \\
\hline & 23P1M & $6-21-89$ & 3,810 & 7.3 & 470 & 84 & 400 \\
\hline \multirow{3}{*}{$25 \mathrm{~S} / 21 \mathrm{E}-$} & $29 \mathrm{~N} 1 \mathrm{M}$ & $6-21-89$ & 16,500 & 8.2 & 420 & 45 & 4,200 \\
\hline & 31P1M & $6-21-89$ & 27,200 & 7.3 & 1,000 & 340 & 5,200 \\
\hline & $33 \mathrm{~N} 1 \mathrm{M}$ & $6-21-89$ & 14,600 & 7.4 & 430 & 78 & 3,500 \\
\hline \multirow[t]{2}{*}{$26 \mathrm{~S} / 21 \mathrm{E}-$} & 16R1M & $7-11-89$ & 14,900 & 7.3 & 980 & 240 & 2,100 \\
\hline & 36Q1M & $6-20-89$ & 7,110 & 7.2 & 390 & 99 & 1,300 \\
\hline $27 \mathrm{~S} / 22 \mathrm{E}-$ & 18D1M & $6-23-89$ & 29,800 & 7.1 & 460 & 290 & 7,000 \\
\hline $29 \mathrm{~S} / 22 \mathrm{E}-$ & $2 \mathrm{C} 1 \mathrm{M}$ & $6-22-89$ & 3,320 & 8.0 & 22 & 8.9 & 630 \\
\hline \multirow[t]{4}{*}{$32 \mathrm{~S} / 25 \mathrm{E}-$} & $12 \mathrm{R} 3 \mathrm{M}$ & $6-29-89$ & 43,500 & 7.5 & 480 & 1,000 & 11,000 \\
\hline & 23B1M & $7-11-89$ & 5,040 & 7.7 & 500 & 190 & 610 \\
\hline & & $7-11-89$ & 5,050 & 7.7 & 520 & 180 & 580 \\
\hline & 29D1M & $7-11-89$ & 4,860 & 7.0 & 720 & 160 & 190 \\
\hline \multirow[t]{4}{*}{$32 \mathrm{~S} / 26 \mathrm{E}-$} & 9R1M & $7-19-89$ & 3,350 & 7.6 & 550 & 97 & 250 \\
\hline & 19D1M & $7-11-89$ & 4,290 & 7.9 & 520 & 240 & 370 \\
\hline & $22 \mathrm{M} 1 \mathrm{M}$ & $7-18-89$ & 8,660 & 7.7 & 480 & 180 & 1,700 \\
\hline & $25 \mathrm{~K} 1 \mathrm{M}$ & $7-18-89$ & 16,100 & 8.0 & 270 & 420 & 3,600 \\
\hline $32 \mathrm{~S} / 27 \mathrm{E}-$ & $34 \mathrm{H} 2 \mathrm{M}$ & $7-10-89$ & 11,000 & 7.4 & 380 & 320 & 2,100 \\
\hline $12 \mathrm{~N} / 20 \mathrm{~W}-$ & $32 \mathrm{~K} 1 \mathrm{~S}$ & $6-30-89$ & 6,590 & 7.6 & 450 & 160 & 960 \\
\hline $12 \mathrm{~N} / 21 \mathrm{~W}-$ & $34 \mathrm{E} 2 \mathrm{~S}$ & $7-10-89$ & 1,410 & 7.3 & 220 & 12 & 55 \\
\hline \multicolumn{8}{|c|}{ Alluvium-fan zone -- East-side alluvium (SN) subzone } \\
\hline 18S/19E- & $9 \mathrm{~J} 2 \mathrm{M}$ & $5-31-89$ & 4,400 & 7.1 & 87 & 95 & 840 \\
\hline \multirow[t]{2}{*}{$18 \mathrm{~S} / 20 \mathrm{E}-$} & $15 \mathrm{~A} 2 \mathrm{M}$ & $5-31-89$ & 607 & 6.4 & 57 & 20 & 42 \\
\hline & 31D1M & $5-31-89$ & 2,000 & 7.1 & 150 & 51 & 210 \\
\hline $18 \mathrm{~S} / 21 \mathrm{E}-$ & 19D1M & $5-23-89$ & 1,600 & 6.7 & 91 & 36 & 210 \\
\hline \multirow{5}{*}{$19 \mathrm{~S} / 20 \mathrm{E}-$} & $5 \mathrm{~A} 1 \mathrm{M}$ & $8-11-89$ & 288 & 7.2 & 28 & 7.9 & 22 \\
\hline & & $8-11-89$ & 289 & 7.2 & 28 & 7.9 & 22 \\
\hline & 11R1M & 6-01-89 & 1,330 & 7.2 & 45 & 19 & 250 \\
\hline & $22 \mathrm{~A} 2 \mathrm{M}$ & $5-31-89$ & 1,330 & 6.7 & 160 & 31 & 82 \\
\hline & $35 \mathrm{D} 2 \mathrm{M}$ & $5-25-89$ & 308 & 7.9 & 31 & 11 & 22 \\
\hline \multirow[t]{2}{*}{ 19S/21E- } & 17R1M & $5-26-89$ & 613 & 7.4 & 58 & 14 & 58 \\
\hline & $32 \mathrm{~A} 2 \mathrm{M}$ & $5-24-89$ & 1,730 & 7.2 & 76 & 30 & 270 \\
\hline \multirow[t]{3}{*}{$20 S / 20 \mathrm{E}-$} & $9 \mathrm{~N} 1 \mathrm{M}$ & $6-01-89$ & 13,100 & 6.6 & 360 & 630 & 2,600 \\
\hline & 10D1M & $6-07-89$ & 16,800 & 7.3 & 250 & 380 & 3,900 \\
\hline & 29D1M & $5-25-89$ & 7,890 & 6.6 & 450 & 530 & 1,100 \\
\hline \multirow[t]{2}{*}{$20 \mathrm{~S} / 21 \mathrm{E}-$} & 13B1M & $6-26-89$ & 2,480 & 7.5 & 32 & 18 & 530 \\
\hline & 36Q2M & 6-08-89 & 4,930 & 7.1 & 180 & 100 & 820 \\
\hline $27 \mathrm{~S} / 23 \mathrm{E}-$ & 11R1M & $6-26-89$ & 1,210 & 7.4 & 21 & 1.6 & 240 \\
\hline $28 \mathrm{~S} / 23 \mathrm{E}-$ & $25 \mathrm{~K} 1 \mathrm{M}$ & $6-22-89$ & 928 & 8.2 & 6.4 & .51 & 190 \\
\hline $30 \mathrm{~S} / 28 \mathrm{E}-$ & $28 \mathrm{~A} 4 \mathrm{M}$ & $7-17-89$ & 1,070 & 7.7 & 40 & 17 & 160 \\
\hline $31 \mathrm{~S} / 28 \mathrm{E}-$ & 21D1M & $6-28-89$ & 1,030 & 7.3 & 21 & 9.8 & 190 \\
\hline $32 \mathrm{~S} / 27 \mathrm{E}-$ & $2 \mathrm{H} 1 \mathrm{M}$ & $7-19-89$ & 15,400 & 7.8 & 130 & 85 & 3,800 \\
\hline
\end{tabular}


$\mu \mathrm{S} / \mathrm{cm}$, microsiemen per centimeter at 25 degrees Celsius; <, actual value less than value shown; --, not analyzed]

\begin{tabular}{cccccccr}
\hline $\begin{array}{c}\text { Potassium, } \\
\text { dissolved }\end{array}$ & $\begin{array}{c}\text { Bicarbonate } \\
\left.\text { (as } \mathrm{HCO}_{3}\right)\end{array}$ & $\begin{array}{c}\text { Sulfate, } \\
\text { dissolved }\end{array}$ & $\begin{array}{l}\text { Chloride, } \\
\text { dissolved }\end{array}$ & $\begin{array}{l}\text { Fluoride, } \\
\text { dissolved }\end{array}$ & $\begin{array}{c}\text { Bromide, } \\
\text { dissolved }\end{array}$ & $\begin{array}{c}\text { Silica, } \\
\text { dissolved }\end{array}$ & $\begin{array}{c}\text { Solids, } \\
\text { sum of } \\
\text { constituents, } \\
\text { dissolved }\end{array}$ \\
\hline \multicolumn{7}{c}{ Alluvium-fan zone -- West-side alluvium (CR) subzone } \\
\hline .70 & 107 & 1,900 & 67 & .20 & 1.0 & 38 & 2,840 \\
4.6 & 229 & 2,100 & 97 & .30 & .53 & 44 & 3,370 \\
5.4 & 154 & 9,500 & 640 & .20 & 1.1 & 32 & 15,100 \\
1.4 & 160 & 4,000 & 8,200 & 1.1 & 57 & 40 & 19,000 \\
1.6 & 295 & 6,700 & 1,500 & 1.2 & 3.0 & 21 & 12,400 \\
.90 & 151 & 2,400 & 3,700 & 5.10 & 13 & 36 & 10,400 \\
2.2 & 234 & 4,200 & 59 & 1.9 &.- & 22 & 6,210 \\
6.7 & 379 & 5,800 & 8,400 & 2.3 & 32 & 56 & 22,300 \\
3.6 & 380 & 340 & 620 & 2.6 & 5.0 & 37 & 1,930 \\
100 & 463 & 24,000 & 6,200 & 2.8 & 9.9 & 25 & 43,200 \\
7.5 & 88 & 3,100 & 200 & 2.7 & .28 & 22 & 4,680 \\
7.0 & 88 & 3,100 & 170 & 2.7 & .28 & 22 & 4,630 \\
13 & 505 & 1,700 & 360 & .60 & .82 & 24 & 3,420 \\
23 & 163 & 2,200 & 21 & 7.8 & .11 & 13 & 3,260 \\
21 & 99 & 2,600 & 140 & 5.5 & .08 & 7.7 & 3,970 \\
16 & 129 & 5,000 & 290 & 8.5 & .50 & 14 & 7,780 \\
27 & 159 & 9,200 & 1,000 & 6.3 & .49 & 11 & 14,700 \\
3.8 & 251 & 6,000 & 550 & 1.8 & 3.1 & 31 & 9,480 \\
17 & 118 & 3,600 & 230 & 2.1 & 1.5 & 53 & 5,750 \\
4.3 & 227 & 340 & 120 & .90 & .24 & 28 & 972
\end{tabular}

\begin{tabular}{cccccccr}
\hline \multicolumn{7}{c}{ Alluvium-fan zone - East-side alluvium (SN) subzone } \\
\hline 2.4 & 444 & 1,600 & 300 & 0.80 & 0.11 & 32 & 3,180 \\
1.6 & 115 & 140 & 24 & .20 & .06 & 31 & 409 \\
.90 & 349 & 310 & 72 & 1.3 & .27 & 38 & 1,450 \\
1.6 & 248 & 330 & 120 & .20 & .68 & 31 & 1,070 \\
.80 & 110 & 29 & 7.2 & .20 & .01 & 25 & 176 \\
.80 & 110 & 29 & 7.2 & .20 & .01 & 25 & 176 \\
.80 & 607 & 170 & 21 & .40 & .03 & 25 & 851 \\
.90 & 441 & 160 & 59 & .20 & .33 & 33 & 810 \\
.50 & 167 & 16 & 4.9 & .40 & .01 & 33 & 203 \\
.30 & 201 & 98 & 12 & .40 & .05 & 40 & 416 \\
.70 & 580 & 180 & 110 & .50 & .26 & 42 & 1,130 \\
5.4 & 402 & 8,500 & 400 & 1.2 & 1.3 & 46 & 12,700 \\
5.3 & 667 & 7,300 & 1,900 & 1.0 & 3.4 & 56 & 14,200 \\
3.5 & 355 & 4,700 & 310 & .90 & .65 & 51 & 7,440 \\
1.1 & 804 & 320 & 150 & 1.7 & .18 & 36 & 1,660 \\
2.2 & 587 & 1,200 & 700 & .90 & .05 & 48 & 3,380 \\
.50 & 254 & 130 & 150 & 1.1 & .36 & 63 & 734 \\
.10 & 161 & 90 & 140 & 2.0 & .42 & 83 & 599 \\
4.2 & 279 & 89 & 90 & .40 & .13 & 48 & 702 \\
.90 & 485 & 58 & 51 & 2.5 & .25 & 39 & 637 \\
11 & 687 & 7,000 & 1,400 & 6.0 & 1.8 & 29 & 12,900
\end{tabular}


Table 7. Chemical analyses of major ions in water samples from selected wells, Tulare Basin, California--

\begin{tabular}{|c|c|c|c|c|c|c|c|}
\hline State we & No. & Date & $\begin{array}{c}\text { Specific } \\
\text { conductance, } \\
\text { lab } \\
(\mu \mathrm{S} / \mathrm{cm})\end{array}$ & $\begin{array}{c}\mathrm{pH}, \\
\text { field } \\
\text { (standard } \\
\text { units) }\end{array}$ & $\begin{array}{l}\text { Calcium, } \\
\text { dissolved }\end{array}$ & $\begin{array}{l}\text { Magnesium, } \\
\text { dissolved }\end{array}$ & $\begin{array}{l}\text { Sodium, } \\
\text { dissolved }\end{array}$ \\
\hline \multicolumn{8}{|c|}{ Basin zone -- West-side basin (BW) subzone } \\
\hline \multirow[t]{3}{*}{ 18S/19E- } & $15 \mathrm{~N} 1 \mathrm{M}$ & $5-31-89$ & 6,140 & 7.0 & 610 & 360 & 620 \\
\hline & $21 \mathrm{~N} 3 \mathrm{M}$ & $5-31-89$ & 2,010 & 7.6 & 300 & 40 & 130 \\
\hline & 34N1M & $5-30-89$ & 8,120 & 7.8 & 510 & 140 & 1,500 \\
\hline 19S/19E- & 14R1M & $5-30-89$ & 6,620 & 7.8 & 67 & 51 & 1,400 \\
\hline 20S/19E- & $13 \mathrm{M} 1 \mathrm{M}$ & $6-07-89$ & 40,500 & 7.2 & 220 & 840 & 10,000 \\
\hline \multirow[t]{2}{*}{$25 \mathrm{~S} / 21 \mathrm{E}-$} & 7B3M & $5-09-89$ & 102,000 & 7.4 & 800 & 1,400 & 30,000 \\
\hline & $17 \mathrm{H} 1 \mathrm{M}$ & $6-21-89$ & 36,200 & 6.9 & 900 & 770 & 7,200 \\
\hline \multirow[t]{2}{*}{$26 \mathrm{~S} / 21 \mathrm{E}-$} & 2R1M & $6-21-89$ & 3,170 & 8.0 & 37 & 17 & 630 \\
\hline & 14R1M & $6-29-89$ & 23,100 & 7.7 & 330 & 180 & 5,900 \\
\hline \multirow{2}{*}{$\begin{array}{l}27 \mathrm{~S} / 22 \mathrm{E}- \\
32 \mathrm{~S} / 27 \mathrm{E}-\end{array}$} & 20M1M & $7-12-89$ & 10,400 & 5.6 & 260 & 120 & 2,100 \\
\hline & $7 \mathrm{R} 2 \mathrm{M}$ & $7-19-89$ & 5,930 & 6.8 & 660 & 260 & 550 \\
\hline \multicolumn{8}{|c|}{ Basin zone -- East-side basin (BE) subzone } \\
\hline $19 \mathrm{~S} / 20 \mathrm{E}-$ & 32D1M & $6-07-89$ & 790 & 7.2 & 27 & 12 & 120 \\
\hline $20 \mathrm{~S} / 21 \mathrm{E}-$ & $17 \mathrm{~A} 1 \mathrm{M}$ & 6-26-89 & 5,450 & 7.9 & 14 & 9.6 & 1,400 \\
\hline \multirow{2}{*}{$25 \mathrm{~S} / 21 \mathrm{E}-$} & 12D2M & $7-07-89$ & 16,700 & 7.5 & 160 & 280 & 4,100 \\
\hline & $26 \mathrm{P} 2 \mathrm{M}$ & $6-21-89$ & 43,900 & 8.0 & 68 & 200 & 13,000 \\
\hline \multirow[t]{2}{*}{$25 \mathrm{~S} / 22 \mathrm{E}-$} & $19 \mathrm{~N} 1 \mathrm{M}$ & $7-12-89$ & 1,840 & 7.2 & 89 & 37 & 220 \\
\hline & $34 \mathrm{~A} 2 \mathrm{M}$ & $6-20-89$ & 32,400 & 7.1 & 220 & 300 & 8,500 \\
\hline \multirow[t]{4}{*}{$26 \mathrm{~S} / 22 \mathrm{E}-$} & 7A1M & $7-12-89$ & 1,140 & 6.0 & 65 & 16 & 150 \\
\hline & 20G1M & $6-20-89$ & 1,240 & 6.3 & 71 & 16 & 160 \\
\hline & & $6-20-89$ & 1,240 & 6.3 & 70 & 16 & 160 \\
\hline & $28 \mathrm{R} 2 \mathrm{M}$ & $6-20-89$ & 5,910 & 7.1 & 210 & 42 & 1,000 \\
\hline 26S/23E- & $8 \mathrm{R} 3 \mathrm{M}$ & $6-20-89$ & 2,520 & 7.6 & 21 & 4.0 & 600 \\
\hline \multirow[t]{4}{*}{$27 \mathrm{~S} / 22 \mathrm{E}-$} & 4E2M & $6-21-89$ & 9,840 & 7.7 & 30 & 82 & 2,000 \\
\hline & $15 \mathrm{~A} 2 \mathrm{M}$ & $7-11-89$ & 8,100 & 8.3 & 5.6 & 6.8 & 1,900 \\
\hline & 17R3M & $6-22-89$ & 3,420 & 7.5 & 63 & 29 & 670 \\
\hline & 23D4M & $7-11-89$ & 9,910 & 7.2 & 270 & 200 & 1,600 \\
\hline \multirow[t]{3}{*}{$28 \mathrm{~S} / 22 \mathrm{E}-$} & $5 \mathrm{~A} 1 \mathrm{M}$ & $6-22-89$ & 2,170 & 6.4 & 140 & 12 & 300 \\
\hline & $15 \mathrm{~N} 6 \mathrm{M}$ & $7-12-89$ & 5,210 & 7.1 & 310 & 85 & 670 \\
\hline & & $7-12-89$ & 5,210 & 7.1 & 310 & 85 & 670 \\
\hline 28S/23E- & $3 \mathrm{H} 1 \mathrm{M}$ & $6-22-89$ & 1,980 & 7.1 & 100 & 7.0 & 330 \\
\hline $29 \mathrm{~S} / 24 \mathrm{E}-$ & $5 \mathrm{Q} 1 \mathrm{M}$ & $6-22-89$ & 3,930 & 7.4 & 5.2 & .40 & 1,000 \\
\hline \multirow{2}{*}{$30 \mathrm{~S} / 28 \mathrm{E}-$} & $2 \mathrm{~N} 1 \mathrm{M}$ & $7-18-89$ & 1,480 & 7.6 & 35 & 18 & 270 \\
\hline & & $7-18-89$ & 1,470 & 7.6 & 35 & 18 & 270 \\
\hline $31 \mathrm{~S} / 25 \mathrm{E}-$ & $36 \mathrm{H} 2 \mathrm{M}$ & $6-29-89$ & 2,660 & 7.2 & 600 & 6.0 & 53 \\
\hline \multirow{3}{*}{$31 \mathrm{~S} / 28 \mathrm{E}-$} & $9 \mathrm{C} 1 \mathrm{M}$ & $7-17-89$ & 3,040 & 7.7 & 40 & 32 & 620 \\
\hline & & $7-17-89$ & 3,060 & 7.7 & 39 & 30 & 600 \\
\hline & 22N2M & $6-29-89$ & 727 & 7.6 & 43 & 7.2 & 100 \\
\hline \multirow[t]{2}{*}{$32 \mathrm{~S} / 28 \mathrm{E}-$} & $17 \mathrm{C} 2 \mathrm{M}$ & $7-17-89$ & 3,590 & 7.6 & 260 & 46 & 450 \\
\hline & \multicolumn{7}{|c|}{ Tulare Lake zone -- Northeastern-margin (NEM) subzone } \\
\hline $20 \mathrm{~S} / 20 \mathrm{E}-$ & $15 \mathrm{M} 2 \mathrm{M}$ & $5-25-89$ & 9,680 & 7.3 & 95 & 280 & 2,000 \\
\hline $20 \mathrm{~S} / 21 \mathrm{E}-$ & 19D1M & $5-24-89$ & 9,360 & 8.1 & 19 & 54 & 2,100 \\
\hline $20 \mathrm{~S} / 22 \mathrm{E}-$ & 33R2M & 6-08-89 & 3,200 & 9.2 & 3.1 & 1.1 & 790 \\
\hline 21S/21E- & $2 \mathrm{G} 1 \mathrm{M}$ & $6-08-89$ & 2,160 & 7.6 & 21 & 14 & 450 \\
\hline \multirow[t]{2}{*}{$21 \mathrm{~S} / 22 \mathrm{E}-$} & $16 \mathrm{C} 2 \mathrm{M}$ & $6-26-89$ & 3,760 & 7.6 & 36 & 21 & 780 \\
\hline & 27A3M & $6-09-89$ & 1,340 & 8.3 & 16 & 9.6 & 280 \\
\hline \multirow[t]{2}{*}{$22 \mathrm{~S} / 23 \mathrm{E}-$} & 7R1M & $6-27-89$ & 2,200 & 8.0 & 23 & 13 & 490 \\
\hline & $27 \mathrm{M} 1 \mathrm{M}$ & $6-27-89$ & 2,420 & 7.6 & 64 & 27 & 440 \\
\hline
\end{tabular}




\begin{tabular}{cccccccc}
\hline $\begin{array}{c}\text { Potassium, } \\
\text { dissolved }\end{array}$ & $\begin{array}{c}\text { Bicarbonate } \\
\text { (as } \mathrm{HCO}_{3} \text { ) }\end{array}$ & $\begin{array}{c}\text { Sulfate, } \\
\text { dissolved }\end{array}$ & $\begin{array}{c}\text { Chloride, } \\
\text { dissolved }\end{array}$ & $\begin{array}{c}\text { Fluoride, } \\
\text { dissolved }\end{array}$ & $\begin{array}{c}\text { Bromide, } \\
\text { dissolved }\end{array}$ & $\begin{array}{c}\text { Silica, } \\
\text { dissolved }\end{array}$ & $\begin{array}{c}\text { Solids, } \\
\text { sum of } \\
\text { constituents, } \\
\text { dissolved }\end{array}$ \\
\hline \multicolumn{7}{c}{ Basin zone-- West-side basin (BW) subzone } \\
\hline 1.9 & 444 & 3,400 & 420 & .50 & .40 & 33 & 5,670 \\
.90 & 137 & 790 & 140 & .30 & .44 & 22 & 1,520 \\
2.6 & 400 & 4,400 & 310 & .20 & .49 & 40 & 7,230 \\
1.3 & 300 & 2,900 & 390 & 1.0 & .83 & 31 & 5,080 \\
21 & 495 & 20,000 & 5,900 & .50 & .94 & 23 & 37,300 \\
14 & 185 & 15,000 & 44,000 & .10 & 110 & 16 & 91,900 \\
9.3 & 349 & 5,500 & 11,000 & .50 & 66 & 44 & 25,700 \\
1.4 & 354 & 740 & 340 & .10 & 1.3 & 1 & 1,950 \\
3.9 & 295 & 14,000 & 1,000 & $<.10$ & 1.7 & 52 & 21,700 \\
2.5 & 68 & 4,100 & 1,200 & .40 & 2.7 & 36 & 7,870 \\
8.8 & 338 & 2,500 & 550 & 1.5 & .83 & 29 & 5,140
\end{tabular}

\begin{tabular}{|c|c|c|c|c|c|c|c|}
\hline \multicolumn{8}{|c|}{ Basin zone -- East-side basin (BE) subzone } \\
\hline 2.1 & 80 & 230 & 45 & .70 & .03 & 22 & 502 \\
\hline 2.0 & 2,365 & 440 & 510 & 1.2 & .39 & 25 & 3,570 \\
\hline 1.7 & 849 & 7,200 & 1,600 & 2.9 & 2.3 & 31 & 13,900 \\
\hline 3.3 & 880 & 27,000 & 3,400 & 11 & 15 & 14 & 44,400 \\
\hline 1.4 & 189 & 310 & 310 & .70 & .92 & 33 & 1,100 \\
\hline 1.9 & 805 & 12,000 & 6,300 & 2.2 & 36 & 32 & 27,400 \\
\hline 5.9 & 167 & 250 & 130 & .50 & .35 & 37 & 737 \\
\hline 3.2 & 117 & 190 & 210 & 1.2 & .70 & 21 & 739 \\
\hline 3.3 & 117 & 190 & 210 & 1.2 & .69 & 21 & 739 \\
\hline .40 & 239 & 1,000 & 1,200 & 3.1 & 14 & 56 & 3,770 \\
\hline .80 & 676 & 560 & 130 & 1.4 & .08 & 28 & 1,700 \\
\hline 1.2 & 538 & 1,400 & 2,200 & .80 & 9.9 & 27 & 6,230 \\
\hline .50 & 815 & 2,100 & 1,000 & 3.3 & 2.6 & 38 & 5,500 \\
\hline 2.1 & 490 & 820 & 370 & 5.0 & 0.75 & 28 & 2,240 \\
\hline 2.0 & 371 & 2,100 & 2,200 & 1.6 & 5.1 & 46 & 6,640 \\
\hline 5.8 & 180 & 410 & 350 & .50 & 3.6 & 31 & 1,340 \\
\hline .90 & 449 & 560 & 1,100 & 1.0 & 5.1 & 38 & 3,010 \\
\hline .70 & 449 & 560 & 1,200 & 1.0 & 5.1 & 38 & 3,110 \\
\hline 1.6 & 394 & 420 & 63 & .50 & .24 & 37 & 1,400 \\
\hline .10 & 1,029 & 710 & 310 & 2.5 & 1.5 & 45 & 2,700 \\
\hline 3.0 & 507 & 160 & 110 & .60 & .17 & 54 & 1,010 \\
\hline 3.0 & 507 & 160 & 100 & .70 & .17 & 55 & 999 \\
\hline 2.8 & 216 & 1,500 & 80 & 2.2 & .25 & 35 & 2,420 \\
\hline 2.8 & 748 & 590 & 300 & .60 & .28 & 28 & 2,020 \\
\hline 2.7 & 748 & 590 & 290 & .60 & .40 & 28 & 1,990 \\
\hline 1.5 & 278 & 75 & 42 & .50 & .11 & 27 & 440 \\
\hline 23 & 159 & 940 & 660 & 1.5 & 1.0 & 16 & 2,490 \\
\hline \multicolumn{8}{|c|}{ Tulare Lake zone -- Northeastern-margin (NEM) subzone } \\
\hline 8.1 & 699 & 4,200 & 710 & 1.4 & .78 & 51 & 7,710 \\
\hline 2.6 & 1,305 & 2,300 & 1,300 & 1.2 & 2.1 & 45 & 6,490 \\
\hline .70 & 1,744 & 160 & 100 & 2.3 & $<.01$ & 17 & 2,010 \\
\hline 1.5 & 724 & 260 & 180 & 2.3 & .28 & 32 & 1,320 \\
\hline 2.4 & 835 & 580 & 490 & 2.0 & 1.4 & 13 & 2,360 \\
\hline .60 & 533 & 150 & 69 & 1.2 & .33 & 23 & 850 \\
\hline 1.4 & 1,132 & 130 & 58 & 5.2 & .03 & 21 & 1,400 \\
\hline 1.2 & 436 & 610 & 120 & .30 & .24 & 67 & 1,710 \\
\hline
\end{tabular}


Table 7. Chemical analyses of major ions in water samples from selected wells, Tulare Basin, California--

\begin{tabular}{|c|c|c|c|c|c|c|c|}
\hline State we & No. & Date & $\begin{array}{c}\text { Specific } \\
\text { conductance, } \\
\text { lab } \\
(\mu \mathrm{S} / \mathrm{cm})\end{array}$ & $\begin{array}{c}\mathrm{pH}, \\
\text { field } \\
\text { (standard } \\
\text { units) }\end{array}$ & $\begin{array}{l}\text { Calcium, } \\
\text { dissolved }\end{array}$ & $\begin{array}{c}\text { Magnesium, } \\
\text { dissolved }\end{array}$ & $\begin{array}{l}\text { Sodium, } \\
\text { dissolved }\end{array}$ \\
\hline \multicolumn{8}{|c|}{ Tulare Lake zone -- Southern/Western-margin (SWM) subzone } \\
\hline 20S/19E- & $25 \mathrm{~A} 3 \mathrm{M}$ & $6-07-89$ & 27,600 & 7.2 & 530 & 1,800 & 5,400 \\
\hline \multirow[t]{2}{*}{ 21S/19E- } & 1D3M & $6-07-89$ & 15,500 & 7.4 & 360 & 720 & 3,600 \\
\hline & 16R2M & 6-06-89 & 59,200 & 7.4 & 440 & 1,400 & 18,000 \\
\hline $22 \mathrm{~S} / 19 \mathrm{E}-$ & $28 \mathrm{~J} 1 \mathrm{M}$ & $6-05-89$ & 22,600 & 6.6 & 490 & 990 & 4,200 \\
\hline $23 \mathrm{~S} / 20 \mathrm{E}-$ & 14B1M & $6-28-89$ & 9,410 & 7.5 & 150 & 260 & 1,900 \\
\hline \multirow[t]{4}{*}{$23 \mathrm{~S} / 23 \mathrm{E}-$} & $15 \mathrm{M} 1 \mathrm{M}$ & $6-27-89$ & 56,900 & 6.8 & 600 & 1,500 & 15,000 \\
\hline & & $6-27-89$ & 57,100 & 6.8 & 620 & 1,600 & 15,000 \\
\hline & 26G1M & $6-28-89$ & 32,900 & 7.4 & 300 & 410 & 8,400 \\
\hline & 31D2M & $6-27-89$ & 44,000 & 7.4 & 500 & 940 & 11,000 \\
\hline \multirow[t]{2}{*}{$24 \mathrm{~S} / 23 \mathrm{E}-$} & $4 \mathrm{~K} 1 \mathrm{M}$ & $6-28-89$ & 45,800 & 7.6 & 180 & 600 & 13,000 \\
\hline & \multicolumn{7}{|c|}{ Tulare Lake zone -- Tulare Lake bed (TLB) subzone } \\
\hline \multirow{2}{*}{ 21S/19E- } & $23 \mathrm{~A} 1 \mathrm{M}$ & $6-06-89$ & 18,700 & 6.1 & 480 & 1,300 & 3,300 \\
\hline & 35J1M & $6-06-89$ & 18,000 & 6.0 & 440 & 1,700 & 2,600 \\
\hline \multirow{3}{*}{$21 \mathrm{~S} / 20 \mathrm{E}-$} & 10Q1M & $6-27-89$ & 10,500 & 6.4 & 580 & 990 & 1,000 \\
\hline & $26 \mathrm{D} 1 \mathrm{M}$ & $6-27-89$ & 10,400 & 6.4 & 590 & 520 & 1,400 \\
\hline & 28B1M & $6-27-89$ & 10,800 & 6.3 & 510 & 690 & 1,400 \\
\hline $21 \mathrm{~S} / 22 \mathrm{E}-$ & 19E1M & $6-08-89$ & 8,870 & 6.9 & 470 & 210 & 1,500 \\
\hline \multirow[t]{2}{*}{$22 \mathrm{~S} / 19 \mathrm{E}-$} & $9 \mathrm{H} 1 \mathrm{M}$ & $6-06-89$ & 12,800 & 6.0 & 430 & 510 & 2,200 \\
\hline & $13 \mathrm{~J} 1 \mathrm{M}$ & $6-05-89$ & 12,600 & 6.5 & 530 & 610 & 2,000 \\
\hline \multirow[t]{4}{*}{$22 \mathrm{~S} / 21 \mathrm{E}-$} & 13D1M & $6-28-89$ & 2,210 & 6.6 & 140 & 51 & 260 \\
\hline & 16B1M & $6-28-89$ & 5,800 & 6.2 & 580 & 230 & 660 \\
\hline & 18D2M & $6-27-89$ & 5,840 & 6.2 & 580 & 260 & 670 \\
\hline & 28R1M & $6-28-89$ & 12,400 & 6.8 & 510 & 340 & 2,200 \\
\hline \multirow[t]{5}{*}{$22 \mathrm{~S} / 22 \mathrm{E}-$} & 9N1M & $6-28-89$ & 2,670 & 6.6 & 140 & 48 & 420 \\
\hline & & $6-28-89$ & 2,670 & 6.6 & 140 & 48 & 410 \\
\hline & 14D1M & $6-09-89$ & 1,500 & 7.2 & 44 & 13 & 290 \\
\hline & 22R1M & $6-19-89$ & 3,680 & 7.2 & 140 & 65 & 580 \\
\hline & $35 \mathrm{~N} 1 \mathrm{M}$ & $6-19-89$ & 4,210 & 6.3 & 260 & 94 & 650 \\
\hline 23S/19E- & $2 \mathrm{~A} 1 \mathrm{M}$ & $6-05-89$ & 25,800 & 5.8 & 470 & 1,300 & 5,500 \\
\hline 23S/21E- & 8R1M & $6-28-89$ & 11,400 & 6.6 & 490 & 230 & 2,200 \\
\hline $23 \mathrm{~S} / 22 \mathrm{E}-$ & $6 \mathrm{R} 1 \mathrm{M}$ & $6-19-89$ & 10,500 & 6.6 & 770 & 290 & 1,600 \\
\hline \multirow[t]{2}{*}{$23 \mathrm{~S} / 23 \mathrm{E}-$} & 7M1M & $6-27-89$ & 17,500 & 6.4 & 530 & 500 & 3,300 \\
\hline & & $6-27-89$ & 17,600 & 6.4 & 530 & 510 & 3,400 \\
\hline \multicolumn{8}{|c|}{ Miscellaneous sites } \\
\hline $26 \mathrm{~S} / 22 \mathrm{E}-$ & 34P1M & $6-20-89$ & 14,500 & 7.1 & 570 & 68 & 2,700 \\
\hline \multirow{3}{*}{$27 \mathrm{~S} / 23 \mathrm{E}-$} & $18 \mathrm{~A} 1 \mathrm{M}$ & $7-12-89$ & 1,560 & 7.2 & 100 & 11 & 200 \\
\hline & $20 \mathrm{R} 2 \mathrm{M}$ & $6-29-89$ & 2,120 & 8.1 & 3.6 & .50 & 440 \\
\hline & & $6-29-89$ & 2,130 & 8.1 & 3.7 & .40 & 440 \\
\hline $32 \mathrm{~S} / 28 \mathrm{E}-$ & $30 \mathrm{C} 2 \mathrm{M}$ & $7-18-89$ & 4,790 & 7.6 & 410 & 260 & 460 \\
\hline \multirow[t]{2}{*}{$32 S / 27 \mathrm{E}-$} & $10 \mathrm{~N} 1 \mathrm{M}$ & $6-29-89$ & 1,310 & 7.1 & 140 & 42 & 94 \\
\hline & 16R4M & $6-29-89$ & 3,740 & 6.9 & 540 & 130 & 270 \\
\hline $32 \mathrm{~S} / 28 \mathrm{E}-$ & $18 \mathrm{D} 2 \mathrm{M}$ & $7-18-89$ & 5,190 & 7.4 & 440 & 140 & 700 \\
\hline
\end{tabular}




\begin{tabular}{cccccccc}
\hline $\begin{array}{c}\text { Potassium, } \\
\text { dissolved }\end{array}$ & $\begin{array}{c}\text { Bicarbonate } \\
\left.\text { (as } \mathrm{HCO}_{3}\right)\end{array}$ & $\begin{array}{c}\text { Sulfate, } \\
\text { dissolved }\end{array}$ & $\begin{array}{l}\text { Chloride, } \\
\text { dissolved }\end{array}$ & $\begin{array}{c}\text { Fluoride, } \\
\text { dissolved }\end{array}$ & $\begin{array}{c}\text { Bromide, } \\
\text { dissolved }\end{array}$ & $\begin{array}{c}\text { Solidica, } \\
\text { dissolved }\end{array}$ & $\begin{array}{c}\text { sum of } \\
\text { constituents, } \\
\text { dissolved }\end{array}$ \\
\hline \multicolumn{7}{c}{ Tulare Lake } \\
\hline 17 & 861 & 12,000 & 5,300 & .50 & 4.7 & 25 & 25,500 \\
11 & 423 & 8,400 & 1,400 & .70 & 2.6 & 26 & 14,800 \\
89 & 668 & 34,000 & 9,200 & .80 & 24 & 17 & 63,600 \\
65 & 627 & 8,700 & 4,200 & 0.30 & 7.7 & 44 & 19,200 \\
15 & 1,129 & 3,300 & 940 & 1.0 & 2.4 & 34 & 7,180 \\
10 & 945 & 18,000 & 14,000 & .30 & 30 & 29 & 49,700 \\
11 & 945 & 20,000 & 15,000 & .20 & 32 & 32 & 52,800 \\
31 & 1,293 & 13,000 & 5,100 & .20 & 9.6 & 34 & 28,000 \\
11 & 539 & 17,000 & 9,600 & .50 & 21 & 30 & 39,500 \\
82 & 1,537 & 19,000 & 8,700 & .20 & 21 & 38 & 42,500
\end{tabular}

\begin{tabular}{|c|c|c|c|c|c|c|c|}
\hline \multicolumn{8}{|c|}{ Tulare Lake zone -- Tulare Lake bed (TLB) subzone } \\
\hline 22 & 296 & 11,000 & 2,000 & .30 & 5.2 & 38 & 18,000 \\
\hline 25 & 637 & 12,000 & 1,200 & .30 & 2.2 & 35 & 18,500 \\
\hline 15 & 1,129 & 6,300 & 540 & .20 & 1.2 & 22 & 10,000 \\
\hline 18 & 839 & 4,500 & 1,200 & .60 & 2.8 & 31 & 8,750 \\
\hline 26 & 688 & 5,200 & 1,200 & .70 & 3.4 & 25 & 9,460 \\
\hline 12 & 541 & 3,700 & 990 & .40 & 2.4 & 34 & 7,200 \\
\hline 23 & 234 & 6,700 & 1,000 & .30 & 3.6 & 49 & 11,000 \\
\hline 32 & 1,537 & 4,800 & 1,700 & .20 & 3.8 & 49 & 10,500 \\
\hline 5.9 & 1,000 & 200 & 180 & .20 & .27 & 43 & 1,380 \\
\hline 13 & 588 & 2,900 & 430 & .80 & 1.2 & 53 & 5,220 \\
\hline 20 & 451 & 3,400 & 280 & .90 & 0.58 & 39 & 5,550 \\
\hline 5.5 & 795 & 5,100 & 1,400 & 1.0 & 3.3 & 22 & 9,990 \\
\hline 4.3 & 449 & 920 & 120 & 1.0 & .27 & 22 & 1,900 \\
\hline 4.2 & 449 & 910 & 120 & .90 & .26 & 22 & 1,880 \\
\hline 1.5 & 510 & 220 & 99 & .80 & .22 & 29 & 950 \\
\hline 5.4 & 896 & 300 & 610 & .80 & 2.1 & 38 & 2,190 \\
\hline 7.3 & 315 & 2,100 & 140 & .50 & .24 & 35 & 3,450 \\
\hline 35 & 243 & 13,000 & 3,700 & .10 & 7.8 & 39 & 24,300 \\
\hline 9.0 & 830 & 4,000 & 1,500 & 1.0 & 3.0 & 33 & 8,890 \\
\hline 9.7 & 998 & 3,900 & 1,400 & .40 & 2.0 & 53 & 8,530 \\
\hline 9.8 & 585 & 6,100 & 3,100 & .50 & 6.1 & 34 & 13,900 \\
\hline 9.9 & 585 & 6,200 & 3,100 & .50 & 5.9 & 34 & 14,100 \\
\hline \multicolumn{8}{|c|}{ Miscellaneous sites } \\
\hline 4.2 & 293 & 2,200 & 3,900 & 3.7 & 37 & 66 & 9,740 \\
\hline .50 & 273 & 160 & 180 & .90 & .47 & 38 & 985 \\
\hline .70 & 585 & 190 & 210 & 2.5 & .50 & 52 & 1,250 \\
\hline .60 & 585 & 190 & 210 & 2.4 & .50 & 52 & 1,250 \\
\hline 19 & 90 & 2,400 & 270 & 6.6 & .88 & 17 & 4,260 \\
\hline 1.2 & 444 & 330 & 21 & .80 & .08 & 62 & 938 \\
\hline 26 & 220 & 2,100 & 67 & .90 & . 11 & 48 & 3,370 \\
\hline 12 & 227 & 2,600 & 350 & 5.5 & .23 & 22 & 4,440 \\
\hline
\end{tabular}


Table 8. Chemical analyses of selected trace elements in water samples from selected wells, Tulare Basin,

[State well No.: See well-numbering system on page VI. Results are in micrograms per liter, unless otherwise noted; <,

\begin{tabular}{|c|c|c|c|c|c|c|c|c|}
\hline \multicolumn{2}{|c|}{ State Well No. } & Date & $\begin{array}{l}\text { Aluminum, } \\
\text { dissolved }\end{array}$ & $\begin{array}{l}\text { Arsenic, } \\
\text { dissolved }\end{array}$ & $\begin{array}{c}\text { Barium, } \\
\text { dissolved }\end{array}$ & $\begin{array}{c}\text { Boron, } \\
\text { dissolved }\end{array}$ & $\begin{array}{l}\text { Chromium, } \\
\text { dissolved }\end{array}$ & $\begin{array}{c}\text { Iron, } \\
\text { dissolved }\end{array}$ \\
\hline \multicolumn{9}{|c|}{ Alluvium-fan zone -- West-side alluvium (CR) subzone } \\
\hline \multirow[t]{2}{*}{$25 \mathrm{~S} / 20 \mathrm{E}-$} & $15 \mathrm{~A} 4 \mathrm{M}$ & $7-12-89$ & $<10$ & 1 & 200 & 2,100 & 3 & 30 \\
\hline & 23P1M & $6-21-89$ & $<10$ & 1 & $<100$ & 2,800 & 6 & 20 \\
\hline \multirow{3}{*}{$25 \mathrm{~S} / 21 \mathrm{E}-$} & 29N1M & $6-21-89$ & 10 & 4 & $<100$ & 68,000 & 5 & 60 \\
\hline & $31 \mathrm{P} 1 \mathrm{M}$ & $6-21-89$ & 60 & 3 & $<100$ & 32,000 & $<5$ & 130 \\
\hline & 33N1M & $6-21-89$ & 20 & 3 & $<100$ & 22,000 & $<2$ & 60 \\
\hline \multirow[t]{2}{*}{$26 \mathrm{~S} / 21 \mathrm{E}-$} & $16 \mathrm{R} 1 \mathrm{M}$ & $7-11-89$ & $<10$ & 2 & 200 & 6,900 & 7 & 50 \\
\hline & 36Q1M & $6-20-89$ & $<10$ & 1 & 100 & 19,000 & 2 & 30 \\
\hline $27 \mathrm{~S} / 22 \mathrm{E}-$ & $18 \mathrm{D} 1 \mathrm{M}$ & $6-23-89$ & $<40$ & 6 & 100 & 41,000 & 6 & 130 \\
\hline $29 \mathrm{~S} / 22 \mathrm{E}-$ & $2 \mathrm{C} 1 \mathrm{M}$ & $6-22-89$ & $<10$ & 60 & $<100$ & 3,700 & $<1$ & 20 \\
\hline \multirow{4}{*}{$32 \mathrm{~S} / 25 \mathrm{E}-$} & $12 \mathrm{R} 3 \mathrm{M}$ & $6-29-89$ & 50 & 1 & $<100$ & 73,000 & 20 & 220 \\
\hline & 23B1M & $7-11-89$ & $<10$ & 1 & 100 & 2,100 & 3 & 30 \\
\hline & & $7-11-89$ & $<10$ & 1 & 100 & 2,100 & 3 & 20 \\
\hline & 29D1M & $7-11-89$ & $<10$ & 1 & 100 & 1,600 & 6 & 40 \\
\hline \multirow[t]{4}{*}{$32 \mathrm{~S} / 26 \mathrm{E}-$} & 9R1M & $7-19-89$ & $<10$ & $<2$ & 100 & 2,200 & 4 & 30 \\
\hline & 19D1M & $7-11-89$ & $<10$ & 1 & 100 & 7,400 & 4 & 20 \\
\hline & $22 \mathrm{M} 1 \mathrm{M}$ & $7-18-89$ & 20 & 1 & 100 & 13,000 & 10 & 40 \\
\hline & $25 \mathrm{~K} 1 \mathrm{M}$ & $7-18-89$ & 50 & 1 & 200 & 19,000 & 5 & 60 \\
\hline $32 S / 27 \mathrm{E}-$ & $34 \mathrm{H} 2 \mathrm{M}$ & $7-10-89$ & 70 & 12 & 200 & 5,100 & 3 & 80 \\
\hline $12 \mathrm{~N} / 20 \mathrm{~W}-$ & $32 \mathrm{~K} 1 \mathrm{~S}$ & 6-30-89 & $<10$ & 2 & $<100$ & 3,900 & 10 & 40 \\
\hline $12 \mathrm{~N} / 21 \mathrm{~W}-$ & $34 \mathrm{E} 2 \mathrm{~S}$ & $7-10-89$ & 10 & 1 & 62 & 320 & 3 & $<3$ \\
\hline \multicolumn{9}{|c|}{ Alluivium-fan zone -- East-side alluvium (SN) subzone } \\
\hline 18S/19E- & 9J2M & $5-31-89$ & $<10$ & 3 & $<100$ & 1,300 & $<1$ & 1,400 \\
\hline \multirow[t]{2}{*}{$18 \mathrm{~S} / 20 \mathrm{E}-$} & $15 \mathrm{~A} 2 \mathrm{M}$ & $5-31-89$ & $<10$ & $<1$ & 78 & 70 & 1 & 5 \\
\hline & 31D1M & $5-31-89$ & $<10$ & 2 & 49 & 900 & 3 & 11 \\
\hline $18 \mathrm{~S} / 21 \mathrm{E}-$ & 19D1M & $5-23-89$ & $<10$ & 1 & 110 & 70 & 1 & 6 \\
\hline \multirow[t]{4}{*}{$19 \mathrm{~S} / 20 \mathrm{E}-$} & $5 \mathrm{~A} 1 \mathrm{M}$ & $8-11-89$ & $<10$ & $<1$ & 15 & 100 & $<1$ & 6 \\
\hline & & $8-11-89$ & $<10$ & $<1$ & 15 & 120 & $<1$ & 6 \\
\hline & 11R1M & $6-01-89$ & $<10$ & 2 & 99 & 500 & $<1$ & 7 \\
\hline & 22A2M & $5-31-89$ & $<10$ & 3 & 26 & 130 & 1 & 4 \\
\hline $19 \mathrm{~S} / 20 \mathrm{E}-$ & $35 \mathrm{D} 2 \mathrm{M}$ & $5-25-89$ & $<10$ & 12 & 32 & 70 & 1 & 6 \\
\hline \multirow[t]{2}{*}{$19 \mathrm{~S} / 21 \mathrm{E}-$} & 17R1M & $5-26-89$ & $<10$ & 3 & 60 & 150 & 5 & 6 \\
\hline & $32 \mathrm{~A} 2 \mathrm{M}$ & $5-24-89$ & $<10$ & 3 & 69 & 510 & 2 & 8 \\
\hline \multirow[t]{3}{*}{$20 \mathrm{~S} / 20 \mathrm{E}-$} & 9N1M & $6-01-89$ & $<20$ & 8 & $<100$ & 6,600 & $<2$ & 8,100 \\
\hline & 10D1M & 6-07-89 & 20 & 14 & 100 & 3,800 & $<3$ & 60 \\
\hline & 29D1M & $5-25-89$ & 20 & 6 & $<100$ & 3,500 & 2 & 40 \\
\hline \multirow[t]{2}{*}{$20 \mathrm{~S} / 21 \mathrm{E}-$} & 13B1M & $6-26-89$ & $<10$ & 6 & $<100$ & 1,600 & 2 & $<10$ \\
\hline & 36Q2M & $6-08-89$ & $<10$ & 18 & 100 & 950 & $<1$ & 440 \\
\hline $27 \mathrm{~S} / 23 \mathrm{E}-$ & 11R1M & $6-26-89$ & $<10$ & 87 & 31 & 380 & 1 & 8 \\
\hline $28 \mathrm{~S} / 23 \mathrm{E}-$ & $25 \mathrm{~K} 1 \mathrm{M}$ & $6-22-89$ & 20 & 57 & 9 & 250 & 1 & 16 \\
\hline $30 \mathrm{~S} / 28 \mathrm{E}-$ & 28A4M & $7-17-89$ & 20 & 78 & 56 & 630 & $<1$ & 4 \\
\hline $31 \mathrm{~S} / 28 \mathrm{E}-$ & 21D1M & $6-28-89$ & 10 & 82 & 32 & 710 & 1 & 8 \\
\hline $32 \mathrm{~S} / 27 \mathrm{E}-$ & $2 \mathrm{H} 1 \mathrm{M}$ & $7-19-89$ & 120 & 71 & 200 & 13,000 & 1 & 90 \\
\hline
\end{tabular}




\section{California}

actual value is less than value shown; --, no data]

\begin{tabular}{|c|c|c|c|c|c|c|c|}
\hline $\begin{array}{l}\text { Lithium, } \\
\text { dissolved }\end{array}$ & $\begin{array}{c}\text { Manganese, } \\
\text { dissolved }\end{array}$ & $\begin{array}{l}\text { Mercury, } \\
\text { dissolved }\end{array}$ & $\begin{array}{c}\text { Molybdenum, } \\
\text { dissolved }\end{array}$ & $\begin{array}{c}\text { Nickel, } \\
\text { dissolved }\end{array}$ & $\begin{array}{l}\text { Selenium, } \\
\text { dissolved }\end{array}$ & $\begin{array}{l}\text { Uranium, } \\
\text { dissolved }\end{array}$ & $\begin{array}{l}\text { Vanadium, } \\
\text { dissolved }\end{array}$ \\
\hline \multicolumn{8}{|c|}{ Alluvium-fan zone -- West-side alluvium (CR) subzone } \\
\hline 120 & 10 & $<.1$ & 100 & $<1$ & 8 & 15 & 7 \\
\hline 200 & 10 & $<.1$ & 120 & $<1$ & 13 & 50 & 5 \\
\hline 100 & 20 & .1 & 1,600 & 2 & 20 & 8.5 & 58 \\
\hline 320 & 40 & 6 & 440 & $<2$ & 520 & 34 & 120 \\
\hline 140 & 20 & $<.1$ & 1,000 & $<2$ & 15 & 62 & 55 \\
\hline 300 & 20 & $<.1$ & 56 & $<1$ & $<10$ & 47 & 34 \\
\hline 260 & 710 & $<.1$ & 330 & 12 & $<1$ & 36 & 3 \\
\hline 500 & 40 & $<.1$ & 720 & $<2$ & 27 & 23 & 55 \\
\hline 340 & $<10$ & $<.1$ & 50 & $<1$ & $<1$ & 21 & 73 \\
\hline 210 & 50 & .2 & 1,800 & $<2$ & 58 & 62 & $<100$ \\
\hline 40 & 30 & $<.1$ & 150 & $<1$ & $<1$ & 24 & 3 \\
\hline 40 & 30 & $<.1$ & 120 & $<1$ & $<1$ & 25 & 6 \\
\hline 190 & 200 & $<.1$ & 110 & 5 & 72 & 210 & 10 \\
\hline 70 & $<10$ & $<.1$ & 230 & $<1$ & 2 & 15 & $<1$ \\
\hline 50 & 10 & $<.1$ & 300 & $<1$ & 3 & 43 & 3 \\
\hline 90 & 10 & $<.1$ & 330 & $<1$ & 5 & 42 & 15 \\
\hline 120 & 40 & $<.1$ & 120 & 1 & 260 & 74 & 43 \\
\hline 90 & 330 & $<.1$ & 490 & 4 & $<1$ & 42 & 20 \\
\hline 110 & 10 & $<.1$ & 320 & 2 & 60 & 110 & $<2$ \\
\hline 51 & $<1$ & $<.1$ & 66 & 2 & 1 & 12 & 1 \\
\hline \multicolumn{8}{|c|}{ Alluvium-fan zone -- East-side alluvium (SN) subzone } \\
\hline 20 & 1,700 & $<0.1$ & 170 & $<1$ & $<1$ & 2.8 & 8 \\
\hline 5 & 650 & $<.1$ & 1 & 4 & $<1$ & 2.7 & $<1$ \\
\hline 29 & 10 & $<.1$ & 7 & 7 & 3 & 22 & 12 \\
\hline 6 & 3 & .1 & 18 & 2 & 1 & 42 & $<1$ \\
\hline 6 & 70 & .2 & 8 & 1 & $<1$ & 7.0 & 3 \\
\hline 5 & 70 & .2 & 9 & 2 & $<1$ & 7.4 & 3 \\
\hline$<4$ & 540 & $<.1$ & 360 & 3 & $<1$ & 320 & 13 \\
\hline 11 & 12 & $<.1$ & 6 & 1 & 4 & 57 & 14 \\
\hline$<4$ & 160 & $<.1$ & 4 & 2 & $<1$ & 6.9 & 24 \\
\hline 5 & 15 & $<.1$ & 7 & 2 & $<1$ & 18 & 22 \\
\hline 9 & 270 & $<.1$ & 100 & 7 & 1 & 390 & 17 \\
\hline 60 & 3,100 & $<.1$ & 84 & 14 & $<1$ & 3.2 & 40 \\
\hline 50 & 1,600 & $<.1$ & 820 & 6 & 1 & 99 & 69 \\
\hline 220 & 2,200 & $<.1$ & 120 & 73 & 2 & 17 & 14 \\
\hline 10 & 30 & $<.1$ & 260 & 2 & 1 & - & 26 \\
\hline 30 & 1,200 & $<.1$ & 200 & 1 & $<1$ & 63 & 43 \\
\hline 10 & 280 & $<.1$ & 21 & $<1$ & $<1$ & 15 & 280 \\
\hline 7 & $<1$ & $<.1$ & 11 & 1 & $<1$ & 7.5 & 640 \\
\hline 16 & 130 & $<.1$ & 6 & 1 & $<1$ & 18 & 41 \\
\hline 16 & 2 & $<.1$ & 60 & $<1$ & 1 & 74 & 65 \\
\hline 80 & 320 & $<.1$ & 2,500 & $<1$ & 25 & 2,500 & 94 \\
\hline
\end{tabular}


Table 8. Chemical analyses of selected trace elements in water samples from selected wells, Tulare Basin,

\begin{tabular}{|c|c|c|c|c|c|c|c|c|}
\hline \multicolumn{2}{|c|}{ State Well No. } & Date & $\begin{array}{l}\text { Aluminum, } \\
\text { dissolved }\end{array}$ & $\begin{array}{l}\text { Arsenic, } \\
\text { dissolved }\end{array}$ & $\begin{array}{l}\text { Barium, } \\
\text { dissolved }\end{array}$ & $\begin{array}{c}\text { Boron, } \\
\text { dissolved }\end{array}$ & $\begin{array}{l}\text { Chromium, } \\
\text { dissolved }\end{array}$ & $\begin{array}{c}\text { Iron, } \\
\text { dissolved }\end{array}$ \\
\hline \multicolumn{9}{|c|}{ Basin zone -- West-side basin (BW) subzone } \\
\hline \multirow[t]{3}{*}{ 18S/19E- } & $15 \mathrm{~N} 1 \mathrm{M}$ & $5-31-89$ & $<10$ & 2 & $<100$ & 1,500 & 3 & 20 \\
\hline & $21 \mathrm{~N} 3 \mathrm{M}$ & $5-31-89$ & $<10$ & 1 & 100 & 1,800 & 9 & 20 \\
\hline & $34 \mathrm{~N} 1 \mathrm{M}$ & $5-30-89$ & $<10$ & 13 & $<100$ & 18,000 & 10 & 30 \\
\hline 19S/19E- & 14R1M & $5-30-89$ & 40 & 5 & $<100$ & 9,800 & 4 & 30 \\
\hline 20S/19E- & $13 \mathrm{M} 1 \mathrm{M}$ & 6-07-89 & $<100$ & 5 & 100 & 17,000 & $<5$ & 190 \\
\hline \multirow{2}{*}{$25 \mathrm{~S} / 21 \mathrm{E}-$} & $7 \mathrm{~B} 3 \mathrm{M}$ & $5-09-89$ & $<200$ & 5 & 200 & 61,000 & $<50$ & 780 \\
\hline & 17H1M & $6-21-89$ & 30 & 6 & $<100$ & 36,000 & $<4$ & 180 \\
\hline \multirow{2}{*}{$26 \mathrm{~S} / 21 \mathrm{E}-$} & 2R1M & $6-21-89$ & 20 & 7 & $<100$ & 2,500 & $<1$ & 120 \\
\hline & 14R1M & $6-29-89$ & 30 & 2 & $<100$ & 64,000 & 7 & 100 \\
\hline \multirow{2}{*}{$\begin{array}{l}27 \mathrm{~S} / 22 \mathrm{E}- \\
32 \mathrm{~S} / 27 \mathrm{E}-\end{array}$} & 20M1M & $7-12-89$ & 120 & 2 & 100 & 2,300 & 3 & 850 \\
\hline & 7R2M & 7-19-89 & $<10$ & 2 & 100 & 2,800 & 3 & 40 \\
\hline \multicolumn{9}{|c|}{ Basin zone -- East-side basin (BE) subzone } \\
\hline $19 \mathrm{~S} / 20 \mathrm{E}-$ & 32D1M & $6-07-89$ & 20 & 3 & 17 & 390 & $<1$ & 27 \\
\hline $20 \mathrm{~S} / 21 \mathrm{E}-$ & 17A1M & $6-26-89$ & 10 & 70 & $<100$ & 6,200 & $<1$ & 40 \\
\hline \multirow{2}{*}{$25 \mathrm{~S} / 21 \mathrm{E}-$} & 12D2M & $7-07-89$ & 20 & 20 & 100 & 13,000 & 3 & 50 \\
\hline & $26 \mathrm{P} 2 \mathrm{M}$ & $6-21-89$ & 80 & 12 & $<100$ & 70,000 & $<5$ & 170 \\
\hline \multirow{2}{*}{$25 \mathrm{~S} / 22 \mathrm{E}-$} & 19N1M & $7-12-89$ & $<10$ & 5 & 38 & 800 & $<1$ & 4 \\
\hline & $34 \mathrm{~A} 2 \mathrm{M}$ & $6-20-89$ & $<40$ & 8 & $<100$ & 26,000 & $<4$ & 130 \\
\hline \multirow{4}{*}{$26 \mathrm{~S} / 22 \mathrm{E}-$} & 7A1M & $7-12-89$ & 20 & 9 & 52 & 630 & $<1$ & 1,400 \\
\hline & 20G1M & $6-20-89$ & 30 & 19 & 39 & 580 & $<1$ & 5,200 \\
\hline & & $6-20-89$ & 30 & 22 & 38 & 580 & $<1$ & 5,100 \\
\hline & 28R2M & $6-20-89$ & $<10$ & 29 & $<100$ & 2,800 & 4 & 20 \\
\hline $26 \mathrm{~S} / 23 \mathrm{E}-$ & $8 \mathrm{R} 3 \mathrm{M}$ & $6-20-89$ & 50 & 110 & $<100$ & 740 & 3 & 50 \\
\hline \multirow{4}{*}{$27 \mathrm{~S} / 22 \mathrm{E}-$} & $4 \mathrm{E} 2 \mathrm{M}$ & $6-21-89$ & $<10$ & 14 & $<100$ & 6,100 & $<1$ & 20 \\
\hline & $15 \mathrm{~A} 2 \mathrm{M}$ & $7-11-89$ & 20 & 870 & 100 & 12,000 & 2 & 30 \\
\hline & $17 \mathrm{R} 3 \mathrm{M}$ & $6-22-89$ & $<10$ & 4 & $<100$ & 2,200 & $<1$ & 10 \\
\hline & 23D4M & $7-11-89$ & $<10$ & 41 & 200 & 3,600 & 2 & 40 \\
\hline \multirow{3}{*}{$28 \mathrm{~S} / 22 \mathrm{E}-$} & $5 \mathrm{~A} 1 \mathrm{M}$ & $6-22-89$ & $<10$ & 20 & $<100$ & 1,600 & $<1$ & 10 \\
\hline & $15 \mathrm{~N} 6 \mathrm{M}$ & $7-12-89$ & $<10$ & 18 & 300 & 2,800 & 3 & 20 \\
\hline & & $7-12-89$ & 20 & 17 & 300 & 3,000 & 2 & 30 \\
\hline $28 \mathrm{~S} / 23 \mathrm{E}-$ & $3 \mathrm{H} 1 \mathrm{M}$ & $6-22-89$ & 20 & 3 & 66 & 350 & 20 & 4 \\
\hline 29S/24E- & 5Q1M & $6-22-89$ & 690 & 250 & $<100$ & 2,600 & 7 & 460 \\
\hline \multirow[t]{2}{*}{$30 \mathrm{~S} / 28 \mathrm{E}-$} & $2 \mathrm{~N} 1 \mathrm{M}$ & $7-18-89$ & 30 & 46 & 48 & 1,200 & 2 & 26 \\
\hline & & $7-18-89$ & 40 & 44 & 48 & 1,200 & 2 & 25 \\
\hline $31 \mathrm{~S} / 25 \mathrm{E}-$ & $36 \mathrm{H} 2 \mathrm{M}$ & $6-29-89$ & $<10$ & 1 & $<100$ & 340 & 4 & 40 \\
\hline \multirow{4}{*}{$31 \mathrm{~S} / 28 \mathrm{E}-$} & $9 \mathrm{C} 1 \mathrm{M}$ & $7-17-89$ & 10 & 120 & 100 & 1,200 & $<1$ & 10 \\
\hline & & $7-17-89$ & $<10$ & 100 & 200 & 1,200 & $<1$ & 20 \\
\hline & $22 \mathrm{~N} 2 \mathrm{M}$ & $6-29-89$ & 20 & 10 & 59 & 650 & 3 & 4 \\
\hline & $17 \mathrm{C} 2 \mathrm{M}$ & $7-17-89$ & 10 & 2 & 200 & 520 & 2 & 20 \\
\hline \multicolumn{9}{|c|}{\begin{tabular}{ll}
\multicolumn{3}{c}{ Tulare Lake zone -- Northeastern-margin (NEM) subzone } \\
$5-25-89$ & $<10$
\end{tabular}} \\
\hline $20 \mathrm{~S} / 20 \mathrm{E}-$ & $15 \mathrm{M} 2 \mathrm{M}$ & $5-25-89$ & $<10$ & 10 & $<100$ & 4,200 & 3 & 130 \\
\hline \multirow[t]{2}{*}{$20 \mathrm{~S} / 21 \mathrm{E}-$} & 19D1M & $5-24-89$ & $<10$ & 54 & $<100$ & 4,500 & $<1$ & 20 \\
\hline & 33R2M & 6-08-89 & 40 & 2,600 & 100 & 2,800 & 3 & 20 \\
\hline 21S/21E- & $2 \mathrm{G} 1 \mathrm{M}$ & $6-08-89$ & 10 & 3 & 100 & 1,200 & $<1$ & 520 \\
\hline \multirow{2}{*}{$21 \mathrm{~S} / 22 \mathrm{E}-$} & $16 \mathrm{C} 2 \mathrm{M}$ & $6-26-89$ & 10 & 17 & $<100$ & 1,900 & $<1$ & 20 \\
\hline & $27 \mathrm{~A} 3 \mathrm{M}$ & $6-09-89$ & 10 & 16 & 33 & 370 & $<1$ & 11 \\
\hline \multirow[t]{2}{*}{$22 \mathrm{~S} / 23 \mathrm{E}-$} & 7R1M & $6-27-89$ & 10 & 170 & $<100$ & 2,100 & 3 & $<10$ \\
\hline & 27M1M & $6-27-89$ & $<10$ & 9 & $<100$ & 1,600 & 2 & 10 \\
\hline
\end{tabular}




\begin{tabular}{|c|c|c|c|c|c|c|c|}
\hline $\begin{array}{l}\text { Lithium, } \\
\text { dissolved }\end{array}$ & $\begin{array}{c}\text { Manganese, } \\
\text { dissolved }\end{array}$ & $\begin{array}{l}\text { Mercury, } \\
\text { dissolved }\end{array}$ & $\begin{array}{c}\text { Molybdenum, } \\
\text { dissolved }\end{array}$ & $\begin{array}{c}\text { Nickel, } \\
\text { dissolved }\end{array}$ & $\begin{array}{l}\text { Selenium, } \\
\text { dissolved }\end{array}$ & $\begin{array}{l}\text { Uranium, } \\
\text { dissolved }\end{array}$ & $\begin{array}{l}\text { Vanadium, } \\
\text { dissolved }\end{array}$ \\
\hline \multicolumn{8}{|c|}{ Basin zone -- West-side basin (BW) subzone } \\
\hline 110 & 690 & .1 & 12 & 6 & $<1$ & 17 & 12 \\
\hline 40 & $<10$ & $<.1$ & 30 & 2 & $<1$ & 3.3 & 1 \\
\hline 40 & 40 & $<.1$ & 220 & $<1$ & $<1$ & 100 & 70 \\
\hline 50 & 50 & .1 & 480 & $<1$ & $<1$ & 16 & 31 \\
\hline 170 & 2,000 & $<.1$ & 1,100 & 30 & 3 & 16 & 160 \\
\hline 210 & 240 & $<.1$ & 1,700 & $<1$ & 170 & -- & 1,000 \\
\hline 1,700 & 330 & $<.1$ & 200 & 24 & 21 & 15 & -- \\
\hline 60 & 270 & $<.1$ & 1,000 & 3 & $<1$ & 15 & 32 \\
\hline 240 & 30 & $<.1$ & 1,000 & 2 & 17 & 150 & $<10$ \\
\hline 200 & 1,500 & $<.1$ & 17 & 33 & 10 & 27 & 11 \\
\hline 210 & 370 & $<.1$ & 86 & 10 & ${ }^{1} 240$ & 730 & 17 \\
\hline \multicolumn{8}{|c|}{ Basin zone -- East-side basin (BE) subzone } \\
\hline 4 & 11 & $<.1$ & 37 & 6 & $<1$ & 1.1 & 10 \\
\hline$<10$ & 140 & $<.1$ & 380 & 4 & $<1$ & 150 & 87 \\
\hline 280 & 50 & $<.1$ & 1,500 & $<1$ & 32 & 380 & 50 \\
\hline 160 & 50 & $<.1$ & 12,000 & $<2$ & $<10$ & 960 & 240 \\
\hline 65 & 1,100 & $<.1$ & 27 & 4 & $<1$ & 6.4 & 4 \\
\hline 230 & 40 & .1 & 640 & $<2$ & 14 & 260 & $<100$ \\
\hline 69 & 140 & $<.1$ & 14 & 4 & $<1$ & 2.1 & $<1$ \\
\hline 17 & 420 & $<.1$ & 300 & 10 & $<1$ & 86 & 13 \\
\hline 18 & 410 & $<.1$ & 330 & 13 & $<1$ & 90 & 12 \\
\hline 50 & 10 & $<.1$ & 220 & 1 & $<1$ & 150 & 8 \\
\hline 30 & 20 & $<.1$ & 180 & 2 & 2 & 73 & 300 \\
\hline 130 & $<10$ & .1 & 1,200 & 2 & 3 & 160 & 980 \\
\hline 70 & 10 & $<.1$ & 2,300 & $<1$ & $<1$ & 320 & 330 \\
\hline 80 & 120 & $<.1$ & 700 & $<1$ & $<1$ & 26 & 3 \\
\hline 290 & 360 & $<.1$ & 420 & 2 & 2 & 140 & 33 \\
\hline 50 & 180 & $<.1$ & 120 & 9 & $<1$ & 22 & 15 \\
\hline 200 & 1,300 & $<.1$ & 160 & 3 & $<1$ & 110 & 29 \\
\hline 200 & 1,200 & $<.1$ & 160 & 2 & $<1$ & 110 & 29 \\
\hline 34 & $<1$ & $<0.1$ & 50 & $<1$ & 4 & 55 & 5 \\
\hline 30 & $<10$ & $<.1$ & 100 & 2 & 2 & 40 & 1,200 \\
\hline 30 & 3 & $<.1$ & 38 & 1 & $<1$ & 44 & 36 \\
\hline 30 & 3 & $<.1$ & 37 & 1 & $<1$ & 47 & 37 \\
\hline 80 & 40 & $<.1$ & 68 & 1 & $<1$ & 18 & 1 \\
\hline 20 & 280 & $<.1$ & 120 & $<1$ & 5 & 92 & 39 \\
\hline 20 & 280 & $<.1$ & 110 & $<1$ & 5 & 120 & 38 \\
\hline 7 & 3 & $<.1$ & 34 & $<1$ & 6 & 22 & 6 \\
\hline 60 & 90 & $<.1$ & 64 & $<1$ & 5 & 66 & 11 \\
\hline \multicolumn{8}{|c|}{ Tulare Lake zone -- Northeastern-margin (NEM) subzone } \\
\hline 20 & 640 & $<.1$ & 36 & 2 & $<1$ & 13 & 29 \\
\hline 10 & 80 & .1 & 130 & 11 & 2 & 120 & 180 \\
\hline$<10$ & $<10$ & $<.1$ & 72 & 1 & $<1$ & 33 & 850 \\
\hline$<10$ & 250 & $<.1$ & 86 & 2 & $<1$ & 13 & 16 \\
\hline$<10$ & 200 & $<.1$ & 600 & 1 & 4 & 450 & 53 \\
\hline$<4$ & 73 & $<.1$ & 86 & $<1$ & $<1$ & 47 & 18 \\
\hline 20 & $<10$ & $<.1$ & 160 & 2 & $<1$ & 62 & 180 \\
\hline 70 & 20 & $<.1$ & 20 & $<1$ & $<1$ & 4.3 & 7 \\
\hline
\end{tabular}


Table 8. Chemical analyses of selected trace elements in water samples from selected wells, Tulare Basin,

\begin{tabular}{|c|c|c|c|c|c|c|c|c|}
\hline \multicolumn{2}{|c|}{ State Well No. } & \multirow{2}{*}{$\frac{\text { Date }}{\text { Tula }}$} & \multirow{2}{*}{$\begin{array}{c}\begin{array}{c}\text { Aluminum, } \\
\text { dissolved }\end{array} \\
\text { Lake zone -- }\end{array}$} & $\begin{array}{c}\text { Arsenic, } \\
\text { dissolved }\end{array}$ & $\begin{array}{c}\text { Barium, } \\
\text { dissolved }\end{array}$ & \multirow{2}{*}{$\begin{array}{c}\text { Boron, } \\
\text { dissolved }\end{array}$} & \multirow[t]{2}{*}{$\begin{array}{c}\text { Chromium, } \\
\text { dissolved }\end{array}$} & \multirow[t]{2}{*}{$\begin{array}{c}\text { Iron, } \\
\text { dissolved }\end{array}$} \\
\hline & & & & uthern/Wes & $n-$ margin $(S$ & & & \\
\hline 20S/19E- & $25 \mathrm{~A} 3 \mathrm{M}$ & $6-07-89$ & 20 & 4 & 100 & 20,000 & $<5$ & 130 \\
\hline \multirow{2}{*}{ 21S/19E- } & 1D3M & $6-07-89$ & 20 & 3 & 100 & 10,000 & 6 & 70 \\
\hline & 16R2M & $6-06-89$ & $<100$ & 3 & 100 & 27,000 & $<10$ & 280 \\
\hline 22S/19E- & $28 \mathrm{~J} 1 \mathrm{M}$ & $6-05-89$ & $<50$ & 56 & 100 & 7,300 & $<5$ & 8,200 \\
\hline 23S/20E- & 14B1M & $6-28-89$ & 10 & 10 & $<100$ & 4,900 & 5 & 40 \\
\hline \multirow{4}{*}{ 23S/23E- } & $15 \mathrm{M} 1 \mathrm{M}$ & $6-27-89$ & $<100$ & 110 & $<100$ & 10,000 & $<10$ & 2,000 \\
\hline & & $6-27-89$ & $<100$ & 65 & $<100$ & 11,000 & $<10$ & 2,000 \\
\hline & $26 \mathrm{G} 1 \mathrm{M}$ & $6-28-89$ & $<40$ & 19 & $<100$ & 16,000 & $<4$ & 130 \\
\hline & 31D2M & $6-27-89$ & 90 & 160 & $<100$ & 14,000 & $<5$ & 230 \\
\hline $24 S / 23 E-$ & $4 \mathrm{~K} 1 \mathrm{M}$ & $6-28-89$ & $<50$ & 230 & $<100$ & 19,000 & $<5$ & 220 \\
\hline \multicolumn{9}{|c|}{ Tulare Lake zone -- Tulare Lake bed (TLB) subzone } \\
\hline \multirow{2}{*}{ 21S/19E- } & 23A1M & 6-06-89 & 30 & 44 & 100 & 8,100 & $<3$ & 15,000 \\
\hline & $35 \mathrm{~J} 1 \mathrm{M}$ & 6-06-89 & 20 & 110 & 100 & 5,700 & $<3$ & 210,000 \\
\hline \multirow[t]{3}{*}{$21 \mathrm{~S} / 20 \mathrm{E}-$} & 10Q1M & $6-27-89$ & $<10$ & 72 & $<100$ & 3,400 & $<2$ & 24,000 \\
\hline & 26D1M & $6-27-89$ & 20 & 71 & $<100$ & 3,200 & $<2$ & 48,000 \\
\hline & 28B1M & $6-27-89$ & 20 & 150 & $<100$ & 3,200 & 3 & 52,000 \\
\hline $21 \mathrm{~S} / 22 \mathrm{E}-$ & $19 \mathrm{E} 1 \mathrm{M}$ & $6-08-89$ & $<10$ & 20 & 100 & 2,300 & $<1$ & 6,900 \\
\hline \multirow[t]{2}{*}{ 22S/19E- } & $9 \mathrm{H} 1 \mathrm{M}$ & $6-06-89$ & 20 & 3 & 100 & 6,500 & 3 & 1,500 \\
\hline & $13 \mathrm{~J} 1 \mathrm{M}$ & $6-05-89$ & $<10$ & 20 & 100 & 3,900 & 2 & 18,000 \\
\hline \multirow{4}{*}{$22 \mathrm{~S} / 21 \mathrm{E}-$} & 13D1M & $6-28-89$ & 20 & 15 & $<100$ & 660 & 2 & 4,200 \\
\hline & $16 \mathrm{~B} 1 \mathrm{M}$ & $6-28-89$ & $<10$ & 230 & $<100$ & 2,100 & $<1$ & 42,000 \\
\hline & 18D2M & $6-27-89$ & $<10$ & 40 & $<100$ & 2,100 & 3 & 68,000 \\
\hline & 28R1M & $6-28-89$ & 40 & 8 & $<100$ & 7,400 & 3 & 60 \\
\hline \multirow[t]{5}{*}{$22 \mathrm{~S} / 22 \mathrm{E}-$} & 9N1M & $6-28-89$ & 10 & 8 & $<100$ & 1,200 & 1 & 20 \\
\hline & & $6-28-89$ & $<10$ & 9 & $<100$ & 1,300 & $<1$ & 20 \\
\hline & 14D1M & 6-09-89 & $<10$ & 21 & 47 & 860 & $<1$ & 7 \\
\hline & 22R1M & $6-19-89$ & 10 & 90 & 100 & 1,200 & $<1$ & 110 \\
\hline & $35 \mathrm{~N} 1 \mathrm{M}$ & $6-19-89$ & 20 & 15 & $<100$ & 1,800 & $<1$ & 770 \\
\hline 23S/19E- & $2 \mathrm{~A} 1 \mathrm{M}$ & $6-05-89$ & $<50$ & 4 & 100 & 14,000 & $<5$ & 120 \\
\hline 23S/21E- & 8R1M & $6-28-89$ & 30 & 14 & $<100$ & 6,000 & $<2$ & 3,800 \\
\hline 23S/22E- & 6R1M & $6-19-89$ & 20 & 24 & $<100$ & 2,500 & $<2$ & 3,400 \\
\hline \multirow{2}{*}{$23 \mathrm{~S} / 23 \mathrm{E}-$} & $7 \mathrm{M} 1 \mathrm{M}$ & $6-27-89$ & $<10$ & 17 & 100 & 4,400 & $<2$ & 3,000 \\
\hline & & $6-27-89$ & 20 & 16 & $<100$ & 4,100 & $<2$ & 3,100 \\
\hline \multicolumn{9}{|c|}{ Miscellaneous sites } \\
\hline $26 \mathrm{~S} / 22 \mathrm{E}-$ & 34P1M & $6-20-89$ & 10 & 77 & 100 & 6,900 & 5 & 60 \\
\hline \multirow{3}{*}{$27 \mathrm{~S} / 23 \mathrm{E}-$} & $18 \mathrm{~A} 1 \mathrm{M}$ & $7-12-89$ & 10 & 15 & 48 & 640 & 1 & $<3$ \\
\hline & 20R2M & $6-29-89$ & 50 & 480 & $<100$ & 1,400 & 9 & 20 \\
\hline & & $6-29-89$ & 50 & 490 & $<100$ & 1,400 & 9 & 20 \\
\hline $32 \mathrm{~S} / 28 \mathrm{E}-$ & $30 \mathrm{C} 2 \mathrm{M}$ & $7-18-89$ & 20 & 1 & 200 & 5,500 & 3 & 30 \\
\hline \multirow[t]{2}{*}{$32 S / 27 E-$} & 10N1M & $6-29-89$ & 20 & 68 & 32 & 830 & 1 & 6 \\
\hline & 16R4M & $6-29-89$ & 20 & 4 & $<100$ & 1,400 & 2 & 30 \\
\hline $32 \mathrm{~S} / 28 \mathrm{E}-$ & 18D2M & $7-18-89$ & 10 & 6 & 200 & 3,600 & 2 & 40 \\
\hline
\end{tabular}




\begin{tabular}{|c|c|c|c|c|c|c|c|}
\hline $\begin{array}{l}\text { Lithium, } \\
\text { dissolved }\end{array}$ & $\begin{array}{c}\text { Manganese, } \\
\text { dissolved }\end{array}$ & $\begin{array}{l}\text { Mercury, } \\
\text { dissolved }\end{array}$ & $\begin{array}{c}\text { Molybdenum, } \\
\text { dissolved }\end{array}$ & $\begin{array}{c}\text { Nickel, } \\
\text { dissolved }\end{array}$ & $\begin{array}{l}\text { Selenium, } \\
\text { dissolved }\end{array}$ & $\begin{array}{l}\text { Uranium, } \\
\text { dissolved }\end{array}$ & $\begin{array}{l}\text { Vanadium, } \\
\text { dissolved }\end{array}$ \\
\hline \multicolumn{8}{|c|}{ Tulare Lake zone -- Southern/Western-margin (SWM) subzone } \\
\hline 260 & 1,100 & $<.1$ & 1,600 & 16 & 3 & 160 & 150 \\
\hline 180 & 160 & $<.1$ & 1,300 & 64 & 34 & 38 & 29 \\
\hline 160 & 280 & $<.1$ & 4,200 & 30 & 39 & 37 & 310 \\
\hline 500 & 6,300 & $<.1$ & 480 & 200 & 39 & 31 & 100 \\
\hline 120 & 520 & $<.1$ & 680 & 1 & $<1$ & 500 & 29 \\
\hline 130 & 9,600 & $<.1$ & 2,000 & 12 & $<1$ & 99 & -- \\
\hline 140 & 10,000 & $<.1$ & 2,000 & 16 & $<1$ & 100 & $<250$ \\
\hline 140 & 290 & $<.1$ & 3,500 & $<2$ & $<10$ & 3,100 & 170 \\
\hline 270 & 170 & $<.1$ & 9,800 & 8 & ${ }^{1} 1,000$ & 3,000 & $<100$ \\
\hline 280 & 520 & $<.1$ & 14,000 & $<2$ & ${ }^{1} 350$ & 5,400 & 400 \\
\hline \multicolumn{8}{|c|}{ Tulare Lake zone -- Tulare Lake bed (TLB) subzone } \\
\hline 290 & 6,900 & $<.1$ & 17 & 400 & $<1$ & 1.3 & 29 \\
\hline 400 & 32,000 & $<.1$ & 170 & 400 & $<1$ & 5.2 & 18 \\
\hline 280 & 11,000 & $<.1$ & 25 & 48 & $<1$ & 3.7 & $<5$ \\
\hline 230 & 19,000 & $<.1$ & 110 & 36 & $<1$ & 21 & $<25$ \\
\hline 270 & 14,000 & $<.1$ & 80 & 40 & $<1$ & 1.9 & $<10$ \\
\hline 30 & 4,300 & $<.1$ & 370 & 1 & $<1$ & 11 & 35 \\
\hline 280 & 3,300 & $<.1$ & 22 & 200 & 1 & 2.8 & 23 \\
\hline 320 & 16,000 & $<.1$ & 310 & 34 & 2 & 31 & 31 \\
\hline 40 & 1,800 & $<.1$ & 21 & 1 & $<1$ & 9.2 & 2 \\
\hline 120 & 20,000 & $<.1$ & 47 & 15 & $<1$ & 1.9 & $<5$ \\
\hline 140 & 8,000 & $<.1$ & 64 & 7 & $<1$ & 5.5 & 2 \\
\hline 170 & 7,900 & $<.1$ & 410 & 5 & 2 & 260 & $<25$ \\
\hline 40 & 1,300 & $<.1$ & 220 & 3 & $<1$ & 140 & 5 \\
\hline 40 & 1,300 & $<.1$ & 210 & 4 & $<1$ & 110 & 5 \\
\hline 15 & 540 & $<.1$ & 180 & 6 & $<1$ & 26 & 25 \\
\hline 40 & 2,900 & $<0.1$ & 62 & 2 & $<1$ & 43 & 30 \\
\hline 90 & 3,400 & -- & 320 & 21 & $<1$ & 30 & 8 \\
\hline 370 & 67,000 & $<.1$ & 56 & 300 & 1 & 2.3 & 80 \\
\hline 100 & 7,200 & $<.1$ & 360 & 5 & $<1$ & 350 & $<25$ \\
\hline 90 & 9,600 & $<.1$ & 17 & 7 & $<1$ & 7.4 & 55 \\
\hline 170 & 18,000 & $<.1$ & 190 & 20 & 2 & 130 & $<50$ \\
\hline 170 & 19,000 & $<.1$ & 180 & 20 & 1 & 110 & $<50$ \\
\hline \multicolumn{8}{|c|}{ Miscellaneous sites } \\
\hline 120 & 20 & .2 & 3 & 1 & $<1$ & 390 & 15 \\
\hline 31 & 5 & $<.1$ & 28 & 1 & 3 & 51 & 22 \\
\hline 10 & $<10$ & $<.1$ & 40 & 3 & 2 & 35 & 2,400 \\
\hline 10 & $<10$ & $<.1$ & 38 & 3 & 4 & 35 & 2,400 \\
\hline 70 & 30 & $<.1$ & 350 & $<1$ & 13 & 35 & 13 \\
\hline 100 & 4 & $<.1$ & 16 & 1 & 13 & 79 & 27 \\
\hline 230 & 700 & $<.1$ & 100 & 21 & 1 & 44 & 3 \\
\hline 60 & 440 & $<.1$ & 820 & 2 & 7 & 400 & 27 \\
\hline
\end{tabular}

${ }^{1}$ Wells 23S/23E-31D2M, 24S/23E-4K1M, and 32S/27E-7R2M were resampled on January 5, 1990, to evaluate the reputed selenium concentrations of $1,000,350$, and 240 micrograms per liter, respectively. Selenium concentrations in the January 5,1990 , samples were $1,166,405$, and 251 micrograms per liter, respectively. These analyses were done in the U.S. Geological Survey laboratory in Sacramento, California, using procedures described in Makita and Fujii (1992). 
Table 9. Chemical analyses of nutrients, organic carbon, and stable isotopes in water samples from selected wells, Tulare Basin, California

[State well No.: See well-numbering system on page VI. Results are in milligrams per liter, unless otherwise noted. permil, part per thousand; <, actual value less than value shown; $\mathrm{pCi} / \mathrm{L}$, picocuries per liter; --, no data]

\begin{tabular}{|c|c|c|c|c|c|c|c|c|c|}
\hline State w & ell No. & Date & $\begin{array}{l}\text { Nitrogen, } \\
\text { Nitrite, } \\
\text { dissolved } \\
\text { (as N) }\end{array}$ & $\begin{array}{l}\text { Nitrogen, } \\
\text { nitrite } \\
\text { plus } \\
\text { nitrate, } \\
\text { dissolved } \\
\text { (as N) }\end{array}$ & $\begin{array}{l}\text { Phos- } \\
\text { phorus, } \\
\text { dissolved } \\
\text { (as P) }\end{array}$ & $\begin{array}{l}\text { Carbon, } \\
\text { organic, } \\
\text { dissolved } \\
\text { (as C) }\end{array}$ & $\begin{array}{l}\text { Tritium } \\
(\mathrm{pCi} / \mathrm{L})\end{array}$ & $\begin{array}{c}\text { Delta } \\
\text { deuterium } \\
\text { (permil) }\end{array}$ & $\begin{array}{c}\text { Delta } \\
\text { oxygen-18 } \\
\text { (permil) }\end{array}$ \\
\hline \multicolumn{10}{|c|}{ Alluvium-fan zone -- West-side alluvium (CR) subzone } \\
\hline \multirow{2}{*}{$25 \mathrm{~S} / 20 \mathrm{E}-$} & $15 \mathrm{~A} 4 \mathrm{M}$ & $7-12-89$ & .01 & 1.4 & .03 & 1.5 & 36 & -73.5 & -9.55 \\
\hline & 23P1M & $6-21-89$ & $<.01$ & 17 & .03 & 4.2 & 32 & -76.0 & -9.75 \\
\hline \multirow{3}{*}{$25 \mathrm{~S} / 21 \mathrm{E}-$} & 29N1M & $6-21-89$ & .20 & 15 & .07 & 6.9 & 34 & -62.5 & -7.55 \\
\hline & 31P1M & $6-21-89$ & $<.01$ & 5.5 & .01 & 1.0 & -- & -58.0 & -4.75 \\
\hline & 33N1M & $6-21-89$ & $<.01$ & 3.0 & .07 & 6.4 & 38 & -62.0 & -6.85 \\
\hline \multirow{2}{*}{$26 \mathrm{~S} / 21 \mathrm{E}-$} & 16R1M & $7-11-89$ & $<.01$ & 185 & .06 & 14 & 44 & -52.0 & -3.60 \\
\hline & 36Q1M & $6-20-89$ & $<.01$ & $<.10$ & .02 & 17 & 15 & -54.0 & -6.45 \\
\hline $27 \mathrm{~S} / 22 \mathrm{E}-$ & 18D1M & $6-23-89$ & $<.01$ & .78 & .02 & 1.8 & $<5.7$ & -69.0 & -7.90 \\
\hline $29 \mathrm{~S} / 22 \mathrm{E}-$ & 2C1M & $6-22-89$ & $<.01$ & 16 & .05 & 2.6 & 32 & -79.5 & -10.05 \\
\hline \multirow{4}{*}{$32 \mathrm{~S} / 25 \mathrm{E}-$} & $12 \mathrm{R} 3 \mathrm{M}$ & $6-29-89$ & .02 & 15 & .04 & 15 & 41 & -64.0 & -6.45 \\
\hline & 23B1M & $7-11-89$ & $<.01$ & $<.10$ & $<.01$ & 2.1 & $<5.7$ & -75.5 & -10.00 \\
\hline & & $7-11-89$ & $<.01$ & $<.10$ & .01 & 2.6 & $<5.7$ & -76.5 & -9.95 \\
\hline & 29D1M & $7-11-89$ & .36 & 1.2 & .02 & 8.1 & 51 & -70.5 & -9.15 \\
\hline \multirow{4}{*}{$32 \mathrm{~S} / 26 \mathrm{E}-$} & 9R1M & $7-19-89$ & $<.01$ & 3.7 & $<.01$ & .7 & $<5.7$ & -79.0 & -10.90 \\
\hline & 19D1M & $7-11-89$ & $<.01$ & 1.5 & .01 & 2.7 & 22 & -69.0 & -8.45 \\
\hline & $22 \mathrm{M} 1 \mathrm{M}$ & $7-18-89$ & .05 & 3.1 & .02 & 3.8 & 26 & -71.5 & -9.55 \\
\hline & $25 \mathrm{~K} 1 \mathrm{M}$ & $7-18-89$ & .51 & 19 & .02 & 6.2 & 29 & -76.0 & -9.55 \\
\hline $32 S / 27 \mathrm{E}-$ & $34 \mathrm{H} 2 \mathrm{M}$ & $7-10-89$ & .02 & .54 & .10 & 6.5 & $<5.7$ & -70.5 & -8.90 \\
\hline $12 \mathrm{~N} / 20 \mathrm{~W}-$ & $32 \mathrm{~K} 1 \mathrm{~S}$ & $6-30-89$ & .01 & 47 & .02 & 2.6 & 15 & -64.5 & -8.70 \\
\hline $12 \mathrm{~N} / 21 \mathrm{~W}-$ & $34 \mathrm{E} 2 \mathrm{~S}$ & $7-10-89$ & $<.01$ & 18 & .03 & 10 & 31 & -71.0 & -9.20 \\
\hline \multicolumn{10}{|c|}{ Alluvium-fan zone -- East-side alluvium (SN) subzone } \\
\hline $18 \mathrm{~S} / 19 \mathrm{E}-$ & $9 \mathrm{~J} 2 \mathrm{M}$ & $5-31-89$ & 0.01 & $<0.10$ & 0.02 & 3.5 & 55 & -90.0 & -11.40 \\
\hline \multirow{2}{*}{$18 \mathrm{~S} / 20 \mathrm{E}-$} & $15 \mathrm{~A} 2 \mathrm{M}$ & $5-31-89$ & .01 & 8.2 & .05 & 1.6 & 64 & -88.5 & -12.25 \\
\hline & 31D1M & $5-31-89$ & .02 & 100 & .06 & 7.3 & 31 & -77.5 & -9.95 \\
\hline $18 \mathrm{~S} / 21 \mathrm{E}-$ & 19D1M & 5-23-89 & $<.01$ & 29 & .19 & 2.2 & 69 & -89.0 & -12.20 \\
\hline \multirow{5}{*}{ 19S/20E- } & $5 \mathrm{~A} 1 \mathrm{M}$ & $8-11-89$ & .02 & .47 & .04 & 1.2 & 43 & -94.5 & -13.00 \\
\hline & & $8-11-89$ & .02 & .39 & .04 & 1.1 & 40 & -96.0 & -13.10 \\
\hline & 11R1M & $6-01-89$ & .22 & 4.3 & .59 & 7.3 & -- & -86.5 & -11.50 \\
\hline & $22 \mathrm{~A} 2 \mathrm{M}$ & $5-31-89$ & $<.01$ & 15 & .23 & 3.1 & 79 & -88.5 & -11.65 \\
\hline & 35D2M & $5-25-89$ & $<.01$ & .28 & .28 & 1.8 & 28 & -95.0 & -13.05 \\
\hline \multirow{2}{*}{ 19S/21E- } & 17R1M & $5-26-89$ & $<.01$ & 8.2 & .09 & .9 & 73 & -95.5 & -13.00 \\
\hline & $32 \mathrm{~A} 2 \mathrm{M}$ & $5-24-89$ & .63 & 30 & .29 & 5.4 & 47 & -82.0 & -11.80 \\
\hline \multirow[t]{3}{*}{$20 \mathrm{~S} / 20 \mathrm{E}-$} & $9 \mathrm{~N} 1 \mathrm{M}$ & $6-01-89$ & .01 & .80 & .01 & 14 & 49 & -87.0 & -11.25 \\
\hline & 10D1M & $6-07-89$ & .82 & 5.7 & .27 & 14 & 140 & -88.5 & -11.35 \\
\hline & 29D1M & $5-25-89$ & .18 & 26 & 1.4 & 8.1 & 60 & -84.0 & -10.55 \\
\hline \multirow{2}{*}{$20 \mathrm{~S} / 21 \mathrm{E}-$} & 13B1M & $6-26-89$ & .03 & 39 & .66 & 3.1 & 53 & -83.0 & -10.85 \\
\hline & 36Q2M & $6-08-89$ & .24 & 8.0 & .34 & 8.6 & 31 & -80.0 & -9.70 \\
\hline $27 \mathrm{~S} / 23 \mathrm{E}-$ & 11R1M & $6-26-89$ & $<.01$ & $<.10$ & .13 & 2.4 & 35 & -76.5 & -9.50 \\
\hline 28S/23E- & $25 \mathrm{~K} 1 \mathrm{M}$ & $6-22-89$ & $<.01$ & 1.4 & .12 & .8 & 24 & -73.5 & -9.25 \\
\hline $30 \mathrm{~S} / 28 \mathrm{E}-$ & $28 \mathrm{~A} 4 \mathrm{M}$ & $7-17-89$ & .62 & 26 & .39 & 3.7 & 40 & -75.5 & -10.25 \\
\hline 31S/28E- & 21D1M & $6-28-89$ & .02 & 4.9 & .09 & 1.7 & 30 & -89.5 & -11.50 \\
\hline $32 \mathrm{~S} / 27 \mathrm{E}-$ & $2 \mathrm{H} 1 \mathrm{M}$ & $7-19-89$ & .33 & 8.9 & .11 & 5.5 & 17 & -72.5 & -9.70 \\
\hline
\end{tabular}


Table 9. Chemical analyses of nutrients, organic carbon, and stable isotopes in water samples from selected wells, Tulare Basin, California--Continued

\begin{tabular}{|c|c|c|c|c|c|c|c|c|c|}
\hline State $v$ & ell No. & Date & $\begin{array}{l}\text { Nitrogen, } \\
\text { Nitrite, } \\
\text { dissolved } \\
\text { (as N) }\end{array}$ & $\begin{array}{l}\text { Nitrogen, } \\
\text { nitrite } \\
\text { plus } \\
\text { nitrate, } \\
\text { dissolved } \\
\text { (as } \mathrm{N} \text { ) }\end{array}$ & $\begin{array}{l}\text { Phos- } \\
\text { phorus, } \\
\text { dissolved } \\
\text { (as P) }\end{array}$ & $\begin{array}{l}\text { Carbon, } \\
\text { organic, } \\
\text { dissolved } \\
\text { (as C) }\end{array}$ & $\begin{array}{l}\text { Tritium } \\
(\mathrm{pCi} / \mathrm{L})\end{array}$ & $\begin{array}{c}\text { Delta } \\
\text { deuterium } \\
\text { (permil) }\end{array}$ & $\begin{array}{c}\text { Delta } \\
\text { oxygen-18 } \\
\text { (permil) }\end{array}$ \\
\hline \multicolumn{10}{|c|}{ Basin zone -- West-side basin (BW) subzone } \\
\hline \multirow{3}{*}{ 18S/19E- } & $15 \mathrm{~N} 1 \mathrm{M}$ & 5-31-89 & .02 & .50 & .03 & 3.2 & 11 & -87.0 & -10.70 \\
\hline & $21 \mathrm{~N} 3 \mathrm{M}$ & $5-31-89$ & $<.01$ & 5.6 & .07 & 2.1 & 31 & -70.5 & -8.75 \\
\hline & $34 \mathrm{~N} 1 \mathrm{M}$ & $5-30-89$ & .49 & 25 & .26 & 5.1 & 31 & -75.5 & -9.35 \\
\hline 19S/19E- & 14R1M & $5-30-89$ & .08 & 19 & .10 & 2.6 & 27 & -69.0 & -8.55 \\
\hline 20S/19E- & $13 \mathrm{M} 1 \mathrm{M}$ & 6-07-89 & .09 & 3.0 & .48 & 8.6 & 24 & -65.0 & -7.10 \\
\hline \multirow[t]{2}{*}{$25 \mathrm{~S} / 21 \mathrm{E}-$} & $7 \mathrm{~B} 3 \mathrm{M}$ & $5-09-89$ & .14 & 95 & ${ }^{1} .31$ & -- & $<5.7$ & -38.0 & -0.10 \\
\hline & 17H1M & $6-21-89$ & .01 & .30 & .06 & 4.2 & $<5.7$ & -67.0 & -7.65 \\
\hline \multirow[t]{2}{*}{$26 \mathrm{~S} / 21 \mathrm{E}-$} & 2R1M & $6-21-89$ & .04 & .33 & .12 & 1.3 & $<5.7$ & -62.5 & -5.35 \\
\hline & 14R1M & $6-29-89$ & $<.01$ & 14 & .08 & 9.5 & 37 & -60.0 & -6.70 \\
\hline 27S/22E- & 20M1M & $7-12-89$ & 0.46 & 2.2 & 0.01 & 5.0 & 47 & -64.0 & -8.05 \\
\hline $32 \mathrm{~S} / 27 \mathrm{E}-$ & $7 \mathrm{R} 2 \mathrm{M}$ & $7-19-89$ & .22 & 92 & .02 & 7.2 & 30 & -78.5 & -10.20 \\
\hline \multicolumn{10}{|c|}{ Basin zone -- East-side basin (BE) subzone } \\
\hline $19 \mathrm{~S} / 20 \mathrm{E}-$ & 32D1M & $6-07-89$ & .02 & .61 & .36 & 2.5 & 34 & -94.5 & -11.65 \\
\hline $20 \mathrm{~S} / 21 \mathrm{E}-$ & 17A1M & $6-26-89$ & .02 & $<.10$ & 9.2 & 22 & $<5.7$ & -93.0 & -11.85 \\
\hline \multirow[t]{2}{*}{$25 \mathrm{~S} / 21 \mathrm{E}-$} & 12D2M & $7-07-89$ & .03 & 12 & .28 & 6.6 & 29 & -66.0 & -6.65 \\
\hline & $26 \mathrm{P} 2 \mathrm{M}$ & $6-21-89$ & $<.01$ & 36 & .25 & 16 & 25 & -59.5 & -5.65 \\
\hline \multirow[t]{2}{*}{$25 \mathrm{~S} / 22 \mathrm{E}-$} & $19 \mathrm{~N} 1 \mathrm{M}$ & $7-12-89$ & .01 & $<.10$ & .08 & 2.5 & 34 & -71.5 & -8.60 \\
\hline & $34 \mathrm{~A} 2 \mathrm{M}$ & $6-20-89$ & $<.01$ & 2.3 & .15 & 9.2 & 45 & -66.5 & -7.85 \\
\hline \multirow{4}{*}{$26 \mathrm{~S} / 22 \mathrm{E}-$} & 7A1M & $7-12-89$ & $<.01$ & $<.10$ & .04 & 4.3 & 54 & -79.0 & -9.70 \\
\hline & 20G1M & $6-20-89$ & $<.01$ & .49 & $<.01$ & 3.3 & 26 & -75.0 & -9.20 \\
\hline & & $6-20-89$ & $<.01$ & .50 & $<.01$ & 3.4 & 20 & -73.5 & -9.15 \\
\hline & 28R2M & $6-20-89$ & $<.01$ & 29. & .02 & 2.4 & 15 & -76.0 & -9.70 \\
\hline $26 \mathrm{~S} / 23 \mathrm{E}-$ & $8 \mathrm{R} 3 \mathrm{M}$ & $6-20-89$ & .02 & 4.4 & .17 & 3.9 & 10 & -65.0 & -8.55 \\
\hline \multirow{4}{*}{$27 \mathrm{~S} / 22 \mathrm{E}-$} & $4 \mathrm{E} 2 \mathrm{M}$ & $6-21-89$ & $<.01$ & 46. & .30 & 1.9 & 20 & -75.0 & -9.10 \\
\hline & $15 \mathrm{~A} 2 \mathrm{M}$ & $7-11-89$ & .41 & 19. & 1.5 & 8.0 & 44 & -71.0 & -8.40 \\
\hline & 17R3M & $6-22-89$ & .02 & 2.1 & .17 & 1.5 & 16 & -74.0 & -9.45 \\
\hline & 23D4M & $7-11-89$ & .11 & 5.8 & .10 & 4.8 & 84 & -76.5 & -9.75 \\
\hline \multirow[t]{3}{*}{$28 \mathrm{~S} / 22 \mathrm{E}-$} & $5 \mathrm{~A} 1 \mathrm{M}$ & $6-22-89$ & $<.01$ & $<.10$ & .24 & 2.6 & 68 & -85.0 & -10.95 \\
\hline & $15 \mathrm{~N} 6 \mathrm{M}$ & $7-12-89$ & $<.01$ & 3.4 & .21 & 3.5 & 29 & -80.0 & -10.00 \\
\hline & & $7-12-89$ & $<.01$ & 3.4 & .22 & 3.4 & 21 & -79.0 & -10.10 \\
\hline $28 \mathrm{~S} / 23 \mathrm{E}-$ & 3H1M & $6-22-89$ & $<.01$ & 56 & .03 & 2.2 & $<5.7$ & -65.5 & -8.50 \\
\hline $29 \mathrm{~S} / 24 \mathrm{E}-$ & $5 \mathrm{Q} 1 \mathrm{M}$ & $6-22-89$ & $<.01$ & 27 & 1.5 & 5.1 & 23 & -73.5 & -8.95 \\
\hline \multirow[t]{2}{*}{$30 \mathrm{~S} / 28 \mathrm{E}-$} & $2 \mathrm{~N} 1 \mathrm{M}$ & $7-18-89$ & $<.01$ & 24 & .05 & 2.4 & 28 & -89.0 & -11.85 \\
\hline & & $7-18-89$ & $<.01$ & 24 & .05 & 2.3 & 32 & -91.5 & -11.90 \\
\hline $31 \mathrm{~S} / 25 \mathrm{E}-$ & $36 \mathrm{H} 2 \mathrm{M}$ & $6-29-89$ & .08 & 6.6 & .04 & 1.1 & 23 & -67.5 & -8.45 \\
\hline \multirow[t]{3}{*}{$31 \mathrm{~S} / 28 \mathrm{E}-$} & $9 \mathrm{C} 1 \mathrm{M}$ & $7-17-89$ & .09 & 9.0 & .19 & 2.4 & 38 & -87.0 & -11.40 \\
\hline & & $7-17-89$ & .09 & 9.0 & .19 & 3.0 & 31 & -89.5 & -11.35 \\
\hline & $22 \mathrm{~N} 2 \mathrm{M}$ & $6-29-89$ & .01 & .75 & .06 & .8 & 30 & -92.5 & -12.10 \\
\hline $32 \mathrm{~S} / 28 \mathrm{E}-$ & $17 \mathrm{C} 2 \mathrm{M}$ & $7-17-89$ & .15 & 2.2 & .02 & 3.2 & $<5.7$ & -69.5 & -9.95 \\
\hline
\end{tabular}


Table 9. Chemical analyses of nutrients, organic carbon, and stable isotopes in water samples from selected wells, Tulare Basin, California--Continued

\begin{tabular}{|c|c|c|c|c|c|c|c|c|c|}
\hline State we & ell No. & Date & $\begin{array}{l}\text { Nitrogen, } \\
\text { Nitrite, } \\
\text { dissolved } \\
\text { (as N) }\end{array}$ & $\begin{array}{l}\text { Nitrogen, } \\
\text { nitrite } \\
\text { plus } \\
\text { nitrate, } \\
\text { dissolved } \\
\text { (as } \mathrm{N} \text { ) }\end{array}$ & $\begin{array}{l}\text { Phos- } \\
\text { phorus, } \\
\text { dissolved } \\
\text { (as P) }\end{array}$ & $\begin{array}{l}\text { Carbon, } \\
\text { organic, } \\
\text { dissolved } \\
\text { (as C) }\end{array}$ & $\begin{array}{l}\text { Tritium } \\
(\mathrm{pCi} / \mathrm{L})\end{array}$ & $\begin{array}{c}\text { Delta } \\
\text { deuterium } \\
\text { (permil) }\end{array}$ & $\begin{array}{c}\text { Delta } \\
\text { oxygen-18 } \\
\text { (permil) }\end{array}$ \\
\hline \multicolumn{10}{|c|}{ Tulare Lake zone -- Northeastern-margin (NEM) subzone } \\
\hline $20 \mathrm{~S} / 20 \mathrm{E}-$ & 15M2M & $5-25-89$ & .22 & 3.9 & 2.3 & 15 & 24 & -89.0 & -11.25 \\
\hline 20S/21E- & 19D1M & $5-24-89$ & .37 & 18 & 2.4 & 16 & 84 & -83.5 & -10.90 \\
\hline $20 \mathrm{~S} / 22 \mathrm{E}-$ & $33 \mathrm{R} 2 \mathrm{M}$ & $6-08-89$ & .03 & 17 & .16 & 13 & 37 & -81.5 & -11.00 \\
\hline $21 \mathrm{~S} / 21 \mathrm{E}-$ & $2 \mathrm{G} 1 \mathrm{M}$ & $6-08-89$ & $<.01$ & .14 & .06 & 10 & 15 & -76.0 & -9.65 \\
\hline \multirow{2}{*}{$21 \mathrm{~S} / 22 \mathrm{E}-$} & $16 \mathrm{C} 2 \mathrm{M}$ & $6-26-89$ & .54 & 5.3 & .75 & 7.0 & 83 & -83.0 & -10.85 \\
\hline & 27A3M & $6-09-89$ & .05 & 7.5 & .31 & 6.2 & 75 & -83.5 & -10.85 \\
\hline \multirow{2}{*}{ 22S/23E- } & 7R1M & $6-27-89$ & .29 & 23 & 1.5 & 4.6 & 110 & -77.0 & -10.25 \\
\hline & $27 \mathrm{M} 1 \mathrm{M}$ & $6-27-89$ & .02 & 37 & .06 & 3.3 & 20 & -62.5 & -7.60 \\
\hline \multicolumn{10}{|c|}{ Tulare Lake zone -- Southern/Western-margin (SWM) subzone } \\
\hline 21S/19E- & $1 \mathrm{D} 3 \mathrm{M}$ & $6-07-89$ & .22 & 23 & .08 & 8.3 & 27 & -68.0 & -8.00 \\
\hline \multirow[t]{2}{*}{$21 \mathrm{~S} / 19 \mathrm{E}-$} & $16 \mathrm{R} 2 \mathrm{M}$ & $6-06-89$ & .21 & 20 & .47 & 17 & 8.0 & -55.5 & -5.10 \\
\hline & $28 \mathrm{~J} 1 \mathrm{M}$ & $6-05-89$ & .10 & 23 & .03 & 21 & 34 & -57.0 & -5.40 \\
\hline $23 \mathrm{~S} / 20 \mathrm{E}-$ & 14B1M & $6-28-89$ & .06 & 3.4 & .68 & 12 & 13 & -57.5 & -5.30 \\
\hline \multirow[t]{4}{*}{$23 \mathrm{~S} / 23 \mathrm{E}-$} & $15 \mathrm{M} 1 \mathrm{M}$ & $6-27-89$ & .02 & .26 & .34 & 69 & $<5.7$ & -41.5 & -1.75 \\
\hline & & $6-27-89$ & .02 & .13 & .71 & 98 & $<5.7$ & -39.5 & -1.75 \\
\hline & 26G1M & $6-28-89$ & .06 & 17 & .46 & 39 & 9.0 & -53.0 & -5.60 \\
\hline & 31D2M & $6-27-89$ & .98 & 26 & .38 & 75 & $<5.7$ & -40.0 & -2.00 \\
\hline $24 \mathrm{~S} / 23 \mathrm{E}-$ & $4 \mathrm{~K} 1 \mathrm{M}$ & $6-28-89$ & .26 & 27 & 1.7 & 69 & 7.0 & -55.0 & -4.60 \\
\hline \multicolumn{10}{|c|}{ Tulare Lake zone -- Tulare Lake bed margin (TLB) subzone } \\
\hline \multirow[t]{2}{*}{ 21S/19E- } & 23A1M & $6-06-89$ & .02 & $<.10$ & .24 & 14 & 45 & -59.0 & -5.80 \\
\hline & $35 \mathrm{~J} 1 \mathrm{M}$ & $6-06-89$ & .03 & .12 & .01 & 31 & 14 & -57.5 & -4.65 \\
\hline \multirow[t]{3}{*}{$21 \mathrm{~S} / 20 \mathrm{E}-$} & 10Q1M & $6-27-89$ & $<.01$ & $<.10$ & .08 & 13 & $<5.7$ & -60.5 & -5.90 \\
\hline & $26 \mathrm{D} 1 \mathrm{M}$ & $6-27-89$ & .01 & .19 & $<.01$ & 45 & 25 & -66.5 & -6.70 \\
\hline & 28B1M & $6-27-89$ & $<.01$ & $<.10$ & .06 & 39 & 27 & -59.5 & -6.75 \\
\hline 21S/22E- & 19E1M & $6-08-89$ & $<.01$ & $<.10$ & .04 & 14 & 53 & -75.0 & -8.85 \\
\hline \multirow[t]{2}{*}{$22 \mathrm{~S} / 19 \mathrm{E}-$} & 9H1M & $6-06-89$ & .08 & 1.3 & .21 & 11 & 39 & -63.0 & -6.05 \\
\hline & $13 \mathrm{~J} 1 \mathrm{M}$ & $6-05-89$ & .03 & .76 & .08 & 39 & 13 & -59.0 & -4.90 \\
\hline \multirow[t]{4}{*}{$22 \mathrm{~S} / 21 \mathrm{E}-$} & 13D1M & $6-28-89$ & $<.01$ & $<.10$ & .63 & 8.6 & 63 & -68.0 & -8.00 \\
\hline & 16B1M & $6-28-89$ & $<0.01$ & $<0.10$ & $<0.01$ & 18 & 50 & -73.0 & -8.80 \\
\hline & 18D2M & $6-27-89$ & .02 & $<.10$ & .02 & 17 & 25 & -71.5 & -8.05 \\
\hline & 28R1M & $6-28-89$ & $<.01$ & $<.10$ & .95 & 20 & 17 & -54.0 & -4.45 \\
\hline \multirow[t]{5}{*}{$22 \mathrm{~S} / 22 \mathrm{E}-$} & 9N1M & $6-28-89$ & $<.01$ & $<.10$ & .66 & 6.3 & 65 & -68.0 & -7.60 \\
\hline & & $6-28-89$ & $<.01$ & $<.10$ & .68 & 6.5 & 56 & -69.0 & -7.40 \\
\hline & 14D1M & $6-09-89$ & $<.01$ & $<.10$ & .86 & 5.2 & 32 & -76.5 & -8.85 \\
\hline & 22R1M & $6-19-89$ & $<.01$ & $<.10$ & 1.3 & 10 & 100 & -74.0 & -9.05 \\
\hline & $35 \mathrm{~N} 1 \mathrm{M}$ & $6-19-89$ & .02 & .46 & .20 & 11 & 35 & -74.5 & -8.60 \\
\hline 23S/19E- & $2 \mathrm{~A} 1 \mathrm{M}$ & $6-05-89$ & $<.01$ & $<.10$ & .23 & 38 & 43 & -55.5 & -4.95 \\
\hline 23S/21E- & 8R1M & $6-28-89$ & $<.01$ & $<.10$ & .34 & 20 & 13 & -60.0 & -5.55 \\
\hline $23 \mathrm{~S} / 22 \mathrm{E}-$ & 6R1M & $6-19-89$ & .01 & .58 & .38 & 44 & 8.0 & -49.5 & -3.70 \\
\hline \multirow[t]{2}{*}{$23 \mathrm{~S} / 23 \mathrm{E}-$} & $7 \mathrm{M} 1 \mathrm{M}$ & $6-27-89$ & .01 & .32 & .06 & 33 & $<5.7$ & -47.5 & -4.10 \\
\hline & & $6-27-89$ & $<.01$ & .12 & .11 & 34 & $<5.7$ & -48.0 & -4.10 \\
\hline
\end{tabular}


Table 9. Chemical analyses of nutrients, organic carbon, and stable isotopes in water samples from selected wells, Tulare Basin, California--Continued

\begin{tabular}{|c|c|c|c|c|c|c|c|c|c|}
\hline \multicolumn{2}{|c|}{ State well No. } & \multirow[t]{2}{*}{ Date } & $\begin{array}{l}\text { Nitrogen, } \\
\text { Nitrite, } \\
\text { dissolved } \\
\text { (as } \mathrm{N})\end{array}$ & $\begin{array}{l}\text { Nitrogen, } \\
\text { nitrite } \\
\text { plus } \\
\text { nitrate, } \\
\text { dissolved } \\
\text { (as } \mathrm{N} \text { ) } \\
\end{array}$ & $\begin{array}{l}\text { Phos- } \\
\text { phorus, } \\
\text { dissolved } \\
\text { (as P) }\end{array}$ & \multirow[t]{2}{*}{$\begin{array}{l}\text { Carbon, } \\
\text { organic, } \\
\text { dissolved } \\
\text { (as C) }\end{array}$} & \multirow[t]{2}{*}{$\begin{array}{l}\text { Tritium } \\
(\mathrm{pCi} / \mathrm{L})\end{array}$} & \multirow[t]{2}{*}{$\begin{array}{c}\text { Delta } \\
\text { deuterium } \\
\text { (permil) }\end{array}$} & \multirow[t]{2}{*}{$\begin{array}{c}\text { Delta } \\
\text { oxygen-18 } \\
\text { (permil) }\end{array}$} \\
\hline \multicolumn{5}{|c|}{ Miscellaneous sites } & & & & & \\
\hline \multirow{4}{*}{$\begin{array}{l}26 \mathrm{~S} / 22 \mathrm{E}- \\
27 \mathrm{~S} / 23 \mathrm{E}-\end{array}$} & 34P1M & $6-20-89$ & $<.01$ & 9.4 & .03 & 4.3 & $<5.7$ & -77.0 & -9.75 \\
\hline & 18A1M & $7-12-89$ & $<.01$ & 36 & .04 & 2.9 & 34 & -71.5 & -9.10 \\
\hline & 20R2M & $6-29-89$ & $<.01$ & 13 & .57 & 3.5 & 32 & -72.0 & -8.95 \\
\hline & & $6-29-89$ & $<.01$ & 13 & .57 & 3.5 & 28 & -72.0 & -8.95 \\
\hline $32 \mathrm{~S} / 28 \mathrm{E}-$ & $30 \mathrm{C} 2 \mathrm{M}$ & $7-18-89$ & .15 & 82 & .01 & 4.2 & 22 & -61.0 & -7.60 \\
\hline \multirow[t]{2}{*}{$32 S / 27 E-$} & $10 \mathrm{~N} 1 \mathrm{M}$ & $6-29-89$ & .01 & 5.9 & .19 & 1.1 & 23 & -- & - \\
\hline & $16 \mathrm{R} 4 \mathrm{M}$ & $6-29-89$ & .05 & 18 & .07 & 7.6 & $<5.7$ & -70.0 & -9.30 \\
\hline $32 \mathrm{~S} / 28 \mathrm{E}-$ & 18D2M & $7-18-89$ & .15 & 11 & .05 & 9.8 & 15 & -71.0 & -9.70 \\
\hline
\end{tabular}


U.S. DEPARTMENT OF THE INTERIOR

Geological Survey, Room W-2233

2800 Cottage Way, Federal Building

Sacramento, CA 95825

OFFICIAL BUSINESS 